NBER WORKING PAPER SERIES

\title{
WORKPLACE HETEROGENEITY AND THE RISE OF WEST GERMAN WAGE INEQUALITY
}

David Card

Jörg Heining

Patrick Kline

Working Paper 18522

http://www.nber.org/papers/w18522

\author{
NATIONAL BUREAU OF ECONOMIC RESEARCH \\ 1050 Massachusetts Avenue \\ Cambridge, MA 02138 \\ November 2012
}

We are grateful to the IAB and to Stefan Bender for assistance in making this project possible, to Karl Schmidt, Robert Jentsch, Cerstin Erler, and Ali Athmani for invaluable programming help, and to the Berkeley Center for Equitable Growth for funding support. We also thank Christian Dustmann, Bernd Fitzenberger, and seminar participants at EUI Florence, Yale, and the NBER Labor Studies meetings for many helpful comments and suggestions. Robert Heimbach, Hedvig Horvath, and Michele Weynandt provided excellent research assistance. The views expressed herein are those of the authors and do not necessarily reflect the views of the National Bureau of Economic Research.

NBER working papers are circulated for discussion and comment purposes. They have not been peerreviewed or been subject to the review by the NBER Board of Directors that accompanies official NBER publications.

(C) 2012 by David Card, Jörg Heining, and Patrick Kline. All rights reserved. Short sections of text, not to exceed two paragraphs, may be quoted without explicit permission provided that full credit, including (C) notice, is given to the source. 
Workplace Heterogeneity and the Rise of West German Wage Inequality

David Card, Jörg Heining, and Patrick Kline

NBER Working Paper No. 18522

November 2012

JEL No. J01,J3,J4

\begin{abstract}
$\underline{\text { ABSTRACT }}$
We study the role of establishment-specific wage premiums in generating recent increases in West German wage inequality. Models with additive fixed effects for workers and establishments are fit in four distinct time intervals spanning the period 1985-2009. Unlike standard wage models, specifications with both worker and plant-level heterogeneity components can explain the vast majority of the rise in wage inequality. Our estimates suggest that the increasing variability of West German wages results from a combination of rising heterogeneity between workers, rising variability in the wage premiums at different establishments, and increasing assortativeness in the matching of workers to plants. We use the models to decompose changes in wage gaps between different education levels, occupations, and industries, and in all three cases find a growing contribution of plant heterogeneity and rising assortativeness between workers and establishments.
\end{abstract}

David Card

Department of Economics

549 Evans Hall, \#3880

University of California, Berkeley

Berkeley, CA 94720-3880

and NBER

card@econ.berkeley.edu

Jörg Heining

Institute for Employment Research (IAB)

Joerg.Heining@iab.de
Patrick Kline

Department of Economics

UC, Berkeley

508-1 Evans Hall \#3880

Berkeley, CA 94720

and NBER

pkline@econ.berkeley.edu 


\section{Introduction}

Many of the world's developed economies have experienced dramatic increases in wage inequality in recent decades (see Katz and Autor, 1999; and Acemoglu and Autor, 2011 for detailed reviews). While the timing varies from country to country, in each case there was a widening of wage differentials between observable skill groups (e.g., age and education groups), coupled with a rise in within-group inequality. The standard framework for analyzing these changes focuses on shifts in supply and demand for different skill groups (e.g., Katz and Murphy, 1992; Bound and Johnson, 1992; Juhn, Murphy and Pierce, 1993; Goldin and Katz, 2008), mediated by institutional factors like minimum wages and unions (e.g., DiNardo, Fortin, and Lemieux, 1996). Using a variety of data sources, researchers have concluded that supply, demand, and institutions have all contributed to trends in wage inequality, albeit with different magnitudes in different countries and time periods (Freeman and Katz, 1994; Katz and Autor, 1999).

Although most studies focus on the causes of rising wage inequality between workers with different skills, economists have long recognized that employer heterogeneity may generate wage variation among workers with identical skills, even within narrowly defined economic sectors (Slichter, 1950; Reynolds, 1951; Lester, 1967; Rees and Schultz, 1970). There are large differences in productivity across firms and plants (Bernard, Eaton, Jensen, Kortum, 2003; Bloom and Van Reenen, 2007; Foster, Haltiwanger, and Syverson, 2008; Hseih and Klenow, 2009). Modern search-theoretic models with realistic frictions suggest that such differences will lead to an employer-specific component of wage inequality among otherwise identical workers (see e.g., Lentz and Mortensen, 2010). Likewise, an earlier generation of studies argued that employers can offer efficiency wages to reduce shirking and boost morale (Akerlof, 1982; Shapiro and Stiglitz, 1984; Krueger and Summers, 1988; Katz and Summers, 1989). And, in a tradition dating back to Adam Smith, economists have argued that workplace-specific disamenities like longer hours or more strenuous effort will lead to compensating wage differences across jobs (e.g., Brown, 1980).

The magnitude of this workplace component of wage inequality is explored in a number of recent papers that utilize matched employer-employee datasets (Abowd, Kramarz, and Margolis, 1999; Goux and Maurin, 1999; Abowd, Creecy, and Kramarz, 2002; Gruetter and Lalive, 2009). ${ }^{1}$ Virtually all these studies find a significant employer-specific wage component. To date, however, little evidence exists on whether this component has become larger over time, and if so whether such changes can explain some of the trend in cross-sectional

\footnotetext{
${ }^{1}$ An earlier generation of studies (e.g., Davis and Haltiwanger, 1991; Groshen, 1991; Bernard and Jensen, 1995) documented substantial between-plant variation in wages but was unable to deal fully with nonrandom assignment of workers to firms.
} 
wage inequality. ${ }^{2}$

A priori, workplace heterogeneity could have become more or less important in recent decades. On one hand, increases in product market competition, coupled with institutional reforms, rising labor market intermediation (Autor, 2009) and reductions in the cost of information might be expected to reduce workplace-specific pay components and push labor markets closer to obeying the law of one price. On the other hand, the rise of firm-specific policies like pay-for-performance (Lemieux, MacLeod, and Parent, 2009), outsourcing (Abraham and Taylor, 1996; Dube and Kaplan, 2010), and the use of temporary workers (Segal and Sullivan, 1997), as well as rising complementarities between highly skilled workers (Kremer and Maskin, 1996) might lead to an increase in plant-level variation in wage outcomes. In addition, uneven rates of adoption of the technological innovations that have driven shifts in relative demand for different skill groups (e.g. Autor, Levy, and Murnane, 2002, 2003; Acemoglu et al., 2007; Acemoglu and Autor, 2011), could also lead to a rise in the employer component of wage inequality.

We contribute to the literature by studying the changing role of workplace heterogeneity in wage determination using detailed administrative data from West Germany over the period from 1985 to 2009. Several factors make the West German case particularly informative. First, as documented by Dustmann et al. (2009), West Germany experienced large increases in wage inequality from the mid-1990s onward. ${ }^{3}$ Figure 1a shows the evolution of various real wage percentiles for full time male workers, indexed to a base of $1996 .{ }^{4}$ In the 13 -year period from 1996 to 2009, the gap between the 20th and 80th percentiles of wages expanded by approximately 20 log points. By comparison, as shown in Figure 1b, the burst of wage inequality in the U.S. during the 1980s led to a 15 log point rise in the 80-20 gap in male hourly wages. ${ }^{5}$ Interestingly, the recent rise in German inequality arose through a roughly symmetric widening of the upper and lower tails of the wage distribution, whereas in the U.S. the inequality growth was muted in the lower tail, perhaps reflecting the impact of the minimum wage (Lee, 1999).

\footnotetext{
${ }^{2}$ Barth et al. (2011) find that between plant inequality has grown over time in the U.S. but are unable to fully account for changes in the pattern of sorting of workers to firms due to limitations in their data. Cardoso $(1997,1999)$ provides evidence that between plant wage variation grew in Portugal but is again unable to fully account for selection of workers into firms based upon unobservables. Skans et al. (2009) provide similar between-plant evidence for Sweden.

${ }^{3}$ Dustmann et al. (2009) also present data for earlier periods and show that, as suggested in Figure 1a, there was a general trend to toward rising inequality even prior to the mid-1990s.

${ }^{4}$ The data underlying this figure are described in detail in Section 3, below.

${ }^{5}$ The data in Figure 1b are based on real hourly wage percentiles for men compiled from the outgoing rotation group files of the Current Population Survey by the Economic Policy Institute (EPI, 2009). Other wage series for the U.S., such as wages of full-time full-year male workers, show a somewhat larger rise in U.S. male wage inequality in the 1980s: see Autor, Katz and Kearney (2008).
} 
A second key feature of the West German case is the availability of high quality administrative data derived from the German Social Security system. These data include spell-level information on average daily wages, education, and occupation. Crucial for our purposes, the data have been collected on a consistent basis for a relatively long period, including several years prior to the most recent surge in inequality. ${ }^{6}$

Third, Germany provides an interesting setting for analyzing the evolution of firm-specific heterogeneity and wage-setting more generally. In the past three decades Germany experienced reunification and the aftermath of the fall of communism, undertook multiple labor market reforms, witnessed a sharp decline in collective bargaining coverage, and emerged from a long period of under-performance (e.g., Siebert, 1997) to become one of the most successful economies in the OECD. ${ }^{7}$ There is widespread interest in the source of this recent success, and the lessons it may hold for other countries (e.g., Burda and Hunt, 2011).

To study the changing role of workplace heterogeneity we divide our 25-year sample period into four (overlapping) intervals: a period of relative stability from 1985 to 1991; a transitional period following reunification (1990-1996); a period spanning the wave of reforms initiated in the mid-1990s (1996-2002); and a period covering the most recent decade (2002-2009). In each interval, we fit linear wage models that include additive person and establishment fixed effects as in Abowd, Kramarz and Margolis (AKM, 1999). We then compare the estimates across intervals to assess changes in the structure of wages. By fitting separate models in each relatively short interval we can allow for longer-run changes in the earnings characteristics of individual workers and firms caused by changes in technology, innovations in workplace practices, or other factors.

In an initial methodological contribution we present new diagnostic evidence on the quality of the approximation to the wage structure provided by AKM's additive worker and firm effects model. We find that, in contrast to conventional wage models, the AKM model explains roughly $90 \%$ of the rise in wage inequality over our sample period. We also find that the separability assumptions of the AKM model are nearly (but not perfectly) met in the data. For comparison we fit generalized models that include separate fixed effects for each job (i.e., worker-establishment match) and show that these models provide only a small improvement in explanatory power relative to the AKM specification. Moreover, the difference in residual variance between the match model and the AKM model increases only slightly over time. Thus, a fully unrestricted match model provides almost no additional explanatory power for understanding the rise in wage inequality. We also conduct a series of

\footnotetext{
${ }^{6}$ By contrast, in the U.S., high quality employer-employee data is only available beginning in the 1990s, the geographic coverage is incomplete, and administrative education records are not available.

${ }^{7}$ For overviews of recent changes in the German labor market see Eichhorst and Marx (2009), Burda and Hunt (2011), and Eichhorst (2012).
} 
checks for patterns of endogenous mobility that could lead to systematic bias in the AKM specification and find little evidence of such biases.

Our primary substantive contribution is a simple decomposition of the sources of rising wage inequality in West Germany. We find that the increase is attributable to increases in the variability of both the person-component of pay (capturing differences in ability, training, motivation, etc.) and the establishment-level component of pay, coupled with a rise in the assortativeness of the job-matching process that magnifies their joint effect. ${ }^{8}$ In the earliest years of our sample the correlation between the worker- and establishment-level components is close to zero. By the final years, however, the correlation is roughly 0.25 , and is clearly discernible in simple plots of their joint distribution. Overall, the rise in the variance of the person component of pay constitutes about $40 \%$ of the rise in the variance of wages, the rise in the establishment component constitutes around 25\%, and their rising covariance constitutes about a third.

We go on to use our estimated models to decompose the changes in between-group inequality across different education, occupation, and industry groups. We find that nearly all of the increase in the conventional return to schooling over our sample period is attributable to changes in the association between education and establishment quality. Better-educated workers in West Germany are increasingly concentrated at high-wage establishments, while less-educated workers are increasingly concentrated at low-wage establishments. We find that rising assortativeness between workers and establishments also explains an important share (around 40\%) of the growth in inequality across occupations and industries.

Given the increasing variability in establishment-based pay premiums, we then briefly examine some of the proximate channels for this rising dispersion. Stratifying establishments by their "birth" year, we find a trend toward increasing heterogeneity among establishments entering after the mid-1990s, coupled with relatively small changes in the variability of the premiums paid by continuing establishments. The trend in inequality among newer establishments is linked to collective bargaining status: an increasing share of new establishments are outside the traditional sectoral contracting system, and pay relatively low wages. We also examine the correlation between pay policies and establishment and job survival. We find that establishments with higher wage premiums are more likely to survive than those with lower wage premiums, consistent with a rent-based explanation for these premiums. Job survival rates are also higher at higher-paying establishments, ruling out a simple compensating differentials explanation for the wage premiums.

\footnotetext{
${ }^{8}$ Recent contributions by Andersson et al. (2012) and Bagger, Sorensen, and Vejlin (2012) also document increases in assortative matching between workers and employers. Those studies use related statistical methods but assume that person and establishment effects are stationary over the entire sample period. They also study settings where the rise in cross sectional inequality is relatively modest.
} 
Our results suggest that a rising share of wage inequality is attributable to variation in the job opportunities available to a given worker, and that both observed and unobserved dimensions of worker skill are increasingly associated with establishment-specific pay premiums. These findings raise a number of questions regarding the determinants of the aggregate composition of offered jobs and the process by which workers are matched with employers. We conclude with a brief discussion of the implications of our findings for the wage inequality literature and directions for future research.

\section{Background - Macro Trends and Institutional Changes}

Some of the key events that have affected the West German labor market since the early 1980s are summarized in Figure 2, which also shows the evolution of the unemployment rate. A decisive turning point was the reunification of East and West Germany, which culminated with economic integration in June 1990 and full political integration several months later. Reunification and the end of communism in eastern Europe affected the West German labor market in many ways. One channel was migration: approximately 1.7 million former residents of East Germany (about 10 percent of the population) moved to the west (see Burda, 1993 and Wolff, 2009). An even larger inflow (approximately 2.8 million people) of ethnic Germans arrived from Russia and other former East Bloc countries between 1988 and 2000. ${ }^{9}$ These new migrants - many of whom lacked modern training and language skills - arguably contributed to the rise in unemployment in the 1990s (Glitz, 2012).

More subtly, the decision to impose West German wage scales on the far less productive east led to rising pressures on the sectoral bargaining system. Traditionally, most West German firms accepted the provisions of the major sectoral agreements negotiated between employer associations and large unions. Unlike Italy or Spain, however, German law does not require firms to follow these centralized agreements (see Ochel, 2003 for an informative overview). Instead, employers can leave the employer association (or refrain from joining in the first place) and either negotiate a workplace-specific agreement or opt out of collective bargaining altogether.

As many observers have noted, the fraction of employees covered by sectoral agreements has fallen since the early 1990s (e.g., Dustmann et al., 2009). The dashed line in Figure 2 shows the fraction of West German workers whose wages are set outside the sectoral agreement system, estimated from information collected by the Institute for Employment Research (IAB) from a large panel of establishments (Kohaut and Ellguth, 2008; Ellguth, Gerner, and Stegmaier, 2012). This fraction has risen from $27 \%$ in 1995 (with $10 \%$ of

\footnotetext{
${ }^{9}$ See Bauer and Zimmerman (1999).
} 
workers in enterprise-level agreements and $17 \%$ with no agreement) to $44 \%$ in 2007 (with $7 \%$ of workers in enterprise-level agreements and $37 \%$ with no agreement). ${ }^{10}$

A second and related phenomenon is the adoption of "opt-out" or "opening" clauses by firms that have remained part of the sector-level agreement (e.g., Hassel and Rehder, 2001; Heinbach, 2006). These clauses allow employers - or individual plants of a large firm - to depart from the agreement, typically in response to the threat of plant closure or job loss. ${ }^{11}$ A study by Hassel and Rehder (2001) suggests that about one-half of the top 120 firms in Germany had signed opening clauses by 2000, and that about $43 \%$ of their employees were covered by these pacts. ${ }^{12}$

By the mid-1990s the unemployment rate in Germany had risen to nearly 10 percent, and intensifying pressure for labor market reform led to the passage of the Labor Law Act for Promotion of Employment in October 1996. This law extended the maximum duration of fixed-term contracts from 1 to 2 years, raised the establishment size threshold for dismissal protection from 5 to 10 employees, and reduced the replacement rate for sick leave pay from $100 \%$ to $80 \%$. The trend toward liberalization was partially reversed after the election of 1998. So-called "marginal jobs" (part-time jobs with low earnings) that had previously been excluded from coverage by Social Security taxes were brought into the tax system in $1999 .{ }^{13}$ With the recession in 2001, however, pressures for reform returned, ultimately leading to adoption of the Hartz reforms in 2003-2005. These included major revisions to the benefit program for those who have exhausted regular unemployment benefits (see e.g., Jacobi and Kluve, 2006), including a subsidy for taking low-wage jobs. In addition, the employee share of Social Security taxes for part-time jobs (so-called "mini-jobs") was eliminated, providing further impetus for the expansion of part-time/low wage jobs.

A final institutional change documented in Figure 2 is the adoption of a minimum wage for construction workers in November 1996. The impetus for this law - the first legallyimposed minimum wage in Germany - was the rising presence of immigrant workers who

\footnotetext{
${ }^{10}$ As discussed by Fitzenberger et al. (2012), not all workers in a given establishment necessarily have the same contractual coverage status. For example, managers and temporary workers (who are included in our data set) are exempt. The coverage rate shown in Figure 2 assigns a single establishment status to all employees and should be interpreted carefully.

${ }^{11}$ For example, the 1993 sectoral agreement in metal working provided for an opening clause (or hardship clause) for plants in East Germany. As of the mid-1990s, the East German metalworking employer association estimated that $60 \%$ of plants were making use of the clause (EIRO, 1997a). The 1997 sectoral agreement in the chemical industry in West Germany allowed for plant-specific opening clauses cutting wages by up to $10 \%$ to save jobs (EIRO, 1997b).

${ }^{12}$ Many firms that recognize the sectoral contract also pay a wage premium above the sectoral minimum (see Jung and Schnabel, 2009). We are not aware of any research that shows whether this so-called "wage cushion" component has become more or less variable over time.

${ }^{13}$ The firm size threshold for dismissal protection was also raised back to 10 employees, and fixed term contracts were limited to initial employment only (instead of being renewable).
} 
were eligible to work in Germany but subject only to wage regulations of their home country (see Bachman et al., 2012). The minimum was set at a relatively low level, however, and research by Rattenhuber (2011) and Bachman et al. (2012) suggests it had little effect in West Germany (though a larger impact in the lower-wage East). More recently, minimum wages have been introduced for employees in the cleaning industry and the temporary help industry - see EIRO (2007, 2012).

\section{Data}

We use earnings information from the German Social Security system that has been assembled by the Institute for Employment Research into the Integrated Employment Biographies (IEB) datafile. Employers are required to submit a notice of employment to the Social Security system for all employees in a calendar year, giving the starting and ending date of their job, total earnings received (censored at the maximum taxable earnings level), the establishment identification number, and other data, including the employee's education, occupation, and trainee status, and whether the job was part-time or full time. Multiple records are submitted for workers who change job status - e.g., from part-time to full time - or who have interrupted employment spells during a year. Nearly all private sector employees in Germany are subject to Social Security taxation and are included in the data base. The major excluded groups are civil servants and the self-employed.

We limit our attention to full-time jobs held by men age 20-60 during the period from 1985 to 2009. ${ }^{14}$ We also exclude marginal jobs (or "mini-jobs") that are subject to reduced Social Security contributions ${ }^{15}$ and jobs in which the employee is undergoing training. As explained in more detail in the Data Appendix, we sum the earnings received by a given individual from each establishment in each year and designate the one that paid the highest total amount as the main job for that year. Most full time men work at only one establishment in any year (the average is 1.1 per year) and there is no trend in the number of jobs held per year, so the restriction to one job per year is unlikely to be important in explaining trends in wage inequality. (See Appendix Table 1a). We calculate the average daily wage by dividing total earnings by the duration of the job spell (including weekends and holidays). An individual

\footnotetext{
${ }^{14}$ Our focus on full time jobs is driven by the absence of data on hours of work, although only a small fraction of men (under $6 \%$ in most years of our sample) are employed in part time jobs. We exclude females because a relatively high (and increasing) fraction work part-time. Anotnczyk, Fitzenberger, and Sommerfeld (2010) show that the male-female wage gap in Germany was quite stable between 2001 and 2006, though both groups were affected by declining collective bargaining coverage and other factors. As discussed below, inequality trends for full time female workers are not too different from those of men.

${ }^{15}$ These jobs were not subject to Social Security taxation prior to 1999, so it is impossible to conduct an analysis over our sample period that includes marginal jobs.
} 
who has no full time job in a given calendar year is assigned a missing wage for that year.

The use of administrative data allows us to sidestep the nonresponse problems that increasingly plague survey data (Hirsch and Schumacher, 2004; Kline and Santos, 2012). It is worth noting, however, that our sample restrictions probably lead to an understatement of the overall level of wage inequality among West German male workers, and of the rise in inequality for these workers. ${ }^{16}$ On the other hand, we cannot control for variation in hours of work. Nevertheless, an analysis by Dustmann et al. (2009, Appendix Table 7) of data from the German Socio-economic Panel (GSOEP) shows no change in the variance of hours of full time male workers in West Germany after 1990, so we suspect that rising hours variation is not a major source of the rise in wage inequality we document below.

The establishment identification numbers (EID's) we use to identify workplaces are assigned by the Social Security system on the basis of ownership, industry, and municipality. Two fast food outlets owned by the same company in the same city generally will be classified as a single establishment, whereas a foundry and a fabrication plant owned by the same company in the same municipality will be classified as separate establishments. A new EID is issued when a plant changes ownership, and can also be issued for other reasons. Thus, the "death" of an establishment identifier does not necessarily mean that a plant has closed, nor does the "birth" of a new EID necessarily mean that a new plant has opened. Using clusters of worker flows between establishments, Schmeider and Hethey (2010) estimate that only about one half of EID births and deaths in the IEB are true plant openings or closings.

Since our primary interest is in wage determination, we believe it is appropriate to treat an ownership change as a potential change in the workplace component of pay, even when a plant remains open. Ownership changes may lead to new pay policies (e.g., adoption of incentive pay) or changes in the organization of work (such as outsourcing of low-skilled jobs) that we believe are properly interpreted as changes in the workplace component of pay. In cases where a new EID is assigned without any change in ownership, there is no bias in treating the "new" EID as a new establishment, only a potential loss in efficiency, since the old and new establishments can have the same impacts on wages.

Appendix Table 1b shows some basic characteristics of our data set. We have 12-14 million workers with a wage in any year. Average real annual and daily earnings of the men in our sample rise between 1985 and 1990, but are quite stable over the next 20 years. In contrast, the dispersion in pay - measured by the standard deviation of daily wages - rises dramatically. ${ }^{17}$ At the establishment level, there are about 800,000 EID's in each year with

\footnotetext{
${ }^{16}$ See below for an analysis of trends including part-time jobs. Eichhorst and Marx (2009) analyze data from the German Socio-Economic Panel (GSOEP), and show that the incidence of marginal jobs rises from about $2 \%$ of adults in the early 1990 s to $5 \%$ by 2007 .

${ }^{17}$ Riphahn and Schnitzlein (2011) analyze data from the SIAB, a $2 \%$ sample of the IEB database, and
} 
at least one full time male employee. The size distribution of establishments (measured by the number of full time male employees) is highly skewed, but fairly stable over time, with only a small decline in the share of large (over 350 workers) establishments. The median establishment in any year of the sample has 2 workers, but on average a typical worker has about 1,000 (full time male) co-workers. Appendix Figure 1 shows the size distributions in 1985, 1995, and 2008, illustrating both their extreme skew and their stability over time.

An important limitation of our data set is the censoring of earnings at the annual Social Security earnings maximum. Appendix Figure 2 shows the fraction of censored observations in each year of the sample, which varies from 10 to 14 percent. To address the problem of censoring, we follow Dustmann et al. (2009) and use a series of 500 Tobit models fit separately by year $\times$ education level $(5$ categories $) \times$ age range $(410$-year ranges $)$ to stochastically impute the missing upper tail of the wage distribution. Since our primary wage determination models include person and establishment effects, we impute a censored value in a given year using information on the worker's earnings in other years, and on his co-workers' earnings in the same year. Specifically, the Tobit model for a given year includes the worker's earnings and censoring rate in all other years, as well as the mean earnings and censoring rate of his co-workers in that year. (See the Data Appendix for more detail and Appendix Table 2 for coefficient estimates from several representative models). Using the estimated parameters from these models, we replace each censored wage value with a random draw from the upper tail of the appropriate conditional wage distribution.

The impact of this imputation procedure is illustrated in Appendix Figure 2, which shows the differences in the estimated mean and standard deviation of log daily wages in each year using the imputed values for the censored observations versus using the data with no adjustment for censoring. On average the imputation raises the estimated mean log wage by 2.7 percentage points and the estimated standard deviation by 4.5 percentage points, with larger effects in years with a higher censoring rate.

Although we believe that this imputation procedure works reasonably well, a natural concern is that our analysis would yield different results if we used a different technique. ${ }^{18}$ To address this concern, we present robustness checks based on the subset of workers with apprenticeship training. This group, which includes about 60 percent of the German male workforce, has relatively low censoring rates. Reassuringly, our main conclusions are very similar when we use only the apprentice subsample.

reach a similar conclusion about the near constancy of mean or median real wages of full time workers (male and female) in West Germany from 1993 onward.

${ }^{18}$ Dustmann et al. (2009) present an extensive robustness analysis in which they evaluate several alternatives to their basic Tobit imputation models, and conclude that they give similar results. 


\section{Overview of Trends in Wage Inequality}

Figure 3a plots four measures of wage dispersion over time: the standard deviation of log wages (including imputed wages for censored observations), the gap in log wages between the 20th and 80th percentiles, the gap between the 50th and 80th percentiles, and the gap between the 20th and 50th percentiles. We normalize the gap measures by dividing by the corresponding percentile gaps for a standard normal variate. ${ }^{19}$ If log wages were normally distributed, the three normalized gaps and the standard deviation would all be equal. Inspection of the figure suggests that log daily wages have fatter tails than a normal distribution, but that the trends in the standard deviation and the normalized 80-20 gap are very similar. In particular, the standard deviation rises by 0.15 from 1985 to 2009 whereas the normalized $80-20$ gap rises by 0.16 . This similarity is reassuring because the $80-20$ gap is unaffected by censoring. A second conclusion is that the rise in lower-tail inequality is slightly bigger than the rise in upper-tail inequality: the normalized 80-50 gap rises by 0.15 , whereas the normalized 50-20 gap rises by 0.18. A third conclusion is that the rates of growth in all four measures of inequality increased sometime in the mid-1990s. For example, the standard deviation of log wages grew by 0.0023 per year from 1985 to 1996 and by 0.0096 per year from 1996 to 2009.

While our focus throughout this paper is on full-time male workers, we have also constructed measures of wage inequality based on the 80-20 log wage gap for other samples of West German workers. ${ }^{20}$ Appendix Figure 3 shows the trends in wage inequality over our sample period for full time male workers, all male workers (except those in mini-jobs), full time female workers, and all female workers (except those in mini jobs). Since only a small fraction of male workers hold part time jobs (under $2 \%$ at the start of our sample, and under $7 \%$ at the end) the rise in inequality for all males is very similar to (but slightly larger than) the rise for full time males. Wage inequality among full time female workers is higher than among full time men and rises somewhat less over our sample period, though the general patterns for the two groups are quite similar. The inequality in daily wages among all female workers is even higher, reflecting a large and rising fraction of part time workers ( $23 \%$ of all female workers in 1985, rising to $37 \%$ by 2008), but shows a smaller rise than for men (as is

\footnotetext{
${ }^{19}$ For example, we divide the 80-20 gap by $\Phi^{-1}(0.8)-\Phi^{-1}(0.2)=1.683$, where $\Phi($.$) represents the standard$ normal distribution function.

${ }^{20}$ For this analysis we use the Sample of Integrated Labor Market Biographies (SIAB), a two-percent public use sample that combines information from the IEB with other administrative data bases (Dorner et al., 2011). We use the same procedures as for our IEB sample but do not impute wages for censored observations. Riphahn and Schnitzlein (2011) use the SIAB data to document trends in inequality for men and women together in West and East Germany. Their results for West Germany are very similar to ours. They show that wage inequality in East Germany has risen somewhat faster than in the West.
} 
also true in the U.S. - see Autor, Katz and Kearney, 2008).

Starting with the seminal U.S. studies by Katz and Murphy (1992) and Bound and Johnson (1992), analysts have noted that a large share of the recent rises in wage inequality have occurred within conventional skill groups. This is also true in our data, as shown in Figure 3b, which plots the same four measures used in Figure 3a, but applied to the residuals from a standard human capital earnings function (with dummies for education levels and a cubic experience term) fit separately by year. Residual inequality rises somewhat less than overall wage inequality (e.g., the standard deviation of residual wages increases by 0.13 from 1985 to 2009 , about $4 / 5$ ths of the rise in overall inequality), but exhibits the same acceleration in trend in the mid-1990s. Interestingly, residual inequality is nearly symmetric, suggesting that the increasing skew in overall wage inequality is largely explained by increasing returns to education and experience.

\section{Explaining the Rise in Residual Wage Inequality}

Several recent studies have suggested that part of the rise in U.S. wage inequality is attributable to a rise in the variation in wages across geographic areas (Moretti, 2012) occupations (e.g., Autor, Levy and Murnane, 2003; Autor, Katz and Kearney, 2008) or industries (Autor, Katz, and Krueger, 1998; Bernard and Jensen, 1995). Figure 4 summarizes the contributions of these factors to the rise in West German wage inequality. The top line in the figure shows the trend in the standard deviation of residual wage inequality, adjusting for education and experience as in Figure 3b. The other lines show the trends in residual standard deviation, adding controls (with separate coefficients in each year) for Federal State (10 dummies), industry ( $\sim 300$ dummies), occupation ( $\sim 340$ dummies $)$, and industry $\times$ occupation $(\sim 28,000$ dummies). While industry and occupation controls clearly add to the explanatory power of a standard wage equation, they have only a modest impact on the trend in residual inequality. ${ }^{21}$ We return in Section 6, below, to examine in further detail the trends in between-occupation and between-industry inequality in light of our econometric decomposition of wage inequality into person and establishment effects.

In contrast to the limited effect of industry and occupation controls, the bottom line in Figure 4 shows that adding dummies for each establishment (with year-specific coefficients) has a sizeable impact on the trend in inequality. Within-plant inequality, as measured by the root mean squared error (RMSE) of the regression model rises by only 0.05 between 1985 and 2009, compared to the 0.13 rise in the RMSE of the baseline model that controls for

\footnotetext{
${ }^{21} \mathrm{~A}$ basic human capital model (dummies for education and cubic in experience) has an $R^{2}$ coefficient of about 0.35 . Adding industry or occupation controls raises the $R^{2}$ to about 0.50 . Adding the interaction of occupation and industry raises it to about 0.60 .
} 
education and experience.

Although this contrast suggests that workplace heterogeneity may play some role in explaining the rise in German wage inequality, we emphasize that these wage models do not control for unobserved worker abilities. The rise in the explanatory power of the workplace effects may simply capture the non-random sorting of workers to establishments. Specifically, even if all workers receive the same wage regardless of where they work, one could still observe significant and increasingly important workplace effects if workers at the same establishment have similar unobserved abilities, and if the returns to these abilities are rising over time, or if the degree of sorting across establishments is rising over time.

\section{Measures of Labor Market Sorting}

Figure 5 shows that two measures of workplace sorting are indeed rising over time in West Germany. The first is an index of the degree of sorting of workers of different education levels to individual workplaces. Following Abowd, Kramarz, and Margolis (1999) we index the assignment of workers to establishments via the function $\boldsymbol{J}(i, t)$ which yields the identity of the establishment associated with worker $i$ in year $t$. Our sorting measure consists of the coefficients $b_{t}$ from a series of regressions of the mean level of schooling at worker $i^{\prime} s$ establishment in year $t\left(\bar{S}_{\mathbf{J}(i, t) t}\right)$ on his own schooling $\left(S_{i}\right)$ :

$$
\bar{S}_{\mathbf{J}(i, t) t}=a_{t}+b_{t} S_{i}+e_{i t}
$$

As noted by Kremer and Maskin (1996), $b_{t}$, can range from 0 (no sorting) to 1 (perfect sorting). ${ }^{22}$ Over our sample period the value of $b_{t}$ has increased by about 40 percent, from 0.34 to 0.47 .

Our second measure of sorting examines the degree of occupational segregation across workplaces. Specifically, we divide occupations into 10 (approximately) equally sized groups, based on mean wages of full time male workers in the occupation in 1985-1991. ${ }^{23}$ We then compute Theil indices of segregation for the decile groups across establishments (Theil and Finezza, 1971). ${ }^{24}$ The Theil index ranges from 0 (perfect integration) to 1 (perfect segrega-

\footnotetext{
${ }^{22}$ It is straightforward to show that $b_{t}$ measures the fraction of the variation in schooling attainment that occurs between establishments. We construct a linear measure of schooling by assigning 10.5 years to individuals with missing education, 11 years to those with lower secondary schooling and no vocational training, 13 years to those with lower secondary schooling and vocational training (i.e., conventional apprenticeship completers), 15 years to those with an abitur (advanced high school degree) with or without further vocational training, and 18 years to those with university degree. We also include in these regressions controls for a quadratic in potential experience.

${ }^{23}$ For example, occupation group 1 contains all three-digit occupations with mean wages in the bottom decile of occupational wages.

${ }^{24}$ The Theil index may be written:
} 
tion) and can be interpreted as a rescaled likelihood ratio test for the null hypothesis that every establishment employs the national occupation mix. Over our sample period the index rises by roughly 15 percent from 0.46 to 0.53 . Together, the results in Figure 5 suggest that increased sorting could account for at least part of the rise in the importance of establishment effects in a wage model.

\section{An Event Study Analysis}

To investigate whether sorting is likely to explain the bulk of the workplace component of wages, Figures 6a and 6b provide simple event-study analyses of the wage effects of job transitions in the first (1985-1991) and last (2002-2009) intervals in our sample. In both cases, we examine wages in the two years before and two years after a job change for workers moving between establishments with different mean pay levels. If between-plant wage variation is primarily driven by variation in unobserved worker quality, transitions between high and low wage plants should not be associated with major wage changes for a given worker.

To avoid selecting on the job-changer's own wage we classify jobs based on the mean wages of co-workers, omitting the wage of the individual being studied (i.e., using the "leave-out mean" wage). ${ }^{25}$ Specifically, we begin by calculating the distribution of mean co-worker wages across all person-year observations in a given time interval. For each job changer, we then classify the old job based on the quartile of its mean co-worker wage in the last year at the job. We similarly classify the new job based on the quartile of its mean co-worker wage in the first year on the job. We divide job changes into 16 cells based upon the co-worker wage quartile of the origin and destination job. For each transition category we then calculate mean worker wages in the years before and after the job change. ${ }^{26}$ For simplicity, the figures present wage profiles for people leaving quartile 1 jobs (with the lowest co-worker wages) and quartile 4 jobs (with the highest co-worker wages). Appendix Table 3 provides a complete listing of mean wages before and after the job change for each of the 16 cells.

Notice first that there is clear evidence of permanent heterogeneity between different

$$
H=1-\frac{\sum_{j} \frac{N_{j}}{N} \sum_{m} \pi_{j m} \log \left(\pi_{j m}\right)}{\sum_{m} \pi_{m} \log \left(\pi_{m}\right)}
$$

where $\pi_{m}$ is the employment share of occupation group $m, \pi_{j m}$ is the employment share of occupation group $m$ at firm $j$, and $\frac{N_{j}}{N}$ is the employment share of firm $j$.

${ }^{25}$ In this exercise, we drop any observations at establishments with a single employee. Note that a job changer could move directly from job to job, or have an intervening spell of non-employment (or part time employment). We exclude job changes that span a full year with no full time job.

${ }^{26}$ Note that we require each lost job to have been held for at least 2 years, and each new job to be held for at least 2 years. Since the sample period includes 8 years, some people can appear in the event study more than once. 
mover groups: for example, the average wages of workers in quartile 4 jobs who move to quartile 1 jobs are lower than those who move to quartile 2 jobs, with similar patterns for the other mobility groups. However, the data also provide clear evidence that transitioning between low and high wage establishments has important effects on compensation. While workers moving between quartile 1 jobs have relatively low but constant wages, quartile 1 workers who move to jobs with higher paid coworkers experience wage increases, with the largest increases for those who move to quartile 4 jobs. Likewise, movers from quartile 4 jobs experience little change (other than a modest upward trend affecting all groups in 1985-1991) if they move to another quartile 4 job, but otherwise suffer wage losses with the largest losses among those moving to quartile 1 jobs.

Comparing Figures $6 \mathrm{a}$ and $6 \mathrm{~b}$, it is clear that the size of the wage gains and losses associated with job transitions grew dramatically over the period of our study. This impression is confirmed by the estimates in Appendix Table 3. In the 1985-1991 interval, a transition from the bottom to the top quartile was associated with a trend-adjusted wage increase of roughly 23 log points, while in the 2002-2009 interval, the same transition was associated with a 36 log point increase. Likewise, in the 1985-1991 interval, a transition from the top to the bottom quartile was associated with a trend-adjusted wage drop of 22 log points, while in the 2002-2009 interval, the same transition yielded a 48 log point drop. This striking growth in the magnitude of the wage changes associated with job changes is a key finding, and underlies our results in Section 6 on the growing role of establishment heterogeneity in wage inequality.

Another remarkable feature of Figures $6 \mathrm{a}$ and $6 \mathrm{~b}$ is the approximate symmetry of the wage losses and gains for those who move between quartile 1 and quartile 4 establishments. This symmetry suggests that a simple model with additive worker and establishment effects may provide a reasonable characterization of the mean wages resulting from different pairings of workers to establishments. ${ }^{27}$ Though not shown in the Figures, the gains and losses for other mover categories exhibit a similar degree of symmetry (see Appendix Table 3), particularly after adjusting for trend growth in wages. Note as well that moving from a bottom quartile to a top quartile firm results in mean wages roughly equal to those of a worker at a top quartile firm prior to transitioning to a bottom quartile firm. Thus, among workers in a particular mobility class (e.g., those who worked at both a top and bottom quartile firm), the establishment effect for the current job explains most of the wage differences between

\footnotetext{
${ }^{27}$ Notice that if the mean $\log$ wage paid to worker $i$ at establishment $j$ can be written as $m_{i j}=\alpha_{i}+\psi_{j}+z_{i j}$, where $z_{i j}$ is a random error, then the average wage gain for moving from establishment $j$ to establishment $k$ is $\psi_{k}-\psi_{j}$, while the average gain for moving from $k$ to $j$ is $\psi_{j}-\psi_{k}$, i.e., the wage changes for movers in the two directions are equal and opposite. If wages contain a common trend component, the trend-adjusted wage changes will be symmetric.
} 
top and bottom quartile workers.

A final important feature of the wage profiles in Figures $6 \mathrm{a}$ and $6 \mathrm{~b}$ is the lack of an Ashenfelter (1978) style dip in the average daily wages of workers who move from higher quartile jobs to lower quartile jobs. ${ }^{28}$ Nor is there any indication of a positive transitory "blip" in the year before a move from a lower quartile job to a higher quartile job. Taken together with the approximate symmetry of the wage transitions noted above, these findings provide suggestive evidence that the wages of movers may be well approximated by the combination of a worker component, an establishment component, and a time varying residual component that is uncorrelated with mobility.

\section{Methods}

With this background, we turn to a discussion of our econometric methods for disentangling the workplace component of wages from the component associated with worker abilities. We begin with some notation. In a given time interval, our data set consists of $N^{*}$ person-year observations on $N$ workers and $J$ establishments. Within each time interval, we model the $\log$ daily wage $y_{i t}$ of individual $i$ in year $t$ as the sum of a time-invariant worker component $\alpha_{i}$, a time-invariant establishment component $\psi_{\boldsymbol{J}(i, t)}$, a linear index of time-varying observable characteristics $x_{i t}^{\prime} \beta$, a mean-zero random match component $\eta_{i \boldsymbol{J}(i, t)}$, a unit root component of individual wages $\zeta_{i t}$, and a mean-zero transitory error $\varepsilon_{i t}$ :

$$
\begin{aligned}
y_{i t} & =\underbrace{\alpha_{i}+\psi_{\boldsymbol{J}(i, t)}+x_{i t}^{\prime} \beta}_{\text {fixed effects }}+\underbrace{\eta_{i \boldsymbol{J}(i, t)}+\zeta_{i t}+\varepsilon_{i t}}_{\text {random effects }} \\
& =\alpha_{i}+\psi_{\boldsymbol{J}(i, t)}+x_{i t}^{\prime} \beta+r_{i t}
\end{aligned}
$$

The person effect $\alpha_{i}$ captures the portion of an individual's earnings power that is fully portable across employers. Much of the variation in $\alpha_{i}$ presumably derives from worker productivity, but it may also reflect heterogeneity in bargaining ability, labor market discrimination, or other factors. The establishment effect $\psi_{j}$ captures a proportional pay premium (or discount) that is common to all employees at workplace $j$. This premium may reflect

\footnotetext{
${ }^{28}$ Ashenfelter (1978) noted that participants in job training programs were likely to have experienced a transitory dip in earnings in the year prior to entering the program. Our setting is somewhat different from Ashenfelter's not only because we are studying job transitions, but because we measure average daily wages, rather than annual earnings, so changes in the number of days worked at a constant wage will not affect our estimates. And if job transitions are preceded by wage changes, we ought to have substantial power to detect them because our average daily wage measure in the year prior to the transition contains only the days over which the individual worked at the preceding job - which may be substantially less than the entire year.
} 
rent sharing, compensating differentials, or other differences across establishments in their compensation policies. The vector of time-varying characteristics $x_{i t}$ captures changes in the portable component of an individual's earnings power. We include in $x_{i t}$ an unrestricted set of year dummies and quadratic and cubic terms in age, all fully interacted with educational attainment. ${ }^{29}$ Thus, $x_{i t}^{\prime} \beta$ captures both lifecycle effects and changes over time in the relative pay of different age/education groups. Because our estimation samples consist of relatively short intervals, the importance of these time varying factors is likely to be smaller than in studies focusing on career development (e.g., Keane and Wolpin, 1997; Topel and Ward, 1992).

The match effect $\eta_{i j}$ allows for a time-invariant wage premium (or discount) for individual $i$ at establishment $j$, relative to the baseline level $\alpha_{i}+\psi_{j}$. We assume that $\eta_{i j}$ has mean zero for every person in every interval and for every establishment in every interval. One source of match heterogeneity in wages is complementarity between the skills of the worker and the needs of the firm. To the extent that the worker has significant bargaining power, this complementarity will be rewarded in the form of higher wages. Other factors that affect an individual's average pay while working for a given employer, such as initial placement in the pay grid or other random factors, will also be included in $\eta_{i j}$.

The unit root component $\zeta_{i t}$ captures drift in the portable component of the individual's earnings power. Innovations to this component could reflect employer learning, human capital accumulation, health shocks, or the arrival of outside offers which, in some models (e.g., Postel-Vinay and Robin, 2002), may bid up the offered wage at the current job and other potential jobs. By definition, $\zeta_{i t}$ has mean zero for each person in each interval but contains a unit root. The potential presence of such a component motivates in part our decision to estimate worker-firm models over relatively short time intervals, during which the variance of $\zeta_{i t}$ is limited. Finally, the transitory component $\varepsilon_{i t}$ represents any left-out mean reverting factors.

It will prove useful to consider the corresponding matrix formulation of this model as it clarifies our discussion of identification and estimation. Let $y$ denote the stacked $N^{*} \times 1$ vector of wages sorted by person and year, $D$ an $N^{*} \times N$ design matrix of worker indicators, $F$ an $N^{*} \times J$ design matrix of firm indicators, $X$ an $N^{*} \times K$ matrix of time varying covariates, and $r \equiv \eta+\zeta+\varepsilon$, an $N^{*} \times 1$ vector of composite errors. Our model in (1) can be written as:

$$
\begin{aligned}
y & =D \alpha+F \psi+X \beta+r \\
& =Z^{\prime} \xi+r
\end{aligned}
$$

\footnotetext{
${ }^{29} \mathrm{We}$ omit the linear term in age as it is not separately identified from the year effects.
} 
where $Z \equiv[D, F, X]$ and $\xi \equiv\left[\alpha^{\prime}, \psi^{\prime}, \beta^{\prime}\right]^{\prime}$.

We estimate (2) by ordinary least squares (OLS). These estimates solve the normal equations:

$$
Z^{\prime} Z \xi=Z^{\prime} y
$$

A unique solution to these equations requires that the matrix $Z^{\prime} Z$ have full rank. This in turn requires a linear restriction on the establishment effects within each "connected set" of establishments - that is, the set of establishments connected directly or indirectly via worker mobility. ${ }^{30}$ To simplify estimation, we restrict our analysis to the largest connected set of establishments in each time interval of interest, which turns out to include more than $97 \%$ of workers and $90 \%$ of establishments (see below). Within this connected set we omit the last establishment dummy, so that the establishment effects are measured relative to establishment $J$. The computational Appendix provides details of our procedure for obtaining a solution to the normal equations. In brief, we use an iterative conjugate gradient algorithm (as in Abowd, Creecy, and Kramarz, 2002) which solves for the vector of coefficients $\xi$ without actually inverting the matrix $Z^{\prime} Z$.

\section{Threats to validity}

For least squares estimates to identify the underlying parameters of interest, we need the following orthogonality conditions to hold:

$$
E\left[D^{\prime} r\right]=0, E\left[F^{\prime} r\right]=0, E\left[X^{\prime} r\right]=0
$$

The assumption of orthogonality between the composite error $r$ and the time-varying covariates $X$ is standard. Moreover, under our assumptions on the means of $\eta_{i j}$, $\zeta_{i t}$, and $\varepsilon_{i t}, E\left[D^{\prime} r\right]=0$. Thus the key concern for identification is whether the composite error is orthogonal to the matrix of establishment identifiers $F$. A sufficient condition is that job mobility patterns are independent of $(\eta, \zeta, \varepsilon)$ - a so-called "exogenous mobility" assumption. In this section we discuss the deviations from full independence suggested by different models of wage determination and mobility, and the likely impact of these deviations for OLS estimates of (1).

We consider three sources of mobility to be of particular interest, each corresponding to one of the components of $r$. First, establishments may be subject to transitory demand shocks that induce a group-level component in wages (i.e., $\varepsilon_{i t}$ in (1) contains an establishment $\times$ year component). If workers tend to transition between tightly connected networks

\footnotetext{
${ }^{30}$ See Abowd, Kramarz, and Margolis (1999) and Abowd, Creecy, and Kramarz (2002) for discussion.
} 
of establishments, then a bad year for a particular establishment may predict flows to a particular set of destinations. If this is so, establishment effects at those destinations will be overstated relative to the establishment that experienced the negative shock. ${ }^{31}$ Note that under such a sorting mechanism, we should expect mobility to be preceded by a drop in wages. As noted in the discussion of Figures $6 \mathrm{a} / 6 \mathrm{~b}$, however, such patterns do not seem to be present in the data. We present additional evidence to this effect later in the paper.

A second source of bias could arise if workers systematically sort to firms based on the permanent match component of wages, $\eta_{i j}$. If workers tend to gravitate to jobs where their idiosyncratic match is better, the average wage of the workers actually observed at establishment $j$ will include a sorting bias component of the form that arises in a standard Roy (1951) model. ${ }^{32}$ Substantial sorting based on the match effects changes the interpretation of the estimated establishment effects, since the impact of transitioning between establishments depends on the comparative advantage of the individuals making the transition.

It is possible to test for such sorting in two ways. First, if workers tend to select jobs based on the match component, then we should expect to see that the (trend adjusted) wage gains for workers who move from one establishment to another are quite different from the wage losses for those who move in the opposite direction. Ignoring any wage growth arising from experience or year effects, and the unit root and transitory components in the residual $r_{i t}$, the expected wage change for workers who move from establishment 1 to establishment 2 between period $t-1$ and $t$ is:

$$
E\left[y_{i t}-y_{i t-1} \mid i \text { moves from } 1 \text { to } 2\right]=\psi_{2}-\psi_{1}+E\left[\eta_{i 2}-\eta_{i 1} \mid i \text { moves from } 1 \text { to } 2\right],
$$

while the expected wage change for workers who move in the opposite direction is

$$
E\left[y_{i t}-y_{i t-1} \mid i \text { moves from } 2 \text { to } 1\right]=\psi_{1}-\psi_{2}+E\left[\eta_{i 1}-\eta_{i 2} \mid i \text { moves from } 2 \text { to } 1\right] .
$$

By contrast, under our maintained assumptions, the expected wage changes are $\psi_{2}-\psi_{1}$ and $\psi_{1}-\psi_{2}$, respectively. As the importance of the match components increase, the sorting bias terms $E\left[\eta_{i 2}-\eta_{i 1} \mid i\right.$ moves from 1 to 2$]$ and $E\left[\eta_{i 1}-\eta_{i 2} \mid i\right.$ moves from 2 to 1$]$, both of which are positive, will dominate, leading to wage gains in both directions. We have already seen from the simple event studies in Figures $6 \mathrm{a}$ and $6 \mathrm{~b}$ (and the mean wage changes in Appendix Table 3) that the gains associated with transitioning from a low- to a high- co-workerwage establishment are roughly equal to the losses associated with moving in the opposite

\footnotetext{
${ }^{31}$ Over a long enough horizon these good and bad shocks to firms ought to average out to zero and the importance of such biases will diminish.

${ }^{32}$ See French and Taber (2011) for a detailed discussion of Roy-type models and references to the related literature.
} 
direction. Moreover, workers who move between establishments with similar co-worker wages experience little or no average wage gain. We examine these issues in more detail below by looking directly at wage changes for workers who move between establishments with different estimated fixed effects, and reach the same conclusions: wage gains and losses are (roughly) symmetric for movers between higher- and lower-wage establishments. Moreover, there is no mobility premium for moving between establishments with similar estimated fixed effects.

Second, if match effects are important, a fully saturated match-effects model that includes a separate dummy for each job ought to fit the data much better than our additively separable baseline model. Specifically, the root mean squared error (RMSE) from the AKM specification should be much larger than the RMSE from a model with unrestricted job effects. As we show below, a job match model has a better fit statistically, but the reduction in RMSE is small (11-15\%), implying that the magnitude of the match component is small (the implied standard deviation of $\eta_{i j}$ is in the range 0.06-0.08). ${ }^{33}$ Likewise, any specification errors in the additively separable model in (1) - would be expected to become larger over time if workers and establishments are becoming increasingly heterogeneous. In fact, we find the gap in fit between the AKM model and an unrestricted match effects model is relatively stable over time, which is consistent with our characterization of the match component as an uncorrelated random effect.

A third form of endogenous mobility could arise if drift in the expected wage a person can earn at all jobs (i.e., the shocks to the unit root error component $\zeta_{i t}$ ) predicts firm-to-firm transitions. For example, in learning models with comparative advantage (e.g., Gibbons et al., 2005) some components of worker ability are revealed slowly over time, and these components are valued differently at different establishments. ${ }^{34}$ Under such a scenario, workers who turn out to be more productive than expected will experience rising wages at their initial employer, and will also be more likely to move higher-wage establishments (i.e., firms specializing in skilled workers). Likewise workers who turn out to be less productive than expected will experience wage declines, and will be more likely to move to lowerwage establishments. Such patterns will lead to an overstatement of the importance of establishments in an AKM-style model, as the drift component $\zeta_{i t}$ in wages is positively correlated with the change in the establishment effects. As noted in the discussion of Figures $6 \mathrm{a}$ and $6 \mathrm{~b}$, however, we do not see systematic wage trends in the years prior to a move for

\footnotetext{
${ }^{33}$ Note that small match effects in wages do not necessarily imply small match effects in productivity as workers may simply have low bargaining power in negotiating with their employers. Several recent studies have found a low bargaining share for workers (Card, Devicienti, and Maida, 2010; Cahuc, Postel-Vinay and Robin, 2006; Carlsson, Messina, and Skans, 2011).

${ }^{34}$ Gibbons et al. (2005) consider the case where different sectors value skills differently. Their model could be extended to deal with differences across employers within a sector.
} 
workers who move to better or worse jobs, casting doubt on the importance of learning as a major source of bias in our estimates. ${ }^{35}$

The drift component $\zeta_{i t}$ could also be correlated with mobility patterns if workers obtain outside offers which bid up their wages and also predict transitions to higher-wage establishments (as in Postel-Vinay and Robin, 2002). This "offer-shopping" mechanism implies that OLS estimates of an AKM-style model may overstate the importance of establishment effects. Importantly, however, offer shopping cannot explain the patterns of wage losses experienced by workers who move to lower-wage establishments. ${ }^{36}$ Nor can it explain the symmetry in the wage gains and losses associated with transitions between high and low paying establishments exhibited in Figures 6a and 6b.

\section{Results}

We begin our presentation of results with an overview of the samples in each of our four time intervals. Columns 1-4 of Table 1 show the number of person-year observations, the number of individuals, and the mean and standard deviation of log wages within each interval. In each interval we have about 85-90 million person-year observations on wages for about 17 million individual workers. As expected from the patterns in Figure 3a, the standard deviation of wages rises substantially from 0.38 in interval 1 (1985-1991) to 0.51 in interval 4 (2002-2009). Mean log wages rise about 5 percent from interval 1 to interval 2 and then are quite stable.

Columns 5-8 present a parallel set of statistics for the largest connected set of workers in each interval. Mobility rates between establishments are sufficiently high in West Germany that $97 \%$ of person-year observations in each interval, and about $95 \%$ of all workers, are included in the connected set. Mean wages for observations in the connected set are slightly higher than in the overall population of full-time male workers, while the dispersion of wages is slightly lower. Neither the relative size of the connected group, nor the relative mean/standard deviation of wages in that group change across the four intervals, suggesting that there is little or no loss in focusing attention on the largest connected group for the remainder of the paper.

Table 2 summarizes the estimation results for each of the four intervals in our analysis. As shown in the top two rows of the Table, we estimate roughly 16-17 million person and 1.2-

\footnotetext{
${ }^{35}$ Note that "lumpy" learning - in which workers are suddenly revealed to be more or less productive and make a job transition - could generate spurious establishment effects without detectable blips or dips in wages prior to a job transition (Gibbons and Katz, 1992). While bias from such a process would be difficult to detect, existing estimates of the pace of employer learning suggest it usually occurs over a horizon of several years (Lange, 2007).

${ }^{36}$ Wage losses are possible in such models but should not easily be predicted by the average coworker wage at the origin and destination establishment.
} 
1.5 million establishment effects in each interval. To summarize our findings, we report the standard deviations of the estimated person and establishment effects, the standard deviation of the time-varying covariate index $\left(x_{i t}^{\prime} \widehat{\beta}\right)$, and the correlations between these components. ${ }^{37}$ We also report the root mean squared error (RMSE) from the model and the adjusted $R^{2}$ statistic, both of which adjust for the relatively large number of parameters being estimated in our models.

The estimation results in Table 2 point to several interesting conclusions. First, the person effects and the establishment effects both become more variable over time. Second, the correlation between the person and establishment effects rises substantially, from 0.03 in period 1 to 0.25 in period 4 . Relative to these two main components, the covariate index $x_{i t}^{\prime} \widehat{\beta}$ exhibits less dispersion, especially in the three later intervals, when aggregate wage growth was negligible. A third observation is that the residual component of wages is relatively small in magnitude and becomes only slightly more disperse over time. Of the $13 \log$ point rise in the standard deviation of wages across the intervals, only 1.5 log points remain unexplained. The relatively high explanatory power of the AKM model is reflected in the adjusted R-squared statistics, which increase from $90 \%$ to $93 \%$ across the intervals.

The explanatory power of the model is depicted graphically in Figure 7, which shows a relatively stable RMSE for the AKM model over the four intervals. For comparison purposes we also graph the RMSE from a model with unrestricted match effects - that is, a model where each person-establishment combination receives a separate dummy variable. As shown in the last two rows of Table 2, this model fits somewhat better than the baseline AKM model, confirming the presence of statistically significant match effects. Importantly, however, the match effects model explains little more of the rise in inequality than our baseline model, suggesting that the rise in the residual variance in both models is due to a small increase in the transitory component of earnings.

\footnotetext{
${ }^{37}$ These moments are estimated across the person-year observations in the data set. For example, the standard deviation of the estimated person effects is calculated as:

$$
S_{\widehat{\alpha}} \equiv \sqrt{\frac{1}{N^{*}-1} \sum_{i} \sum_{t} d_{i t}\left(\widehat{\alpha}_{i}-\overline{\widehat{\alpha}}\right)^{2}}
$$

where $d_{i t}$ is an indicator for individual $i$ having a valid wage observation in year $t$ and $\overline{\widehat{\alpha}} \equiv \frac{1}{N^{*}-1} \sum_{i} \sum_{t} d_{i t} \widehat{\alpha}_{i}$. Thus, our variability measure is weighted by the number of years each worker has a valid wage in the interval (which averages about 5 years, but can range from 1 to 8 ). Likewise the standard deviation of the estimated establishment effects is:

$$
S_{\widehat{\psi}} \equiv \sqrt{\frac{1}{N^{*}-1} \sum_{i} \sum_{t} d_{i t}\left(\widehat{\psi}_{J(i, t)}-\overline{\widehat{\psi}}\right)^{2}}
$$

where $\widehat{\widehat{\psi}} \equiv \frac{1}{N^{*}-1} \sum_{i} \sum_{t} d_{i t} \widehat{\psi}_{J(i, t)}$, which weights each establishment by the number of person-years of wage data observed at that establishment.
} 
The gap in RMSEs between the baseline model and the match effects model also rises only slightly over time. Based on this gap, the implied standard deviation of the match effects rises from 0.060 to 0.075 . This relative small change is consistent with the hypothesis that the match effects are truly (uncorrelated) random effects as in (1). If instead they were specification errors generated by incorrectly imposing additivity of the person and establishment effects we would expect the fit of the match effects model to improve relative to the baseline model over time as the variance of the person and establishment effects increased.

Additional insight into the nature of the match-specific error components comes from examining the errors for different groups of workers at different establishments. If the match effects are truly random errors in the wage determination process, their mean should be zero for all different types of matches. The first order conditions for the OLS estimator ensure that the residuals for each worker and for each establishment have mean zero. However, there is no such mechanical restriction on interactions between different groups of workers and establishments, providing the basis for a test of the additivity assumptions in the AKM model.

To search for neglected interactions between worker and establishment characteristics, we divide the estimated person and establishment effects in each interval into deciles, and compute the mean residual in each of the 100 crossed person $\times$ establishment decile cells. Figures $8 \mathrm{a}$ and $8 \mathrm{~b}$ show the mean residuals in each cell using data from intervals 1 and 4 . In all cases the mean residuals are very small, and uniformly less than $1 \%$ in magnitude. ${ }^{38}$ The largest deviations appear among the lowest-decile workers and the lowest-decile establishments: for these groups there appear to be small but systematic departures from the additive separability assumptions of the AKM model. A complete investigation of these nonseparabilities is clearly a topic for future research, but given the small magnitude of the deviations we suspect that they have relatively little effect on our basic conclusions.

A second and related diagnostic focuses on the ability of our model to capture the wage dynamics associated with job changes. If mobility is associated with important selection on transitory wage components we ought to see a dip in wages prior to firm transitions. Figure 9a presents an event-study analysis for job transitions in the 2002-2009 period that is similar to the one in Figure 6, but classifies jobs based on the quartile of the estimated establishment effects for the origin and destination workplaces. As in Figure 6, there is little evidence of transitorily low (or high) wages in the year just before a job change. Moreover, the magnitude of the average wage gain for those who move from a quartile 1 to a quartile 4

\footnotetext{
${ }^{38}$ We emphasize that there is no mechanical reason for the mean residuals in each cell to be close to zero. Although there are 20 linear restrictions on the 100 cell means, there are 80 remaining degrees of freedom.
} 
establishment is very similar to the magnitude of the average wage loss for those who move in the opposite direction.

The wage changes shown in Figure 9a for workers who move between quartile 4 and quartile 1 establishments are large (40-45\%). This reflects the rather large (0.23) estimated standard deviation of establishment effects in interval 4 of our sample. Moving from an establishment that is one standard deviation above average in pay to one that is one standard deviation below average generates an approximately 46 percentage point change in wages.

Figure $9 \mathrm{~b}$ plots the mean wage residuals from the AKM model for the same transitions shown in Figure 9a (note the much narrower range of the y-axis). Examination of this figure shows that our model predicts the mean wage changes associated with quartile to quartile firm transitions relatively well, with prediction errors of less than $3 \%$. We take this as evidence that, at a minimum, our approach provides a good first approximation to the wage determination process, consistent with the relatively high adjusted R-squared statistics for the model. We have also looked at the average changes in the AKM residuals for workers who change jobs and find that, in all our sample intervals, these average changes are very close to 0 . Thus, once we control for the establishment fixed effects at the origin and destination, there is no general mobility premium (or penalty) for job changers.

\section{Decomposing changes in the structure of wages}

We now turn to the implications of the estimated models in Table 2 for understanding the rise in wage inequality over time. As noted, the estimated person and establishment effects both exhibit increasing variability over time. Perhaps even more striking is the rise in the correlation between the these effects. ${ }^{39}$ This increase suggests a fundamental change in the way workers are sorted to workplaces. ${ }^{40}$ Figures $10 \mathrm{a}$ and $10 \mathrm{~b}$ provide a graphical illustration of this phenomenon by plotting the joint distributions of the person and establishment effects in intervals 1 and 4. (As in Figures 8a and 8b we divide the two sets of effects into deciles). In interval 1 there is only limited evidence of sorting, with the largest departure from randomness for workers in the bottom decile of person effects, who are disproportionately likely to work at decile 1 establishments. By interval 4, however, the degree of assortative matching

\footnotetext{
${ }^{39} \mathrm{As}$ described in the Appendix, the estimated variance of the person and establishment components will tend to be inflated by sampling error while the covariance between them will tend to be understated. However, we suspect based upon the stable residual variation of our model that the trends in our estimates are unlikely to be driven by this bias. In the next section we consider between-group measures of covariance which avoid problems due to sampling error.

${ }^{40}$ It is important to remember that these components only provide a description of the covariance structure of wages. As pointed out by Lopes de Melo (2008), Lentz and Mortensen (2010), and Eeckhout and Kircher (2011), the correlation between worker and establishment wage effects need not correspond to the correlation between worker and establishment productivity.
} 
has increased dramatically, as evidenced by the relatively high concentrations of high-wage workers at high-wage establishments, and of low-wage workers at low-wage establishments.

To quantify the separate contributions of rising dispersion in person and establishment effects, and increases in assortative matching, we conduct a simple variance decomposition of the form:

$$
\begin{aligned}
\operatorname{Var}\left(y_{i t}\right)= & \operatorname{Var}\left(\alpha_{i}\right)+\operatorname{Var}\left(\psi_{\boldsymbol{J}(i, t)}\right)+\operatorname{Var}\left(x_{i t}^{\prime} \beta\right) \\
& +2 \operatorname{Cov}\left(\alpha_{i}, \psi_{\boldsymbol{J}(i, t)}\right)+2 \operatorname{Cov}\left(\psi_{\boldsymbol{J}(i, t)}, x_{i t}^{\prime} \beta\right)+2 \operatorname{Cov}\left(\alpha_{i}, x_{i t}^{\prime} \beta\right)+\operatorname{Var}\left(r_{i t}\right)
\end{aligned}
$$

in each interval. Table 3 summarizes the results of this decomposition. Between intervals 1 and 4 , the variance of the person effects rose from 0.084 to 0.127 , representing about $40 \%$ of the overall increase in the variance of wages, while the variance of the establishment effects rose from 0.025 to 0.053 , contributing another $25 \%$. The covariance term also rose from 0.003 to 0.041 , adding about $34 \%$ of the total rise in wage variance. Thus all three components contributed to the rise in inequality. The trends in the various components are illustrated in Figure 11, which gives a visual impression of the relative shares of each term.

Table 3 also reports three simple counterfactual scenarios that help to illustrate the relative importance of the various terms. Under the first counterfactual we hold constant the correlation of worker and firm effects (i.e., no change in sorting) but allow the variances of the person and establishment effects to rise. Under this scenario, the variance of wages would have risen by 0.077 , or about $70 \%$ of the actual rise, suggesting that the increase in sorting can account for about $30 \%$ of the rise in variance. In the second counterfactual we hold constant the variance of establishment effects but allow the variance of the person effects and the correlation between the person and establishment effects to rise. Under this scenario the variance of wages rises by 0.072 , suggesting that the rise in dispersion of establishment effects accounts for about a third of the rise in the variance of wages. Finally, in the third scenario we hold constant sorting and the rise in the variance of the establishment effects, leading to a counterfactual rise in the variance of wages of 0.047 (about $40 \%$ of the total actual increase) attributable to the rise in the variability of the person effects.

\section{Robustness Check: Men with Apprenticeship Training Only}

As discussed earlier, one concern with the German Social Security data is censoring, which affects 10-14 percent of men in any year of our sample. Censoring is particularly prevalent among older, university-educated men, up to $60 \%$ of whom have earnings above the maximum rate. To address this concern, we re-estimate our main models using only data for men whose highest educational qualification is an apprenticeship. This relatively homogeneous 
group represents about $60 \%$ of our overall sample and has a censoring rate of about $9 \%$ per year. Over the 1985-2009 sample period wage inequality for apprentice-trained men rose substantially, though not as much as over the labor force as a whole, reflecting a widening of education-related wage gaps (see below). Specifically, between interval 1 and interval 4 the standard deviation of log wages for apprentice-trained men rose from 0.328 to 0.388 an $18 \%$ rise - versus the $35 \%$ increase for all full time men.

Appendix Tables 4 and 5 summarize the estimation results for this subsample, using the same format as Tables 2 and 3. In brief, the results are qualitatively very similar to the results for the entire sample. Specifically, the rise in wage inequality is attributed to a rise in the variability of the person-specific component of pay, a rise in the variability of the establishment-level component, and a rise in their covariance. We infer that our main conclusions are robust to our procedure for handling censoring in the Social Security earnings data.

\section{Decomposing Between-Group Wage Differentials}

Germany, like the U.S., has experienced substantial increases in the wage gaps between groups of workers with different skill characteristics. The model in (1) allows a simple decomposition of between-group wage gaps into a component attributable to the time invariant characteristics of workers, a component attributable to the time invariant characteristics of the establishments at which they work, and a component reflecting the mean values of the time-varying observables. Consider a discretely valued time invariant worker characteristic $G_{i}$. From (1) and (4), the mean wage for workers in group $g$ can be written:

$$
E\left[y_{i t} \mid G_{i}=g\right]=E\left[\alpha_{i} \mid G_{i}=g\right]+E\left[\psi_{\boldsymbol{J}(i, t)} \mid G_{i}=g\right]+E\left[x_{i t}^{\prime} \beta \mid G_{i}=g\right] .
$$

Using this framework, the change in the mean wage difference between any two groups $g_{1}$ and $g_{2}$ can be decomposed into a component due to differential changes in the permanent skill characteristics of workers in the two groups, a component due to differential changes in the average establishment wage premium earned by the two groups, and a component due to different evolutions of their time varying characteristics. Such a decomposition is particularly interesting in light of the evidence provided so far of increased assortativeness in the matching of workers to workplaces, which may strongly influence between group wage gaps. 


\section{Education}

Table 4 conducts such a decomposition for changes in the relative mean wages of education groups in West Germany between the first and fourth intervals. (We assign the modal value of observed education to men in each interval). Column 1 of the table shows the change in the relative wages of each group relative to men with apprenticeship training: note that the less educated groups' relative wages have fallen, while the more educated groups' have risen. Columns 2 and 3 show the relative changes in mean person and establishment effects (again, relative to apprentice-trained workers), while column 4 shows the remaining component. The striking conclusion from this decomposition is that nearly all the rise in relative mean wages of workers with university-level training is due to changes in their relative establishment effects. Put differently, the increasing returns to different levels of education in Germany are driven primarily by changes in the quality of the jobs different education groups can obtain, rather than to changes in the value of skills that are fully portable across jobs.

Figure 12 provides an alternative depiction of this decomposition. The horizontal axis shows the mean person effect in the education group in an interval relative to apprentices, while the vertical axis shows the mean establishment effect in the education group in an interval relative to apprentices. We plot the data for interval one (squares) and interval four (diamonds), along with OLS fits summarizing the degree of sorting of higher education groups to better-paying establishments in the two intervals. Notice first that the variation across groups in mean person effects is nearly constant across intervals, with only a slight increase in the mean person effect of university graduates. The variation in mean establishment effects, however, widens substantially between interval 1 and interval 4, implying a rise in education-related wages gaps over time.

An alternative decomposition, first proposed by Mundlak (1978), provides complementary evidence on these patterns while avoiding the complexity of the AKM estimation methodology. Specifically, consider a series of cross sectional regressions of earnings $\left(y_{i t}\right)$ on year of years of schooling attainment $\left(S_{i}\right)$ of the form:

$$
y_{i t}=c_{t}+r_{t} S_{i}+u_{i t}
$$

where the error $u_{i t}$ includes an establishment-level component:

$$
u_{i t}=\mu_{\mathbf{J}(i, t) t}+v_{i t} .
$$

The term $\mu_{\mathbf{J}(i, t) t}$ captures any general effect of working at establishment $j$ in period $t$ that is shared by all workers, regardless of education. Ignoring this group component in estimation 
of (5) will yield a population regression coefficient:

$$
r_{t}^{M} \equiv \frac{\operatorname{Cov}\left(y_{i t}, S_{i}\right)}{\operatorname{Var}\left(S_{i}\right)}=r_{t}+\lambda_{t} b_{t}
$$

where $b_{t} \equiv \frac{\operatorname{Cov}\left(\bar{S}_{\mathbf{J}(i, t) t}, S_{i}\right)}{\operatorname{Var}\left(S_{i}\right)}$ is the educational sorting index plotted in Figure 5 , and $\lambda_{t} \equiv$ $\frac{\operatorname{Cov}\left(\mu_{\mathbf{J}(i, t) t}, \bar{S}_{\mathbf{J}(i, t) t}\right)}{\operatorname{Var}\left(\bar{S}_{\mathbf{J}(i, t) t}\right)}$ is the coefficient from a regression of the establishment effect on mean schooling at the establishment. Thus, the standard (Mincerian) return to schooling in each year $\left(r_{t}^{M}\right)$ consists of three distinct components: the return to schooling conditional on job quality $\left(r_{t}\right)$, the return to mean establishment schooling $\left(\lambda_{t}\right)$, and the association between worker and establishment schooling $\left(b_{t}\right)$. Using the arguments in Mundlak (1978), we may directly estimate each of these components by fitting regressions of the form: ${ }^{41}$

$$
y_{i t}=c_{t}+r_{t} S_{i}+\lambda_{t} \bar{S}_{\mathbf{J}(i, t) t}+\omega_{i t}
$$

As shown in Figure 13 (and previously in Figure 5), the educational sorting index $b_{t}$ is rising over time. Moreover, the return to mean establishment schooling $\lambda_{t}$ is also rising over time, from a value of around 0.04 in the mid-1980s to a value of 0.11 in the late $2000 \mathrm{~s}^{42}$ In contrast, the return to individual schooling $r_{t}$ is actually decreasing slightly over time. Thus, the $20 \%$ rise in the Mincerian return to schooling for West German men between 1985 and 2009 is driven by a combination of increasing returns to working with well-educated coworkers, coupled with a rise in the segmentation of education groups across establishments. Confirmation of the findings in Table 4 with this simple alternative decomposition gives us further confidence that an important share of rising wage inequality in Germany is due to increasing workplace heterogeneity in pay, coupled with rising assortativeness in the matching of workers to establishments.

\section{Occupation}

Autor, Levy, and Murnane's (2003) seminal study of technological change and task prices has led to renewed interest in the study of the occupational wage structure. ${ }^{43}$ Figure $14 \mathrm{a}$ shows the evolution of this structure in West Germany between the late 1980s (interval

\footnotetext{
${ }^{41}$ It can be shown that the OLS estimator of $r_{t}$ in this specification coincides numerically with that resulting from estimation of (5) including establishment fixed effects. Thus, our estimates of $r_{t}$ measure the "within-establishment" returns to schooling.

${ }^{42} \mathrm{We}$ include a quadratic in potential experience in all the models, so the returns to education correspond to the conventional Mincerian returns which hold constant labor market experience.

${ }^{43}$ See Acemoglu and Autor (2011) for a review of the related literature.
} 
1) and the mid/late 2000's (interval 4). ${ }^{44}$ Overall there is a widening of wage differences across occupations, as reflected by the slope of the line relating mean wages in interval 4 to mean wages in interval 1 , which is 1.14 (standard error $=0.03$ ) from unweighted OLS, and 1.27 (0.02) from a regression weighted by initial employment shares. Interestingly, the relationship between wages in the two intervals is, if anything, slightly concave, reflecting declines in real wages for the lowest-wage occupational groups. ${ }^{45}$

Our models provide a new perspective on the changing occupational wage structure by allowing us to decompose the changes in between-occupation wage variation into components due to changes in the variability of workers' characteristics, changes in the variability of establishment characteristics, changes in the sorting of occupation groups to workplaces, and changes in the impacts of the time-varying characteristics. The results are summarized in Panel A of Table 5 which reports the standard deviations across occupations of the various wage components, the correlation of average person and establishment effects, and the variance shares in each interval. In the last column of the table we also show the changes in the variances between interval 1 and interval 4, and the shares of the overall change in variance accounted for by each component.

The estimates suggest that the largest share of the rise in between-occupation inequality $(42 \%)$ is attributable to the rising correlation between person effects and establishment effects. ${ }^{46}$ That is, higher-paid occupations are increasingly concentrated at high-wage establishments, while lower-paid occupations are increasingly concentrated at low-wage establishments. This result complements our earlier finding in Figure 5 that occupational skill groups are increasing segregated at particular establishments. As we discuss in more detail in the next section, one partial explanation for this increasing segregation between high-wage and low-wage occupations is outsourcing, which often involves firms replacing in-house jobs like janitorial services with outside contractors who are classified as working at a separate establishment. This increasing correlation is illustrated in Figure 14b, which plots the mean establishment effects in an occupation against the mean person effect in our first and last intervals.

\footnotetext{
${ }^{44}$ The IEB file includes a 3 -digit occupation code with about 320 categories. In the analysis in this section we assign each worker a single occupation code for each job in each interval, based on the highest code observed in the job during the sample interval.

${ }^{45} \mathrm{In}$ an unweighted regression a quadratic term in initial-period wages is not significant. In a weighted model, however, the quadratic term is negative and significant $(\mathrm{t}=4.7)$.

${ }^{46}$ Because the correlations are calculated across averages of groups of workers in each occupation they do not suffer from the sampling error-induced biases that affect the correlations at the individual level, discussed in the Appendix.
} 


\section{Industry}

The bottom panel of Table 5 provides a parallel decomposition of the variability in mean wages across industries. ${ }^{47}$ A large literature (e.g., Krueger and Summers, 1988; Katz and Summers, 1989) has examined the between-industry structure of pay differences. A stillunresolved issue is the extent to which industry-specific wage premia are attributable to unobserved differences in worker quality (Murphy and Topel, 1990; Gibbons and Katz, 1992; Goux and Maurin, 1999; Gibbons et al., 2005) versus firm-specific pay policies like efficiency wages. Our additive effects framework suggests that both components are important. In the 1985-91 interval, for example, variation in mean worker effects explains about 35\% of between-industry wage variation, variation in establishment effects explains a similar share, and their covariance adds another $20 \%$. As shown in column 5 of the table, rising dispersion in worker quality explains a sizeable share (about $44 \%$ ) of the rise in the variance of wages across industries, while rising dispersion in establishment pay premiums contributes another $19 \%$. As with the between-occupation wage structure, however, a relatively large share $(42 \%)$ is due to the increasing sorting of high-wage workers to high-wage plants.

\section{Rising Establishment Heterogeneity: Cohort Effects and Collective Bargaining Status}

The increasing variability in establishment-level pay premiums between the first and last intervals of our sample raises the question of whether this rise was generated by a divergence in the pay premiums offered by continuing establishments, by a change in the policies of newly created establishments, or by a combination of the two. To investigate this question, we assigned each establishment a birth year based on the first year it appears in our sample. We then calculated a variety of statistics for establishments in different birth cohorts. As shown in Appendix Table 6, about 950,000 establishments are present in the first year of our sample (1985), and another 100,000 or so are born each year. Mean wages of workers at new establishments move in parallel to average wages for all workers from 1986 to 1996, but exhibit a downward relative trend after 1996. The standard deviation of wages among workers at new plants is also relatively stable until the late 1990s, then begins to rise.

The fall in average wages at new establishments and the rise in wage dispersion among employees at these plants are both suggestive of an important cohort pattern in the evolution

\footnotetext{
${ }^{47}$ The IEB file using a changing set of industry codes. We develop a crosswalk by comparing the industry codes assigned to the same establishment in adjacent years under the different coding systems. To simplify the crosswalk we use a 2-digit level of classification, with 96 categories.
} 
of establishment pay inequality. These simple comparisons, however, do not control for potential changes in the characteristics of the workers at new establishments. To address this concern we plot the standard deviations of the estimated establishment effects by birth cohort in Figure 15. Note that establishments born relatively early in our study period are assigned up to four different establishment effects, depending on how long they survive. For example, establishments born in 1988 have a 0.26 standard deviation in their interval-1 effects (estimated using data from 1985 to 1991), a 0.22 standard deviation in their interval-2 effects (estimated using 1990-96 data), a 0.22 standard deviation in their interval-3 effects (estimated using 1996-2002 data), and a 0.24 standard deviation in their interval-4 effects (estimated using 2002-2009 data).

Consideration of the standard deviations plotted in Figure 15 suggests three main conclusions. First, there appears to be a systematic lifecycle pattern in the measured heterogeneity of firms. The distribution of establishment effects is relatively wide for recently-born establishments but tends to narrow and then stabilize over time. This is particularly true for plants born in the last year or two of an interval (e.g., plants born in 1990 and 1991 have relatively large dispersion in their interval-1 effects). In part this may reflect additional noise in the estimated establishment effects for plants that are only observed in one or two years. Second, among continuing establishments there is not much rise in the variability of firm effects between interval 1 and interval 4 . This is perhaps clearest for the (large) set of establishments that are first observed in 1985. Among these establishments, the standard deviation of estimated effects only rises from 0.15 in interval 1 to 0.17 in interval 4 . Finally, much of the rising heterogeneity in establishments appears to be due to "new" establishments, particularly those that first appear after 1996. Adjusting for lifecycle effects, establishments born in the late 2000s have about $25 \%$ higher standard deviations in their establishment effects than those born before 1996.

What features of new establishments - particularly those formed after 1996 - account for the extra variability in their wage premiums? One potential factor is collective bargaining status. Wages set under collective bargaining are less disperse in Germany (e.g., Dustmann et al, 2009; Antonczyk et al., 2010), although existing research has not addressed the extent to which this association is driven by selection into coverage. ${ }^{48}$ To gather some evidence on the impact of collective bargaining we use information on the (relatively small) panel of establishments in the IAB's Linked Employer Employee data (LIAB) that can be merged to our analysis sample. ${ }^{49}$ Information is available in the LIAB since 1995 on whether an

\footnotetext{
${ }^{48}$ Gürtzgen (2007) suggests that a substantial fraction of the observed differences in mean wages between workers in different collective bargaining arrangements is due to selectivity.

${ }^{49}$ See Alda, Bender, and Gartner (2005) for a description of the LIAB data base. The LIAB has about 13,000-14,000 establishments in the years after 2000, and a smaller sample in earlier years.
} 
establishment has signed on to the appropriate sector-level contract, has negotiated a plantspecific collective bargaining agreement, or has chosen not to participate in any form of collective bargaining. We use this information in two ways. First, we compare the distributions of establishment effects for plants in each of the three possible collective bargaining categories. Second, we form an estimate of the fraction of establishments from each birth cohort in each category.

Figure 16 shows the distribution of interval-3 establishment effects for plants in the LIAB that can be linked to our sample, classified by their collective bargaining status in 2000 . We show the fractions of establishments with wage premiums in each of 10 decile groups. ${ }^{50}$ This simple figure illustrates a very striking difference between establishments with either a sectoral or plant-specific agreement, and those without any form of collective bargaining coverage. Whereas $22 \%$ of establishments with some form of coverage are in the first two decile groups, $44 \%$ of uncovered establishments fall into this range. This relative left skew is associated with a substantially lower $(-10 \%)$ mean establishment effect for plants in the LIAB with no collective bargaining relative to plants with either form of bargaining. ${ }^{51}$ The distributions of establishment effects are similar for other years in which we can link our estimated establishment effects to coverage information from the LIAB. In all cases the distributions of establishment effects for uncovered establishments exhibit strong left skew relative to covered establishments, and have a mean that is 8-10 percent lower.

The fraction of West German workers whose wages are set by collective bargaining has fallen sharply since the mid-1990s (see Dustmann et al, 2009, Table III). This decline is particularly pronounced for new establishments. The top line in Figure 15 shows the estimated fraction of establishments from different birth cohorts with some form of collective bargaining. ${ }^{52}$ This fraction has fallen from 50-55\% for establishments born from 1986 to 1996, to $30 \%$ or less for establishments born after 2007. Interestingly, the trend in coverage seems to exhibit a turning point at about the same time (circa 1996) as the trend in the standard deviation of estimated establishment effects. This coincident timing is consistent with the implication from Figure 16 that a rise in the fraction of uncovered establishments would be expected to lead to a rise in the overall dispersion of establishment effects. Of course, it

\footnotetext{
${ }^{50}$ The decile cutoffs for the establishment effects are formed so that 10 percent of person-year observations in our third sample interval (1996-2002) fall into each decile. Establishments in the LIAB are relatively large and on average have more positive establishment effects than the population as a whole.

${ }^{51}$ In a regression of the interval-3 establishment effect on dummies for a sectoral or plant-specific agreement, the coefficients are 0.100 (standard error $=0.05$ ) for a sectoral agreement and 0.097 (standard error $=0.01$ ) for a plant-specific agreement. The coefficients are 0.080 and 0.085 respectively when dummies are added for the birth cohort of the establishment.

${ }^{52}$ We first estimate the coverage rate by birth year for establishments in our sample that can be merged to the LIAB, using coverage data for each year from 1999-2008. We then take the average coverage rate across years for each birth cohort.
} 
is difficult to assign a causal role to collective bargaining, since firms endogenously choose whether to adopt some form of collective bargaining, or not. At a minimum, however, the evidence in Figures 15 and 16 suggests a proximate role for declining collective bargaining coverage among establishments that have begun operation since the mid-1990s in the rise in establishment-level heterogeneity.

\section{Establishment Effects and the Survival of Establish- ments and Jobs}

One possible source of the rising variability in establishment effects is increasing variability in rents that are partially shared by workers. Indeed, there is an extensive literature suggesting that more profitable firms offer higher wages (e.g., van Reenan, 1996; Arai, 2003; Guiso et al., 2005; Gürtzgen, 2010, Card et al., 2010). If rent sharing is the primary source of establishment-level wage differentials, we expect higher-wage establishments to be successful and profitable enterprises. An alternative explanation is that some (newer) firms have been able to break free from overly generous sectoral wage contracts. This hypothesis suggests that lower-wage establishments are in fact more likely to be successful and earn higher profits.

We lack data on profitability, but an indirect test of these competing hypotheses is provided by comparing the survival probabilities of high wage and low wage establishments. Figure 17a shows empirical survivor functions by quartile of estimated establishment effects for the cohort of establishments that first appear in 1989. The data clearly indicate that high wage establishments are more likely to survive than low wage establishments, suggesting that some form of rent sharing may be going on. These patterns are confirmed for a broader set of cohorts in results from probit models for the likelihood of surviving for $5+$ or $10+$ years, and Tobit models for the duration of establishment life, presented in Appendix Table 7. We estimate the models separately for establishments born in different intervals, and include the estimated establishment effect, the mean person effect for all employees at the establishment, and controls for establishment size, average education of workers, and year of "birth". These models confirm that establishments that offer higher wage premiums survive longer, as do those that employ higher-wage workers.

Additional insight is provided by looking at the survival of jobs at higher- versus lowerwage establishments. If the wage premium paid by high-wage establishments is a rent, we would expect employees at these plants to be less likely to quit, and for their jobs to last longer. If, on the other hand, the wage premium is a compensating differential for longer hours or more intense work effort, we would not expect much relationship between 
job duration and the size of the establishment effects. Figure 17b shows estimated survivor functions for jobs created in 1989 at establishments in each of the four quartiles of estimated effects. Again, it is clear that jobs at higher wage establishments are more likely to survive. ${ }^{53}$ This conclusion is confirmed by a series of probit and Tobit models, presented in Appendix Table 8. Controlling for an individual's person effect, his education, and the size of the establishment, jobs at higher-wage establishments last much longer.

Taken together, the patterns of establishment and job survival suggest that establishments that offer higher average wages are more profitable, and share some of these profits with workers. This is in keeping with the results of several studies of the French labor market, which provide direct evidence that firms with higher wage premiums in an AKM-based analysis are also more profitable (e.g. Abowd, Kramarz, and Margolis, 1999; Goux and Maurin, 1999; Abowd and Kramarz, 2005). Whether, in Germany, trends in these profits are driven by proprietary technological advantages, particular product niches, or other factors is clearly an important topic for future research.

\section{Conclusions}

West Germany has experienced substantial changes in the structure of wages over the past 25 years. Observers have been divided over whether those changes are driven primarily by technological changes or changes in labor market institutions (Dustmann et al., 2009; Eichhorst, 2012). Our analysis approaches this question from a different perspective, asking whether the proximate source of changes in the structure of wages involves the portable component of wages, or the component associated with which particular employer a worker is paired. The data reveal that both components are increasingly important - the gap between consistently high and low wage workers has grown, as in traditional one-factor models of skill pricing (Juhn, Murphy, and Pierce, 1993), but the gap between good and bad jobs has also grown, suggesting that job search and matching is an increasingly high stakes process one that appears to be increasingly mediated through the education system.

We find that the distribution of establishment effects varies substantially by firm cohort, with newer firms exhibiting greater variance, and being less likely to participate in collective bargaining. These patterns could be the result of differences in technology choices or management practices (Bloom and Van Reenen, 2007) across cohorts of firms, changes in outsourcing behavior or institutional factors that limit the ability of older firms to abandon

\footnotetext{
${ }^{53}$ In our sample only about $20 \%$ of job endings occur because of establishment death. Thus, the finding that jobs last longer at higher-paying establishments is not simply a reflection of the fact that these establishments live longer.
} 
existing wage bargains. We also find that higher wage establishments are more likely to survive and have lower separation rates suggesting that some form of rent sharing underlies our results.

These findings raise many questions regarding the nature of modern labor markets. Are the patterns uncovered here present in other developed economies? Which factors drive the matching of workers to firms? Why are there large firm cohort effects in wages? How much of the displacement effects of job loss are due to establishment effects? How do shocks to the product market filter into changes in person and firm effects? With the proliferation

of modern employer-employee datasets, we are hopeful that progress can be made on these important questions.

\section{Appendix}

\section{IEB Data}

Our basic data source is the Integrated Employment Biography (IEB) database. The IEB consists of information on employment spells at a given establishment (or firm) within a calendar year, taken from notices of employment filed by the employer. Each notice of employment has a beginning date (e.g., January 1), an end date (e.g., December 31), the average daily wage earned by the employee (censored at the Social Security maximum earnings level), indicators for the legal status of the job (including whether the job is full time or part time and whether the job is a "marginal job" subject to reduced Social Security taxes), as well as information on the gender, birth date, educational qualification and occupation of the worker, and the industry and geographic location of the establishment.

We process the data in two steps. First, we collapse all spells at the same employer in a given year into a single person-firm-year record, summing total earnings at each employer. Row 1 of Appendix Table 1a shows the number of spell records in the IAB data file for full-time male employees age 20-60 working in non-marginal jobs in 1985 (the first year of our sample), 1997 (the middle year of our sample) and 2009 (the last year). Row 2 shows the number of person-firm-year records: on average there are about 1.06 spells per person-firm-year in the early years of our sample, rising slightly to 1.11 spells per person-firm-year in 2009 (see row 4).

In the second step we select one observation per person per year by selecting the person-firm record with the highest total earnings in a given year (and excluding any observation with a daily wage $<10$ Euros). On average each person has about 1.1 different employers per year, with no trend over our sample period (see row 5). Line 3 of Appendix Table 1a shows the number of person-year observations in our final data set. 
Appendix Table 1b presents some summary statistics for our final sample, including the number of person observations in each year (which ranges from 11.9 to 14 million), average real annual earnings and real daily wage, and the mean and standard deviation of the log of daily wages. We use the consumer price index with a $1995=100$ base to deflate all nominal values.

In the IEB data, education is coded into 6 categories, plus a missing or undetermined category. We group these into 5 classes: (1) missing; (2) primary/lower secondary or intermediate school leaving certificate, or equivalent, with no vocational qualification; (3) primary/lower secondary or intermediate school leaving certificate, or equivalent, with a vocational qualification (4) upper secondary school certificate ("Arbitur") with or without a vocational certificate; (5) degree from Fachhochschule or university. For simplicity we refer to the third category as "apprentices" and the fifth category as "university graduates". For an individual who is observed in multiple notifications from the same employer in the same year we assign the highest education category for that personfirm-year observation. For our analysis based on the AKM specification, we assign the modal education category observed for an individual in the years he is at the same job.

In the IEB data, each job notification includes information on occupation and industry. For an individual who is observed in multiple notifications from the same employer in the same year we assign the highest occupation category and the highest industry category for that person-firm-year observation. For our analysis based on the AKM specification, we assign the highest occupation category observed for an individual in the years he is at the same job as occupation, and the highest industry code observed for the establishment in the years the establishment is present in the data.

\section{Tobit imputations}

As shown in Appendix Figure 2, 9 to 14 percent of person-year observations in our data set have average daily wages that are censored at the Social Security maximum. We follow Dustmann et al. (2009) and fit a series of Tobit models to log daily wages. We then impute an uncensored value for each censored observation using the estimated parameters of these models and a random draw from the associated (left- censored) distribution. ${ }^{54}$

Since we are fitting models that include both a person and year effect, we want the imputation model to reflect individual and job-specific components of the wage. We therefore construct, for each individual in each year, the mean of his log wage in all other periods, and the fraction of other years that the individual's wage is censored. For individuals who are only observed in one year, we set the mean log wage in other years to the sample mean, and the fraction of censored wages in other years equal to the sample mean, and include a dummy in the model for those who are

\footnotetext{
${ }^{54}$ Specifically, we impute an upper tail as follows. Suppose that the estimated Tobit model for $y$ (the log of wages) has $y \sim N\left(X^{\prime} \beta, \sigma\right)$, and consider a censored observation, such that $y \geq c$, where $c$ is the censoring point. Let $k=\Phi\left[\left(c-X^{\prime} \beta\right) / \sigma\right]$, where $\Phi$ represents the standard normal density, and let $u \sim U[0,1]$ represent a uniform random variable. Then we impute an uncensored value for $y$ as: $y^{u}=X^{\prime} \beta+\sigma \Phi^{-1}[k+u \times(1-k)]$.
} 
observed only once. We also construct the mean log wage for the individual's co-workers in the current year (i.e., the "leave out mean" of log wages at his employer) and the fraction of co-workers who are censored in the current year (the "leave out mean" of the censoring rate at his employer). For individuals who work at an establishment with only 1 full time male employee we set the mean log wage for co-workers equal to the sample mean, and the fraction of co-workers with censored wages equal to the sample mean, and include a dummy in the model for employees of 1-worker firms.

We then fit a series of 500 Tobit models separately by year, education ( 5 values: missing; no qualification; apprenticeship; some post secondary; and university graduate), and 10 year age range (20-29; 30-39; 40-49; 50-60), including the following variables: age; mean log wage in other years; fraction of censored wages in other years; number of full time male employees at the current firm and its square, dummy for 11 or more employees, mean years of schooling and fraction of university graduates at the current firm, mean log wage of co-workers and fraction of co-workers with censored wages, dummy for individuals observed only 1 year between 1985 and 2009; dummy for employees of 1-worker firm. Appendix Table 2 shows the coefficient estimates for models for 40-49 year old apprentices in 1985, 1997, and 2009.

Appendix Figure 2 shows the gaps between the mean and standard deviation of log wages when we use the imputed values for censored observations and when we do not. The use of imputed values leads to a 0.02-0.04 higher value for the mean log wage, and a 0.03 to 0.06 higher value for the standard deviation of log wages. The gaps are particularly notable in 1992 and 2002, when the censoring rate was relatively high.

\section{Computation}

Because our dataset is very large and identification of the establishment effects derives entirely from movers, we conducted estimation in two steps. First, in each interval, we extracted the sample of workers who switched establishments over the relevant time period. We fit the model to this sample of movers and recovered the estimated vector of establishment effects $\widehat{\psi}$ along with the coefficients $\widehat{\beta}$ corresponding to the time varying covariates $x_{i t} .{ }^{55}$ Then, for each worker who stayed at the same establishment over the sample interval, we computed an estimate of his person effect as follows:

$$
\widehat{\alpha}_{i}=\frac{1}{T_{i}} \sum_{t} d_{i t}\left(y_{i t}-\widehat{\psi}_{J(i, t)}-x_{i t}^{\prime} \widehat{\beta}\right)
$$

\footnotetext{
${ }^{55}$ This yields an inefficient estimator of $\beta$. However, in a sample of roughly 90 million observations, precision is not a major concern. A separate issue is that our two step procedure only ensures orthogonality between the AKM residuals $\widehat{r}_{i t}$ and $x_{i t}$ in the sample of movers. In practice, the correlation in the sample of establishment stayers between $x_{i t}^{\prime} \widehat{\beta}$ and the AKM residuals is very small in each interval, with the largest correlation occuring in interval 3 and amounting to approximately -.01.
} 
where $T_{i} \equiv \sum_{t} d_{i t}$ is the number of periods that individual $i$ is observed in the sample interval. Our root mean squared error calculations were conducted by reducing the degrees of freedom by one for each connected stayer mean estimated. ${ }^{56}$

Our estimation tasks were performed in Matlab. Code for our analysis is available online. We used a variant of the depth first search algorithm implemented in the open source matlabBGL package to find the largest connected set of establishments in each data interval. The design matrices $[D, F, X]$ were stored as sparse matrices. To compute the least squares solutions we solved the normal equations in (3) using Matlab's preconditioned conjugate gradient routine (see Shewchuck (1994) for a lucid introduction). To speed the process we used an incomplete Cholesky factorization of $Z^{\prime} Z$ as the preconditioner with threshold dropping tolerance of 0.01 .

\section{Bias in the estimated covariance matrix of person and establishment effects}

It is well known that sampling errors in the estimated person and establishment effects may lead to inflated estimates of the standard deviation of each component and negatively biased estimates of the covariance between the person and establishment effects. This has led some authors (e.g., Andrews et al., 2008) to propose parametric bias corrections to the estimated components. To illustrate the logic of such an approach, and the difficulties involved, we denote the population quantities of interest as:

$$
\begin{aligned}
\sigma_{D \alpha}^{2} & \equiv \frac{1}{N^{*}-1} \alpha^{\prime} D^{\prime} Q_{1} D \alpha \text { (Variance of person effects) } \\
\sigma_{F \psi}^{2} & \equiv \frac{1}{N^{*}-1} \psi^{\prime} F^{\prime} Q_{1} F \psi(\text { Variance of establishment effects) } \\
\sigma_{D \alpha, F \psi} & \equiv \frac{1}{N^{*}-1} \psi^{\prime} F^{\prime} Q_{1} D \alpha(\text { Covariance of person and establishment effects) }
\end{aligned}
$$

where $Q_{1} \equiv I-1\left(1^{\prime} 1\right)^{-1} 1^{\prime}$ is a symmetric demeaning matrix.

OLS estimation of (2) yields a coefficient vector:

$$
\widehat{\xi}=\xi+\left(Z^{\prime} Z\right)^{-1} Z^{\prime} r
$$

\footnotetext{
${ }^{56}$ That is we used the formula $R M S E=\sqrt{\frac{S S R}{d o f}}$ where $S S R$ is the sum of squared residuals across all person-year observations in the interval and dof $=N^{*}-N-(J-1)-\operatorname{rank}(X)$, where $N^{*}$ is the number of person year observations including the stayers, $N$ is the number of connected individuals including the stayers, and $J$ is the number of connected establishments.
} 
with $E\left[\left(Z^{\prime} Z\right)^{-1} Z^{\prime} r\right]=0$. The sampling variance of this vector can be written:

$$
\begin{aligned}
V_{\widehat{\xi}} & \equiv E\left[(\widehat{\xi}-\xi)(\widehat{\xi}-\xi)^{\prime}\right] \\
& =\left(Z^{\prime} Z\right)^{-1} Z^{\prime} \Omega Z\left(Z^{\prime} Z\right)^{-1}
\end{aligned}
$$

where $\Omega \equiv E\left[r r^{\prime}\right]$ is the $N^{*} \times N^{*}$ variance covariance matrix of the errors.

The sample analogues to the population quantities can be expressed in terms of the following quadratic forms:

$$
\begin{aligned}
\widehat{\sigma}_{D \alpha}^{2} & \equiv \frac{1}{N^{*}-1} \widehat{\xi}^{\prime} A_{D \alpha} \widehat{\xi} \\
\widehat{\sigma}_{F \psi}^{2} & \equiv \frac{1}{N^{*}-1} \widehat{\xi}^{\prime} A_{F \psi} \widehat{\xi} \\
\widehat{\sigma}_{D \alpha, F \psi} & \equiv \frac{1}{N^{*}-1} \widehat{\xi}^{\prime} A_{D \alpha, F \psi} \widehat{\xi}
\end{aligned}
$$

where $A_{D \alpha} \equiv\left[\begin{array}{ccc}D^{\prime} Q_{1} D & 0 & 0 \\ 0 & 0 & 0 \\ 0 & 0 & 0\end{array}\right], A_{F \psi} \equiv\left[\begin{array}{ccc}0 & 0 & 0 \\ 0 & F^{\prime} Q_{1} F & 0 \\ 0 & 0 & 0\end{array}\right], A_{D \alpha, F \psi} \equiv\left[\begin{array}{ccc}0 & F^{\prime} Q_{1} D & 0 \\ 0 & 0 & 0 \\ 0 & 0 & 0\end{array}\right]$.

Unbiasedness of OLS and standard results on quadratic forms imply that for any matrix $A$,

$$
E\left[\widehat{\xi}^{\prime} A \widehat{\xi}\right]=\xi^{\prime} A \xi+\operatorname{tr}\left(A V_{\widehat{\xi}}\right)
$$

Therefore the bias in our estimates of the variance components corresponds to the trace term in the above expression, which in turn depends critically upon $V_{\widehat{\xi}}$. Previous work has focused on evaluating this bias expression under the assumption that the $r$ are independent and identically distributed in which case $\Omega=I \sigma^{2}$ and $V_{\widehat{\xi}}=\left(Z^{\prime} Z\right)^{-1} \sigma^{2}$.

Unfortunately, the bulk of the literature on earnings dynamics (MaCurdy, 1982; Abowd and Card, 1989; Meghir and Pistaferri, 2004) suggests a substantially more complicated error structure of earnings with complex forms of temporal dependence and heteroscedasticity. Errors in modeling the structure of $\Omega$ will induce errors in estimation of $V_{\widehat{\xi}}$ which is why, at least since the work of White (1980), economists have sought robust variance estimates that don't rely upon estimation of all elements of $\Omega$. Unfortunately, robust variance estimation is not possible in our setting because the estimates $\widehat{\xi}$, while unbiased, are not consistent.

In unreported results we have attempted parametric corrections allowing for a match component and a moving average component to the errors $r$. These corrections yielded small changes in the estimated variance-covariance matrix $\widehat{V}_{\widehat{\xi}}$ and had trivial effects on the trends of the various components. In sampling experiments we found the corrections to provide a poor guide to the 
degree of bias created by working with subsamples of the data. We suspect this is because our model for the errors is insufficiently rich - a problem we are unlikely to be able to solve in a convincing way. For this reason, our estimates in section 7 are of particular interest because these results are based upon group averages involving tens of thousands (or in some cases millions) of observations, in which case biases due to sampling error become largely irrelevant.

\section{References}

1. Abowd, John and David Card. 1989. "On the Covariance Structure of Earnings and Hours Changes." Econometrica 57(2): 411-445.

2. Abowd, John, Francis Kramarz, and David Margolis. 1999. "High Wage Workers and High Wage Firms." Econometrica 67(2): 251-333.

3. Abowd, John, Robert Creecy, and Francis Kramarz. 2002. "Computing Person and Firm Effects Using Linked Longitudinal Employer-Employee Data.” Working paper.

4. Abowd, John and Francis Kramarz. 2005. "Human Capital and Worker Productivity: Direct Evidence from Linked Employer-Employee Data." Annals of Economics and Statistics 79/80: 323-338.

5. Abraham, Katherine and Susan Taylor. 1996. "Firms' Use of Outside Contractors: Theory and Evidence." Journal of Labor Economics 14(3): 394-424.

6. Acemoglu, Daron, Philippe Aghion, Claire Lelarge, John Van Reenen, and Fabrizio Zilibotti. 2007. "Technology, Information, and the Decentralization of the Firm." Quarterly Journal of Economics 122(4): 1759-1799.

7. Acemoglu, Daron and David Autor. 2011. "Skills, Tasks, and Technologies: Implications for Employment and Earnings" in Handbook of Labor Economics eds. Ashenfelter and Card, Vol. IV, Part B, 1043-1171.

8. Akerlof, George. 1982. "Labor Contracts as Partial Gift Exchange." Quarterly Journal of Economics 97(4): 543-569.

9. Alda, Holger, Stefan Bender, and Hermann Gartner (2005). "The linked Employer-employee Dataset Created from the IAB Establishment Panel and the Process-Produced Data of the IAB (LIAB)." Schmollers Jahrbuch 125 (2): 327-336.

10. Andersson, Fredrik, Elizabeth Davis, Julia Lane, Brian McCall, and Kristin Sandusky. 2012. "Decomposing the Sources of Earnings Inequality: Assessing the Role of Reallocation." Industrial Relations, forthcoming. 
11. Andrews, M.J., L. Gill, T. Schank, and R. Upward. 2008. "High wage workers and low wage firms: negative assortative matching or limited mobility bias?" Journal of the Royal Statistical Society 171(3): 673-679.

12. Antonczyk, Dirk, Bernd Fitzenberger, and Katrin Sommerfeld 2010. "Rising Wage Inequality, the Decline of Collective Bargaining, and the Gender Wage Gap." Unpublished Working Paper, University of Freiburg, April 2010.

13. Arai, Mahmood. 2003. "Wages, Profitability and Capital Intensity: Evidence from Matched Worker-Firm Data." Journal of Labor Economics 21 (3): 593-618.

14. Ashenfelter, Orley C. 1978. "Estimating the Effect of Training Programs on Earnings." Review of Economics and Statistics 60(1): 47-57.

15. Autor, David H. 2009. "Introduction to Studies of Labor Market Intermediation." In David H. Autor, editor, Studies in Labor Market Intermediation. Chicago: University of Chicago Press.

16. Autor, David H., Lawrence H. Katz, and Melissa S. Kearney. 2008. "Trends in U.S. Wage Inequality: Revising the Revisionists." Review of Economics and Statistics 90(2): 300-323.

17. Autor, David H., Lawrence H. Katz, and Alan B. Krueger.1998. "Computing Inequality: Have Computers Changed the Labor Market?" Quarterly Journal of Economics. 113(4): 1169-1214.

18. Autor, David H., Frank Levy, and Richard J. Murnane. 2002. "Upstairs, Downstairs: Computers and Skills on Two Floors of a Large Bank," Industrial and Labor Relations Review, LV: $432-447$.

19. Autor, David H., Frank Levy, and Richard J. Murnane. 2003. "The Skill Content of Recent Technological Change: An Empirical Exploration," Quarterly Journal of Economics. 118(4): $1279-1334$.

20. Bachmann, Ronald, Marion König, and Sandra Schaffner 2012. "Lost in Transition? Minimum Wage Effects on German Construction Workers." Ruhr Economic Papers \#358, July 2012 .

21. Bagger, Jesper, Kenneth Sorensen, and Rune Vejelin. 2012. "Wage Sorting Trends.” working paper..

22. Barth, Erling, Alex Bryson, James Davis, and Richard Freeman. 2011. "The Contribution of Dispersion across Plants to the Increase in US Earnings Dispersion." Working paper. 
23. Bauer, Thomas and Klaus F. Zimmermann. 1999. "Occupational Mobility of Ethnic Migrants." IZA Discussion Paper \#58.

24. Bernard, Andrew and Bradford Jensen. 1995. "Exporters, Jobs, and Wages in US Manufacturing: 1976-87." Brookings Papers on Economic Activity: Microeconomics. 67-112.

25. Bernard, Andrew, Jonathan Eaton, Bradford Jensen, and Samuel Kortum. 2003. "Plants and Productivity in International Trade.” American Economic Review 93(4): 1268-1290.

26. Bound, John, and George Johnson. 1992. "Changes in the Structure of Wages in the 1980s: An Evaluation of Alternative Explanations," American Economic Review 82(3):371-392.

27. Bloom, Nicholas and John Van Reenen. 2007. "Measuring and Explaining Management Practices Across Firms and Countries." Quarterly Journal of Economics 122(4): 1351-1408.

28. Brown, Charles. 1980. "Equalizing Differences in the Labor Market." Quarterly Journal of Economics 94(1): 113-134.

29. Burda, Michael. 1993. "The determinants of East-West German migration: Some first results." European Economic Review 37(2-3): 452-461.

30. Burda, Michael and Jennifer Hunt. 2011. "What Explains the German Labor Market Miracle in the Great Recession?" Brookings Papers on Economics Activity 42(1): 273-335.

31. Cahuc, Pierre, Fabien Postel-Vinay, and Jean-Marc Robin. 2006. "Wage Bargaining with On the Job Search: Theory and Evidence." Econometrica 74(2): 323-364.

32. Card, David, Thomas Lemieux, and Craig Riddell. 2004. "Unions and Wage Inequality." Journal of Labor Economics 25(4): 519-562.

33. Card, David, Francesco Devicienti, and Agata Maida. 2010. "Rent-Sharing, Holdup, and Wages: Evidence from Matched Panel Data." NBER Working Paper \#16192.

34. Cardoso, Ana. 1997. "Workers or Employers: Who is Shaping Wage Inequality?" Oxford Bulletin of Economics and Statistics 59(4): 523-547.

35. Cardoso, Ana. 1999. "Firms' Wage Policies and the Rise in Labor Market Inequality: The Case of Portugal." Industrial and Labor Relations Review 53(1): 87-102.

36. Carlsson, Mikael, Julian Messina, and Oskar Nordström Skans. 2011. "Wage Adjustment and Productivity Shocks." Sveriges Riksbank working paper \#253. 
37. Davis, Steven and John Haltiwanger. 1991. "Wage Dispersion between and within U.S. Manufacturing Plants, 1963-86." in Martin Baily and Clifford Winston, eds. Brookings Papers on Economic Activity: Microeconomics pp.115-200.

38. Davis, Steven and Till Von Wachter. 2012. "Recessions and the Costs of Job Loss." Brookings Papers on Economic Activity forthcoming.

39. Dinardo, John, Nicole Fortin, and Thomas Lemieux. 1996. "Labor Market Institutions and the Distribution of Wages, 1973-1992: A Semiparametric Approach.” Econometrica. 64(5): 1001-1044.

40. Dorner, Matthias, Marion König, and Stefan Seth. 2011. "Sample of Integrated Labour Market Biographies - Regional File 1975-2008." IAB FDZ Datenreport 07/2011 EN.

41. Dube, Arindrajit and Ethan Kaplan. 2010. "Does Outsourcing Reduce Wages in the LowWage Service Occupations? Evidence from Janitors and Guards." Industrial and Labor Relations Review 63(2):287-306.

42. Dustmann, Christian, Johannes Ludsteck, and Uta Schönberg. 2009. "Revisiting the German Wage Structure." Quarterly Journal of Economics 124(2): 843-881.

43. Economic Policy Institute (EPI) 2009. The State of Working America. Washington DC: EPI.

44. Eeckhout, Jan and Philipp Kircher. 2011. "Identifying Sorting - In Theory." Review of Economic Studies 78(3): 872-906.

45. Eichhorst, Werner and Paul Marx. 2009. "Reforming German Labor Market Institutions: A Dual Path to Flexibility." IZA Discussion Paper \#4100.

46. Eichhorst, Werner. 2012. "The Unexpected Appearance of a New German Model." IZA Discussion Paper \#6625.

47. Ellguth, Peter, Hans-Dieter Gerner, and Jens Stegmaier. 2012. "Wage bargaining in Germany: The role of works councils and opening clauses." IAB Discussion Paper 5/2012.

48. European Industrial Relations Observatory (EIRO). 1997a. "The Use of Hardship Clauses in East German Metalworking Industry." Available at: http://www . eurof ound .europa.eu . eiro/1997/03/feature/de9703205f .htm 
49. European Industrial Relations Observatory (EIRO). 1997b. "A Copernican U-turn in German collective bargaining?" Available at: http://www.eurofound.europa.eu.eiro/1997/ 06/feature/de9706216f.htm

50. European Industrial Relations Observatory (EIRO). 2007. "Government Sets Minimum Wages for Cleaning Industry." Available at: http://www . eurof ound.europa. eu.eiro/2007/ 03/articles/de0703049i.htm

51. European Industrial Relations Observatory (EIRO). 2012. "Temporary Agencies Granted National Minimum Wage." Available at: http://www.eurofound.europa.eu.eiro/2012/ 02/articles/de1202029i.htm

52. Fitzenberger, Bernd, Karsten Kohn, and Alexander C. Lembcke. 2012. "Union Density and Varieties of Coverage: The Anatoomy of Union Wage Effects in Germany." Industrial Relations, forthcoming.

53. Foster, Lucia, John Haltiwanger, and Chad Syverson. 2008. "Reallocation, Firm Turnover, and Efficiency: Selection on Productivity or Profitability?" American Economic Review 98(1): $394-425$.

54. Freeman, Richard B. 1980. "Unionism and the Dispersion of Wages." Industrial and Labor Relations Review 34(1): 3-23.

55. Freeman, Richard B. and Lawrence F. Katz. 1994. "Rising wage inequality: the United States vs. other advanced countries." in: R. Freeman, ed., Working under different rules (Russell Sage Foundation, New York).

56. French, Eric and Christopher Taber. 2011. "Identification of Models of the Labor Market." in Handbook of Labor Economics eds. Ashenfelter and Card, Vol. IV, part A, 537-617.

57. Gibbons, Robert and Lawrence F. Katz. 1992. "Does Unmeasured Ability Explain Interindustry Wage Differentials?" Review of Economic Studies 59(3): 515-535.

58. Gibbons, Robert, Lawrence F. Katz, Thomas Lemieux, and Daniel Parent 2005. "Comparative Advantage, Learning, and Sectoral Wage Determination." Journal of Labor Economics 23(4): 681-723.

59. Glitz, Albrecht. 2012. "The Labor Market Impact of Immigration: A Quasi-Experiment Exploiting Immigrant Location Rules in Germany" Journal of Labor Economics, 30(1): 175213. 
60. Goldin, Claudia and Lawrence F. Katz. 2008. The Race between Education and Technology. Cambridge: Harvard University Press.

61. Goux, Dominique and Eric Maurin. 1999. "Persistence of Interindustry Wage Differentials: A Reexamination Using Matched Worker-Firm Panel Data" Journal of Labor Economics 17(3): 492-533.

62. Groshen, Erica. 1991. "Sources of Intra-Industry Wage Dispersion: How Much Do Employers Matter?" Quarterly Journal of Economics 106(3): 869-884.

63. Gruetter, Max and Rachel Lalive. 2009. "The importance of firms in wage determination." Labour Economics 16(2): 149-160.

64. Guiso, Luigi, Luigi Pistaferri and Fabiano Schivardi. 2005. "Insurance within the Firm." Journal of Political Economy 113 (5): 1054-1087.

65. Gürtzgen, Nicole. 2007. "The effect of firm and industry-level contracts on wages - evidence from longitudinal linked employer-employee data." ZEW Discussion Paper \#06-082.

66. Gürtzgen, Nicole. 2010. "Rent-Sharing and Collective Wage Contracts - Evidence from German Establishment-Level Data." Applied Economics 42 (22): 2835- 2854.

67. Hassel, Anke. 1999. "The Erosion of the German System of Industrial Relations." British Journal of Industrial Relations 37(3): 483-505.

68. Hassel, Anke and Britta Rehder. 2001. "Institutional Change in the German Wage Bargaining System - The Role of Big Companies." MPIfG Working Paper 01/9.

69. Heinbach, Wolf Dieter. 2006. "Bargained Wages in Decentralized Wage-Setting Regimes" Institute for Applied Economic Research (IAW) Working Paper \#276.

70. Hirsch, Barry and Edward Schumacher. 2004. "Match bias in wage gap estimates due to earnings imputation." Journal of Labor Economics 22(3): 689-722.

71. Hsieh, Chang-Tai and Peter J. Klenow. 2009. "Misallocation and Manufacturing TFP in China and India." Quarterly Journal of Economics. 124(4): 1403-1448.

72. Jacobi, Lena and Jochen Kluve. 2006. "Before and After the Hartz Reforms: The Performance of Active Labour Market Policy in Germany." IZA Discussion Paper \# 2100.

73. Jung, Sven and Claus Schnabel 2009. "Paying More than Necessary? The Wage Cushion in Germany." IZA Discussion Paper \#4278. 
74. Juhn, Chinui, Kevin Murphy, and Brooks Pierce. 1993. "Wage Inequality and the Rise in Returns to Skill." Journal of Political Economy 101(3): 410-442.

75. Katz, Lawrence F. and David Autor. 1999. "Changes in the wage structure and earnings inequality." in Handbook of Labor Economics eds. Ashenfelter and Card, Vol. III, part A, 1463-1555.

76. Katz, Lawrence F., and Kevin M. Murphy. 1992. "Changes in Relative Wages, 1963-87: Supply and Demand Factors," Quarterly Journal of Economics 107(1): 35-78.

77. Katz, Lawrence F. and Lawrence Summers. 1989. "Industry Rents: Evidence and Implications." Brookings Papers on Economic Activity: Microeconomics. pp. 209-290.

78. Keane, Michael P. and Kenneth I. Wolpin. 1997. "The Career Decisions of Young Men." Journal of Political Economy 105(3): 473-522.

79. Kline, Patrick and Andres Santos. 2012. "Sensitivity to Missing Data Assumptions: Theory and An Evaluation of the U.S. Wage Structure." Quantitative Economics, forthcoming.

80. Kolhaut, Susanne und Peter Ellguth. 2008. "Neu gegründete Betriebe sind seltener tarifgebunden." IAB Kurzbericht \#16/2008.

81. Kremer, Michael and Eric Maskin. 1996. "Wage Inequality and Segregation by Skill." NBER Working paper \#5718.

82. Krueger, Alan and Lawrence Summers. 1988. "Efficiency Wages and the Inter-Industry Wage Structure." Econometrica 56(2): 259-293.

83. Kuhn, Peter and Fernando Lozano, 2008. "The Expanding Workweek? Understanding Trends in Long Work Hours Among U.S. Men, 1979-2006.” Journal of Labor Economics 26(2): 311-343.

84. Lange, Fabian. 2007. "The Speed of Employer Learning." Journal of Labor Economics 25(1): $1-35$.

85. Lee, David S. 1999. "Wage Inequality in the U.S. during the 1980s: Rising Dispersion or Falling Minimum Wage?" Quarterly Journal of Economics 114(3): 977-1023.

86. Lemieux, Thomas, Bentley Macleod, and Daniel Parent. 2009. "Performance Pay and Wage Inequality" Quarterly Journal of Economics 124(1): 1-49.

87. Lentz, Rasmus and Dale Mortensen. 2010. "Labor Market Models of Worker and Firm Heterogeneity." Annual Review of Economics 2: 577-602. 
88. Lester, Richard. 1967. "Pay Differentials by Size of Establishment." Industrial Relations 7(1): $57-67$.

89. Lopes de Melo, Rafael. 2008. "Sorting in the Labor Market: Theory and Measurement", working paper.

90. Machin, Stephen, and John Van Reenen. 1998. "Technology and Changes in Skill Structure: Evidence from Seven OECD Countries," Quarterly Journal of Economics 113(4): 1215-1244.

91. Macurdy, Thomas. 1982. "The use of time series processes to model the error structure of earnings in a longitudinal data analysis." Journal of Econometrics 18(1): 83-114.

92. Meghir, Costas and Luigi Pistaferri. 2004. "Income Variance Dynamics and Heterogeneity." Econometrica 72(1): 1-32.

93. Moretti, Enrico. 2012. "Real Wage Inequality." American Economic Journal: Applied Economics, forthcoming.

94. Murphy, Kevin M., and Robert H. Topel. 1990. "Efficiency Wages Reconsidered: Theory and Evidence." in Y. Weiss and R. Topel eds., Advances in the Theory and Measurement of Unemployment. New York: St. Martin's Press, pp. 204-40.

95. Mundlak, Yair. 1978. "On the Pooling of Time Series and Cross Section Data." Econometrica 46(1): 69-85.

96. Ochel, Wolfgang. 2003. "Decentralising Wage Bargaining in Germany - A Way to Increase Employment?" CESIfo Working Paper \#1069.

97. Postel-Vinay, Fabien and Jean-Marc Robin. 2002. "Equilibrium Wage Dispersion with Worker and Employer Heterogeneity." Econometrica 70(6): 2295-2350.

98. Rattenhuber, Pia. 2011. "Building the Minimum Wage: Germany's First Sectoral Minimum Wage and its Impact on Wages in the Construction Industry." DIW Berlin Discussion Paper \#1111. March 2011.

99. Rees, Albert and George Schultz. 1970. Workers in an urban labor market. University of Chicago Press. Chicago.

100. Reynolds, Lloyd G. 1951. The Structure of Labor Markets. New York: Harper \& Brothers.

101. Riphahn, Regina T. and Daniel D. Schnitzlein. 2011. "Wage Mobility in East and West Germany." IZA Working Paper No. 6246, December 2011. 
102. Roy, A.D. 1951. "Some Thoughts on the Distribution of Earnings." Oxford Economic Papers Oxford Economic Papers 3(2): 135-146.

103. Segal, Lewis and Daniel Sullivan. 1997. "The Growth of Temporary Services Work." Journal of Economic Perspectives 11(2): 117-136.

104. Schmieder, Johannes F. and Tanja Hethey. 2010. "Using worker flows in the analysis of establishment turnover : evidence from German administrative data." FDZ Methodenreport 06/2010, Institute for Employment Research.

105. Siebert, Horst. 1997. "Labor Market Rigidities: At the Root of Unemployment in Europe." Journal of Economic Perspectives 11(3): 37-54.

106. Skans, Oskar Nordström, Per-Anders Edin, and Bertil Holmlund. 2009. "Wage Dispersion between and within Plants: Sweden 1985-2000" in The Structure of Wages: An International Comparison eds Edward P. Lazear and Kathryn L. Shaw, University of Chicago Press.

107. Shapiro, Carl and Joseph Stiglitz. 1984. "Equilibrium Unemployment as a Worker Discipline Device." American Economic Review 74(3): 433-444.

108. Shewchuck, Jonathan Richard. 1994. "An Introduction to the Conjugate Gradient Method Without the Agonizing Pain: Edition $1 \frac{1}{4}$ " Working paper. School of Computer Science, Carnegie Mellon University.

109. Slichter, Sumner. 1950. "Notes on the Structure of Wages." Review of Economics and Statistics 32(1): 80-91.

110. Theil, Henri and Anthony Finezza. 1971. "A Note on the Measurement of Racial Integration of Schools by Means of Informational Concepts." Journal of Mathematical Sociology 1:18794.

111. Topel, Robert H and Michael P. Ward. 1992. "Job Mobility and the Careers of Young Men." The Quarterly Journal of Economics, 107(2): 439-79.

112. Van Reenan, John. 1996. "The Creation and Capture of Rents: Wages and Innovation in a Panel of U.K. Companies." Quarterly Journal of Economics 111(1): 195-226.

113. White, Halbert. 1980. "A heteroskedasticity-consistent covariance matrix and a direct test for heteroskedasticity." Econometrica 48(4): 817-838.

114. Wolff, Sascha. 2009. "Determinants of East-West-migration in Germany: A macroeconometric analysis." Working paper, Georg-August-Universität Göttingen. 
Figure 1a: Trends in Percentiles of Real Log Daily Wage

West German Men Relative to 1996 Base

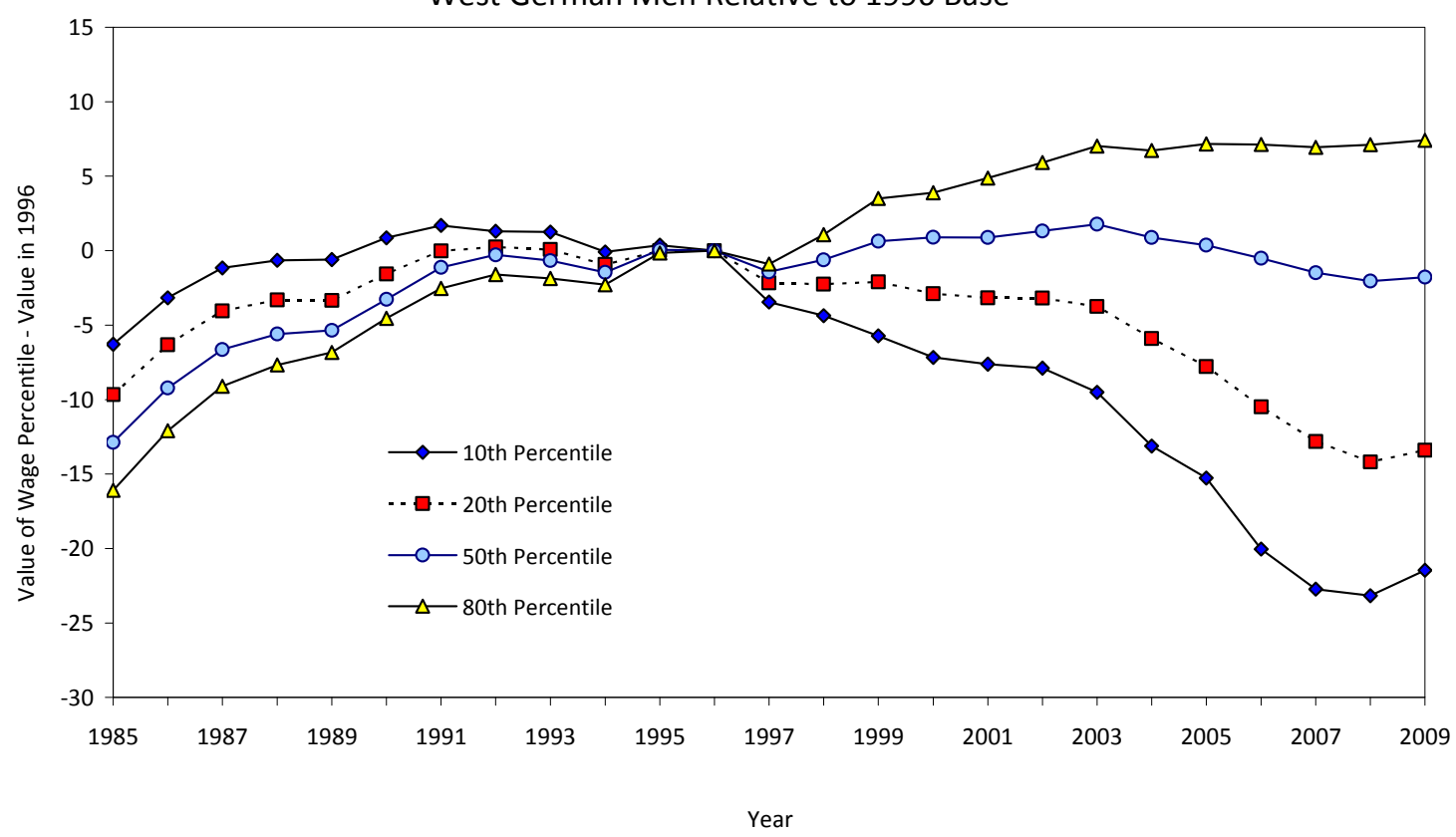

Note: figure shows percentiles of log real daily wage for full time male workers on their main job, deviated from value of same percentile in 1996 and multiplied by 100.

Figure 1b: Trends in Percentiles of Real Log Hourly Wages

U.S. Men Relative to 1979 base

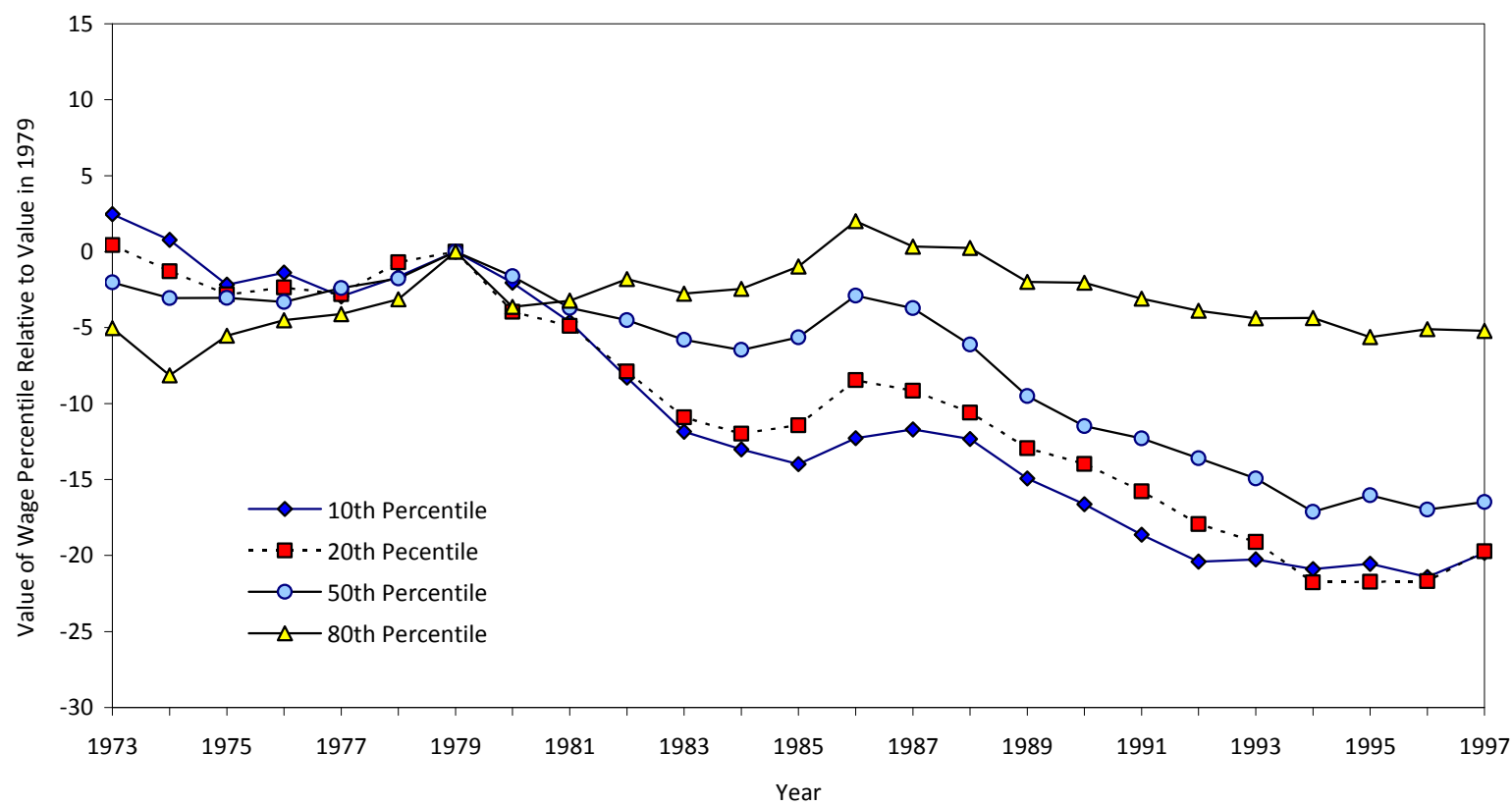

Note: figure shows percentiles of log real hourly wage for male workers, deviated from value of same percentile in 1996 and multiplied by 100. Wage data are from monthly Current Population Surveys, as tabulated in Economic Policy Institute (2009). 
Figure 2: Macroeconomic Trends and Policy Changes in Germany, 1979-2011

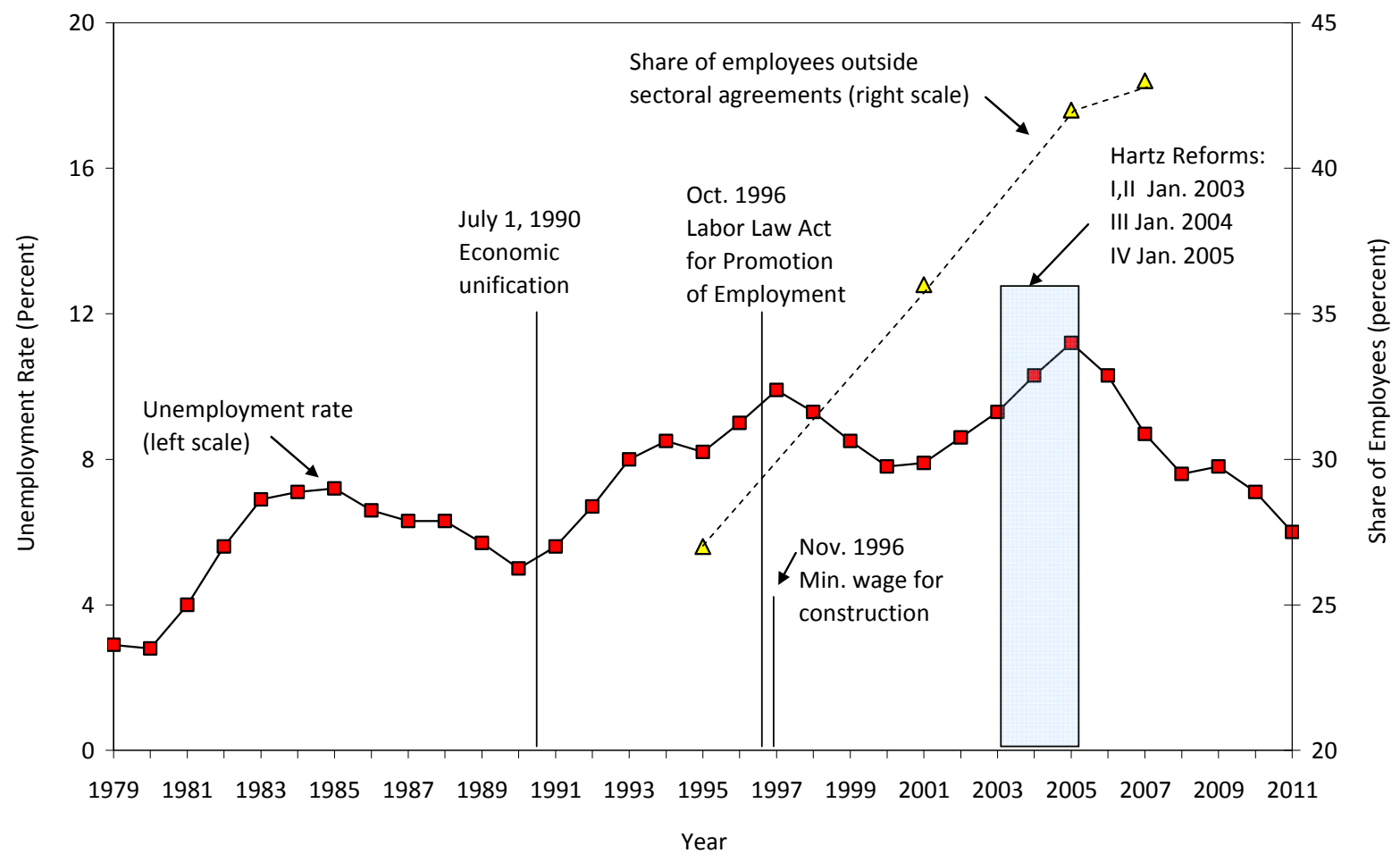


Figure 3a: Trends in Wage Inequality

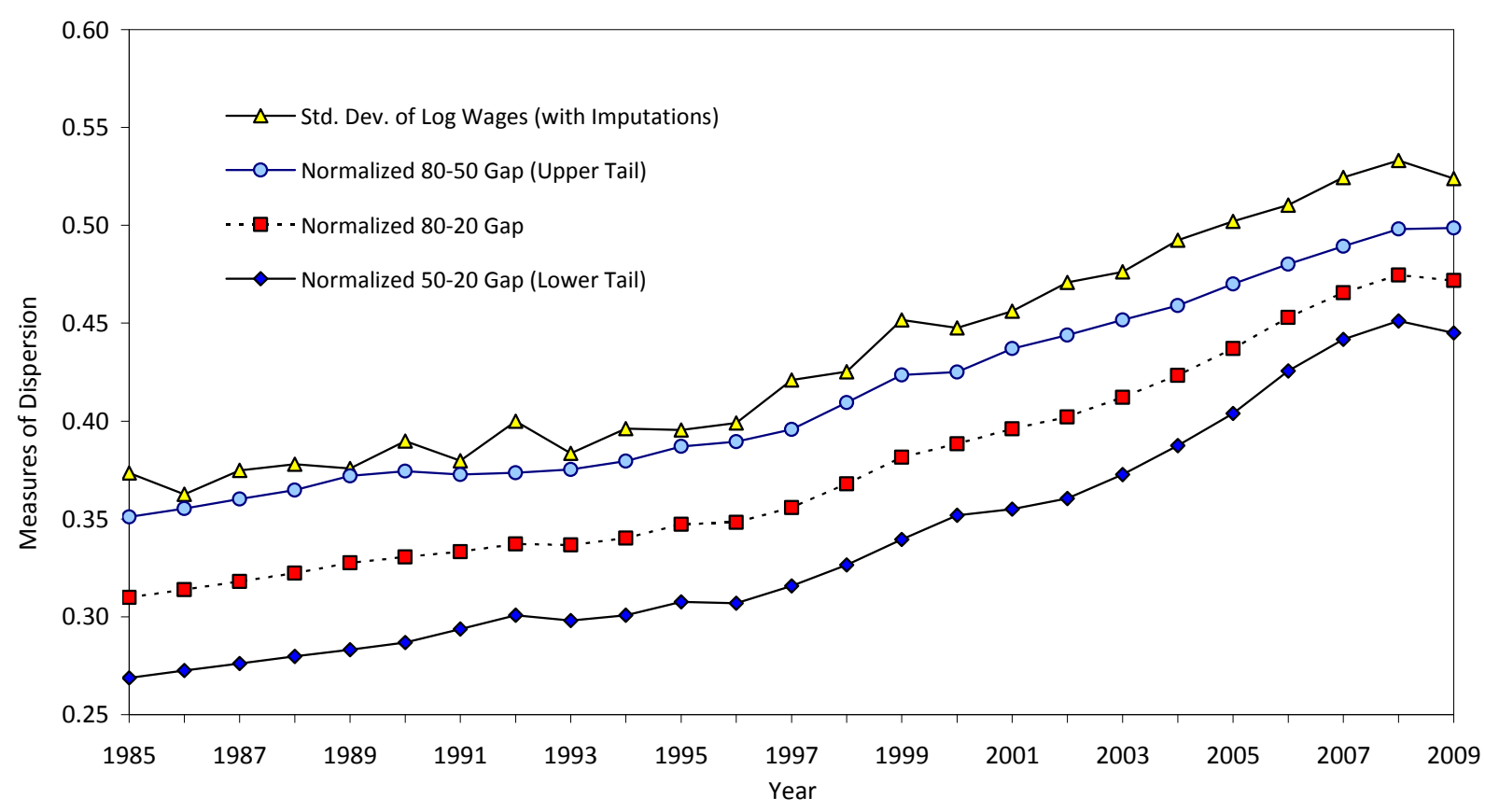

Notes: figure shows measures of dispersion in real daily wage for full time male workers. Normalized percentile gaps are differences in percentiles divided by corresponding differences in percentiles of standard normal variate.

Figure 3b: Trends in Residual Wage Inequality

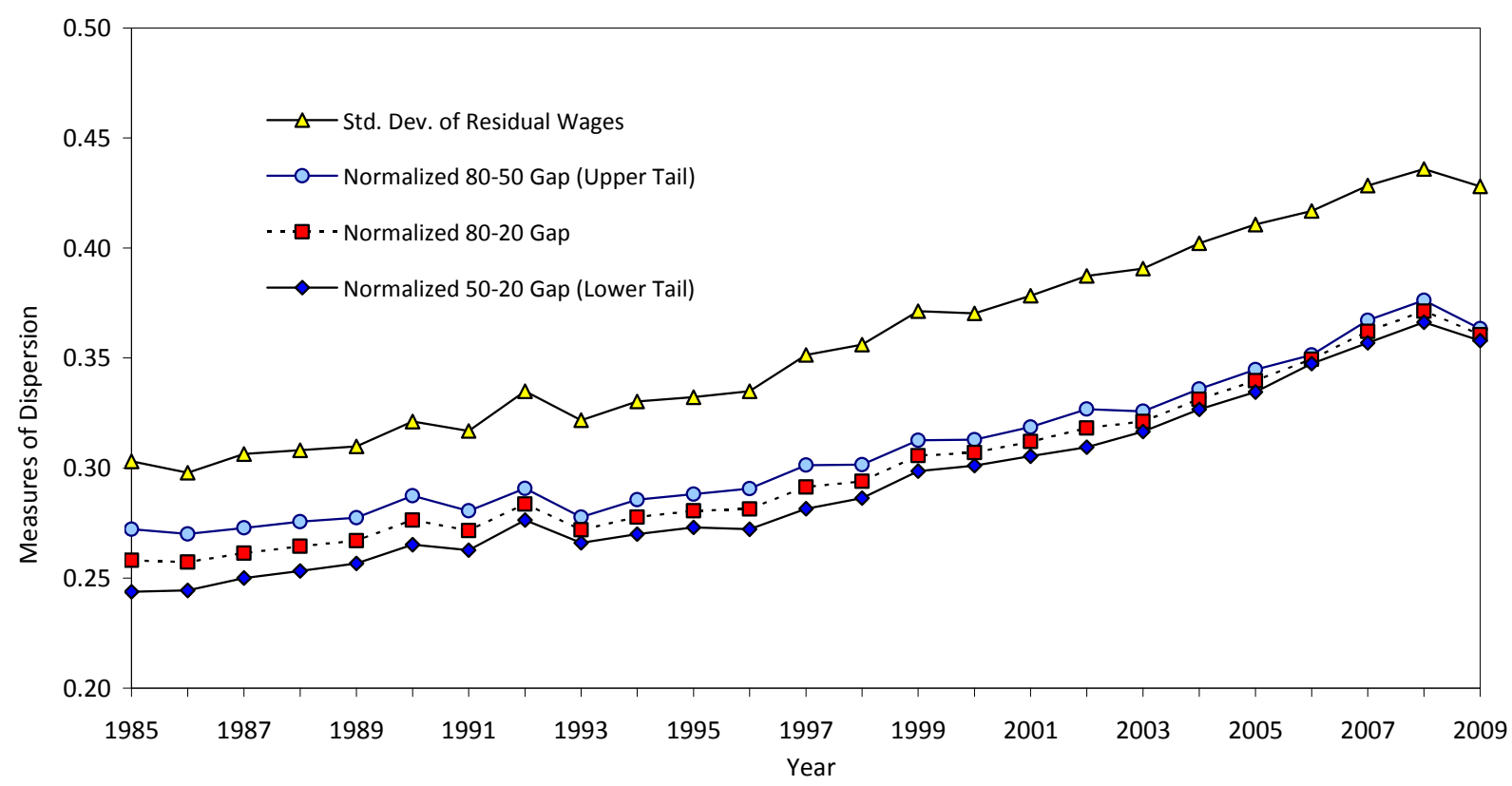

Notes: see notes to Figure 3a. Figure shows measures of dispersion in residual real daily wage for full time male workers. Residual wage is residual from linear regression model with dummies for education categories and cubic in experience fit separately in each year. 
Figure 4: Residual Standard Deviations from Alternative Wage Models

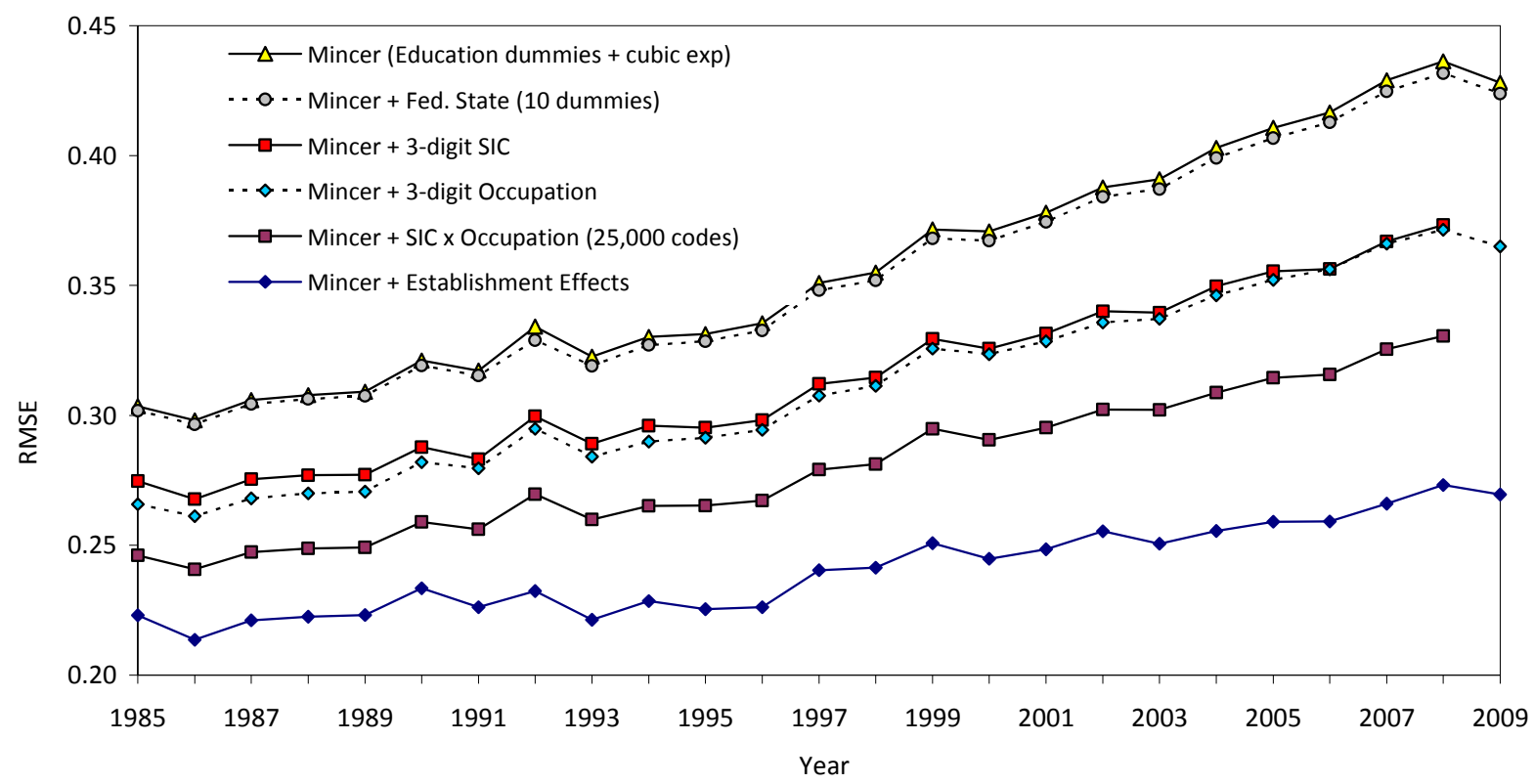

Notes: See note to Figure 3b. Figure shows measures of dispersion in residual real daily wage for full time male workers. Residual wage is residual from linear regression model. "Mincer" refers to model with dummies for education categories and cubic in experience, fit separately in each year. Other models add additional controls as indicated.

Figure 5: Sorting Across Establishments of Workers in Different Education and Occupation Groups

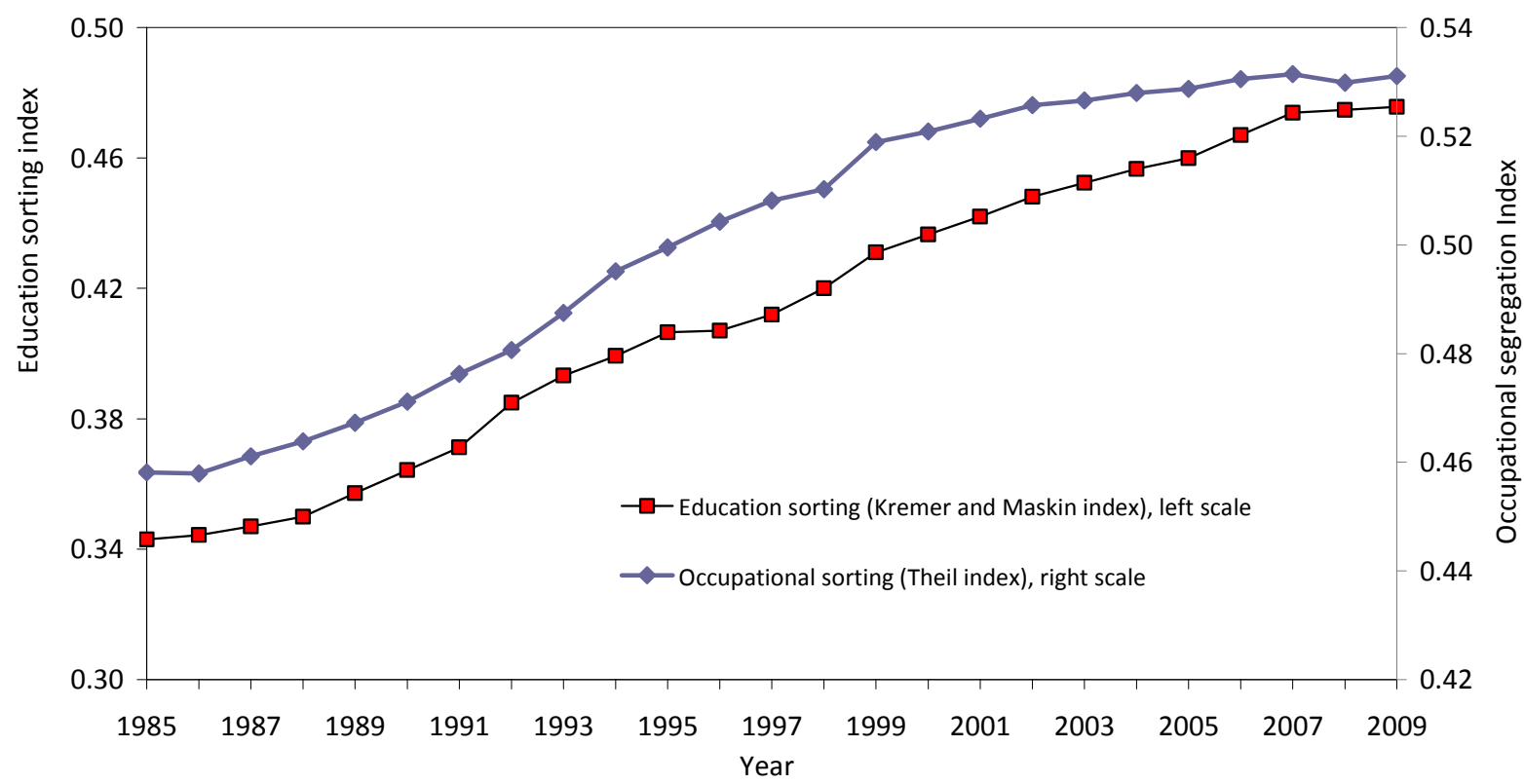

Notes: figure shows two measures of sorting of full time male workers across establishments. See text for definitions of indices. 
Figure 6a: Mean Wages of Job Changers, Classified by Quartile of Mean Wage of Co-Workers at Origin and Destination Establishment, Interval 1

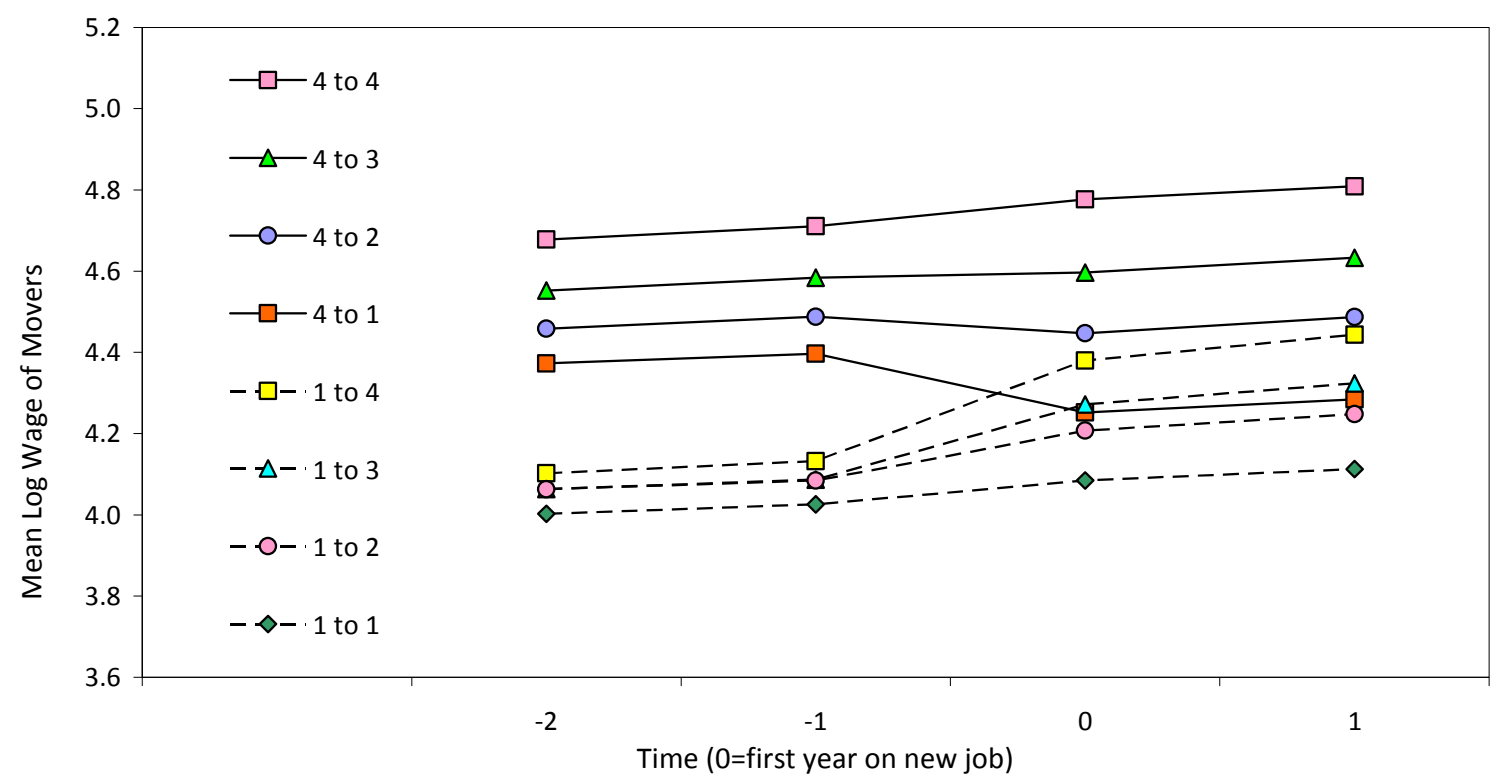

Notes: figure shows mean wages of male workers observed in 1985-1991 who change jobs in 1987, 1988 or 1989, and held the preceding job for 2 or more years, and the new job for 2 or more years. "Job" refers to establishment with most earnings in year, excluding part time work. Each job is classified into quartiles based on mean wage of co-workers (quartiles are based on all full time workers in the same year).

Figure 6b: Mean Wages of Job Changers, Classified by Quartile of Mean Wage of Co-Workers at Origin and Destination Establishment, Interval 4

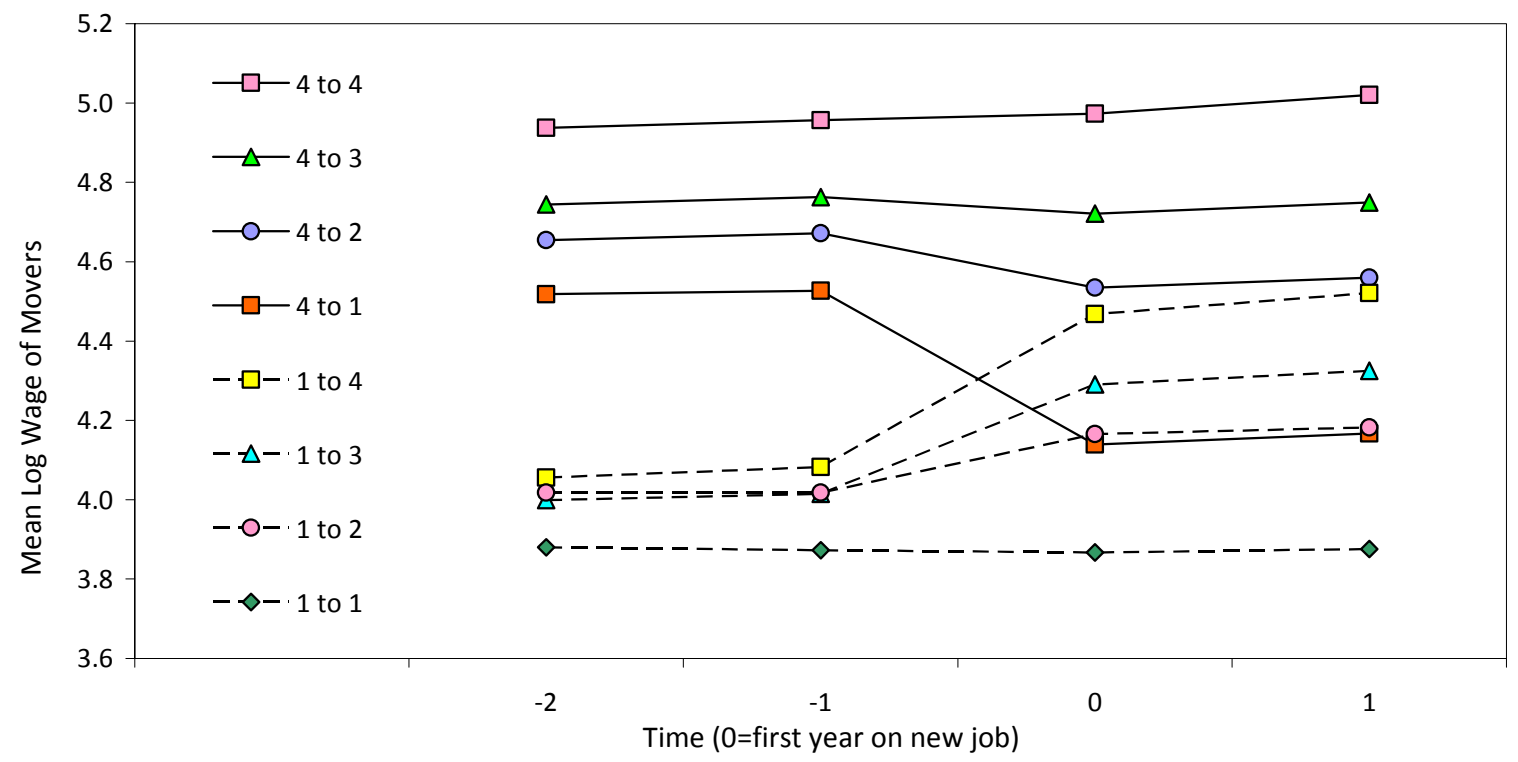

Notes: figure shows mean wages of male workers observed in 2002-2009 who change jobs in 2004-2007 and held the preceding job for 2 or more years, and the new job for 2 or more years. "Job" refers to establishment with most earnings in year, excluding part time work. Each job is classified into quartiles based on mean wage of co-workers (quartiles are based on all full time workers in the same year). 
Figure 7: Relative Explanatory Power of AKM Model in Different Periods

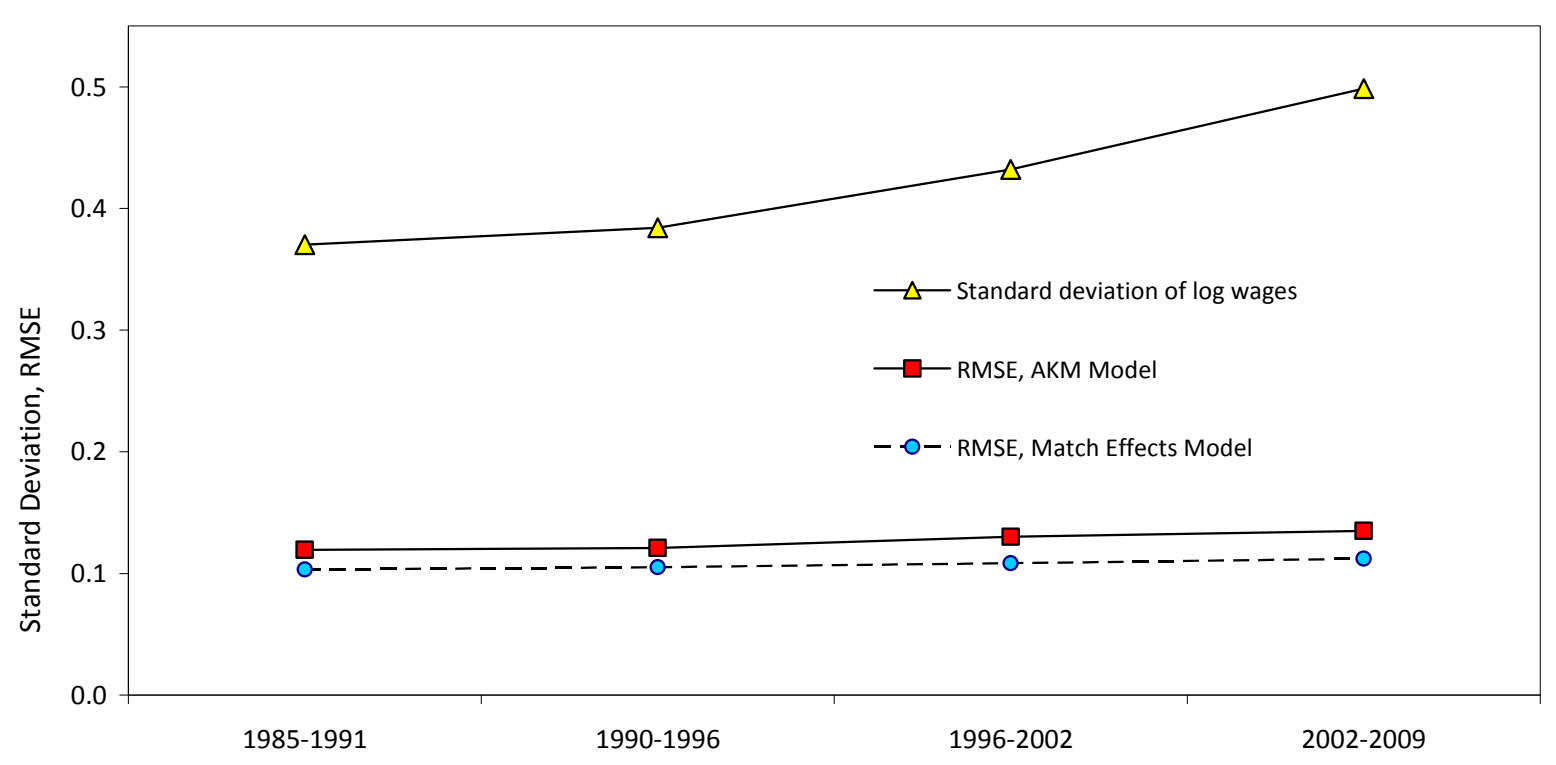

Notes: figure shows standard deviation of log real wages for full time male workers in indicated interval, along with root-mean-squared error (RMSE) from AKM specification and alternative model with unrestricted match effects. See notes to Table 3 for description of models. 


\section{Figure 8a: Mean Residual by Person/Establishment Deciles, Interval 1}

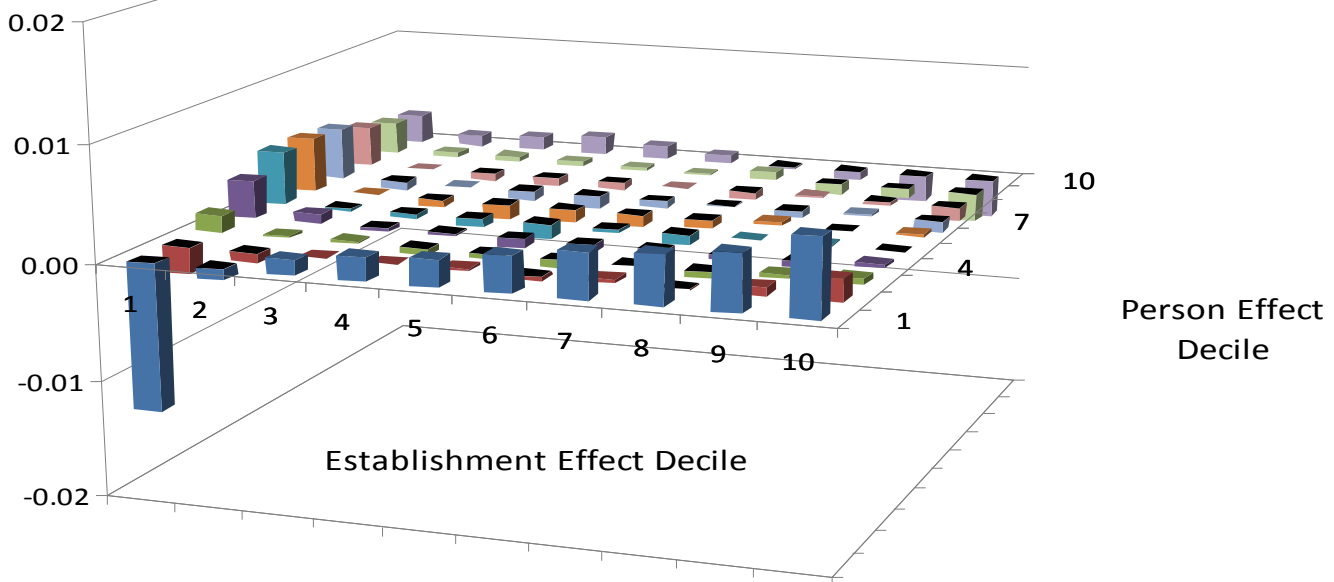

Notes: figure shows mean residuals from estimated AKM model with cells defined by decile of estimated establishment effect, interacted with decile of estimated person effect. See Table 3 for summary of model parameters.

\section{Figure 8b: Mean Residual by Person/Establishment Deciles, Interval 4}

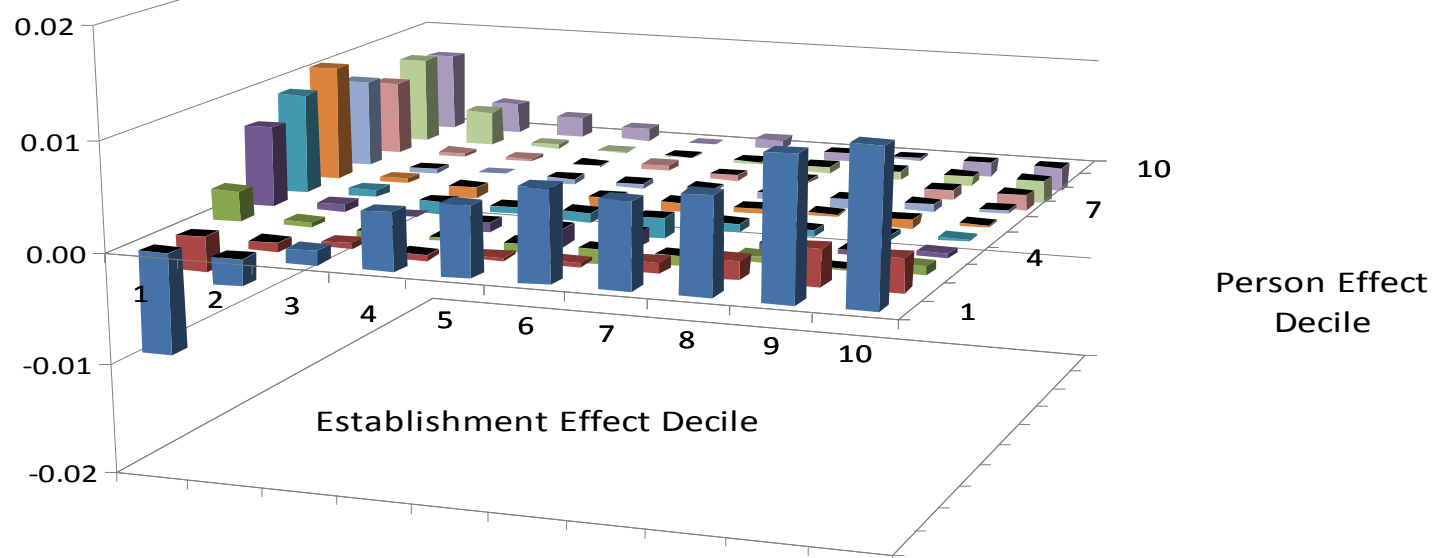

Notes: figure shows mean residuals from estimated AKM model with cells defined by decile of estimated establishment effect, interacted with decile of estimated person effect. See Table 3 for summary of model parameters. 
Figure 9a: Mean Wages of Movers, Classified by Quartile of Establishment Effects for Origin and Destination Firms, Interval 4

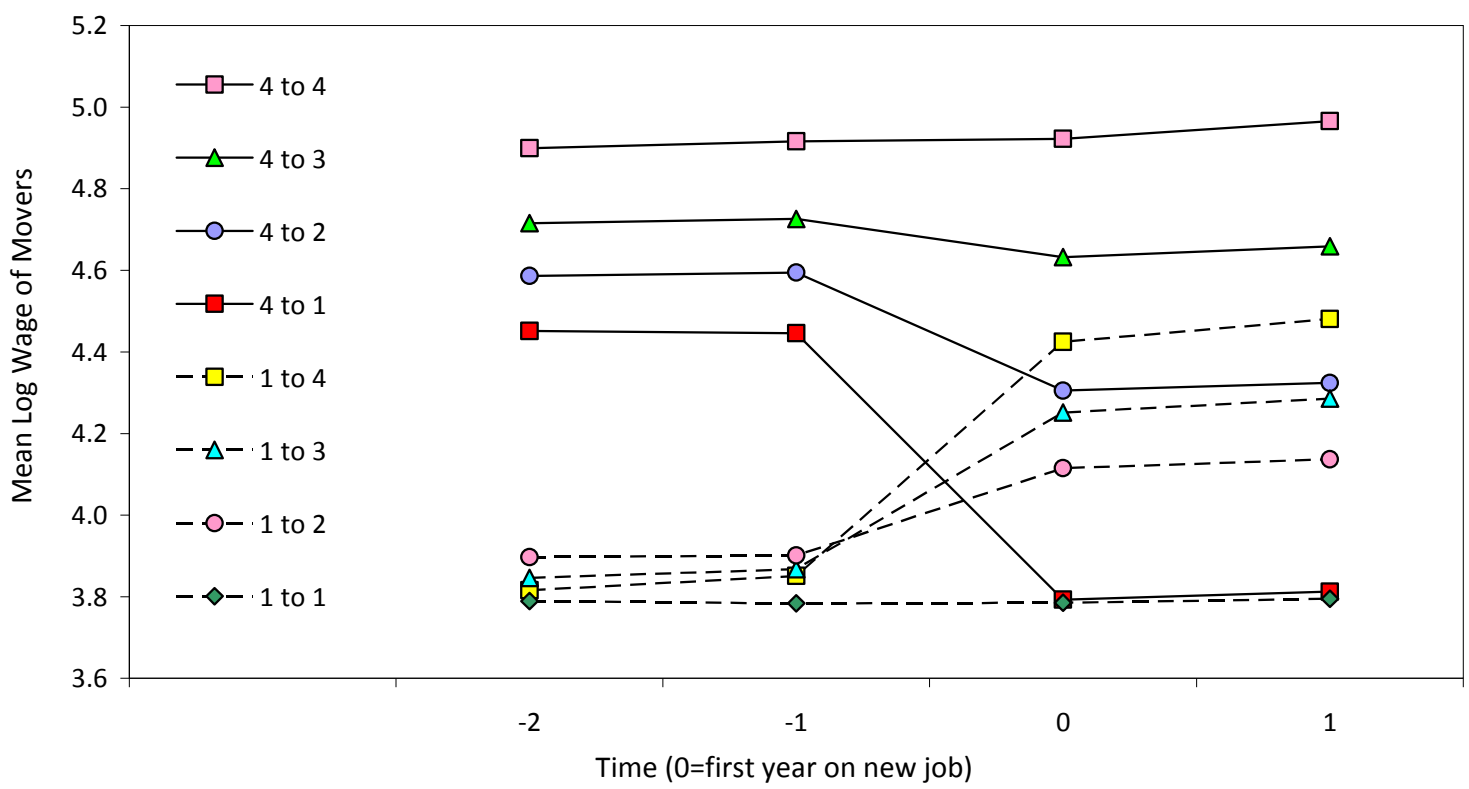

Notes: figure shows mean wages of male workers observed in 2002-2009 who change jobs in 2004-2007, and held the preceding job for 2 or more years, and the new job for 2 or more years. "Job" refers to main job in year, excluding part time jobs. Each job is classified into quartiles based on estimated establishment effect from AKM model presented in Table 3.

Figure 9b: Mean AKM Residuals of Movers, Classified by Quartile of Establishment Effects for Origin and Destination Firm, Interval 4

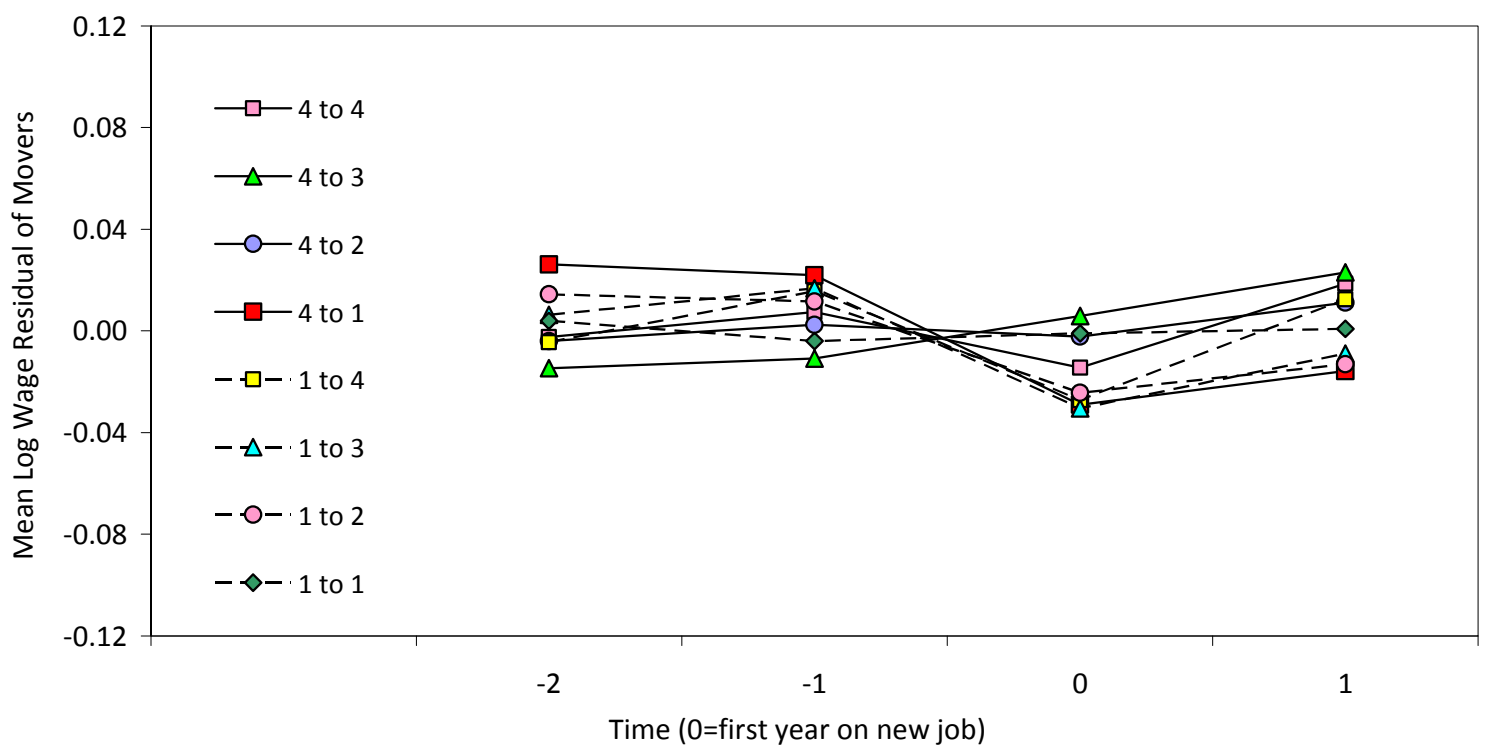

Notes: figure shows mean wage residuals from estimated AKM model for male workers observed in 2002-2009 who change jobs in 2004-2007, and held the preceding job for 2 or more years, and the new job for 2 or more years. "Job" refers to main job in year, excluding part time jobs. Each job is classified into quartiles based on estimated establishment effect from AKM model presented in Table 3. 


\section{Figure 10a: Joint Distribution of Person and Establishment Effects, Interval 1}

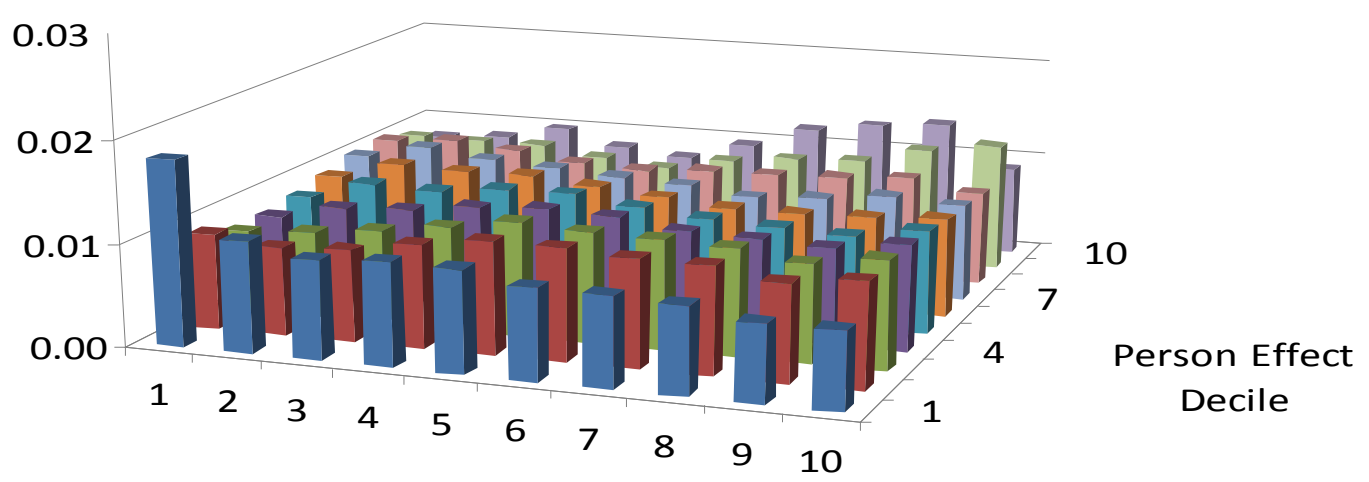

Establishment Effect Decile

Note: figure shows joint distribution of estimated person and establishment effects from AKM model. See Table 3 for summary of model parameters.

\section{Figure 10b: Joint Distribution of Person and Establishment Effects, Interval 4}

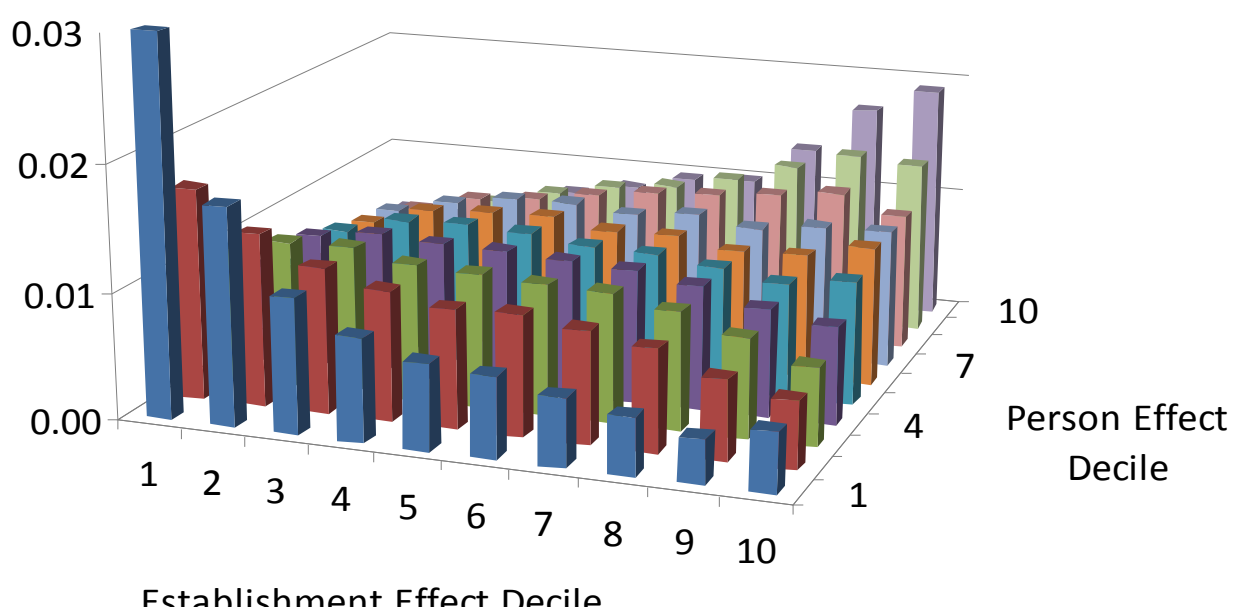

Note: figure shows joint distribution of estimated person and establishment effects from AKM model. See Table 3 for summary of model parameters. 
Figure 11: Decomposition of Variance of Log Wages

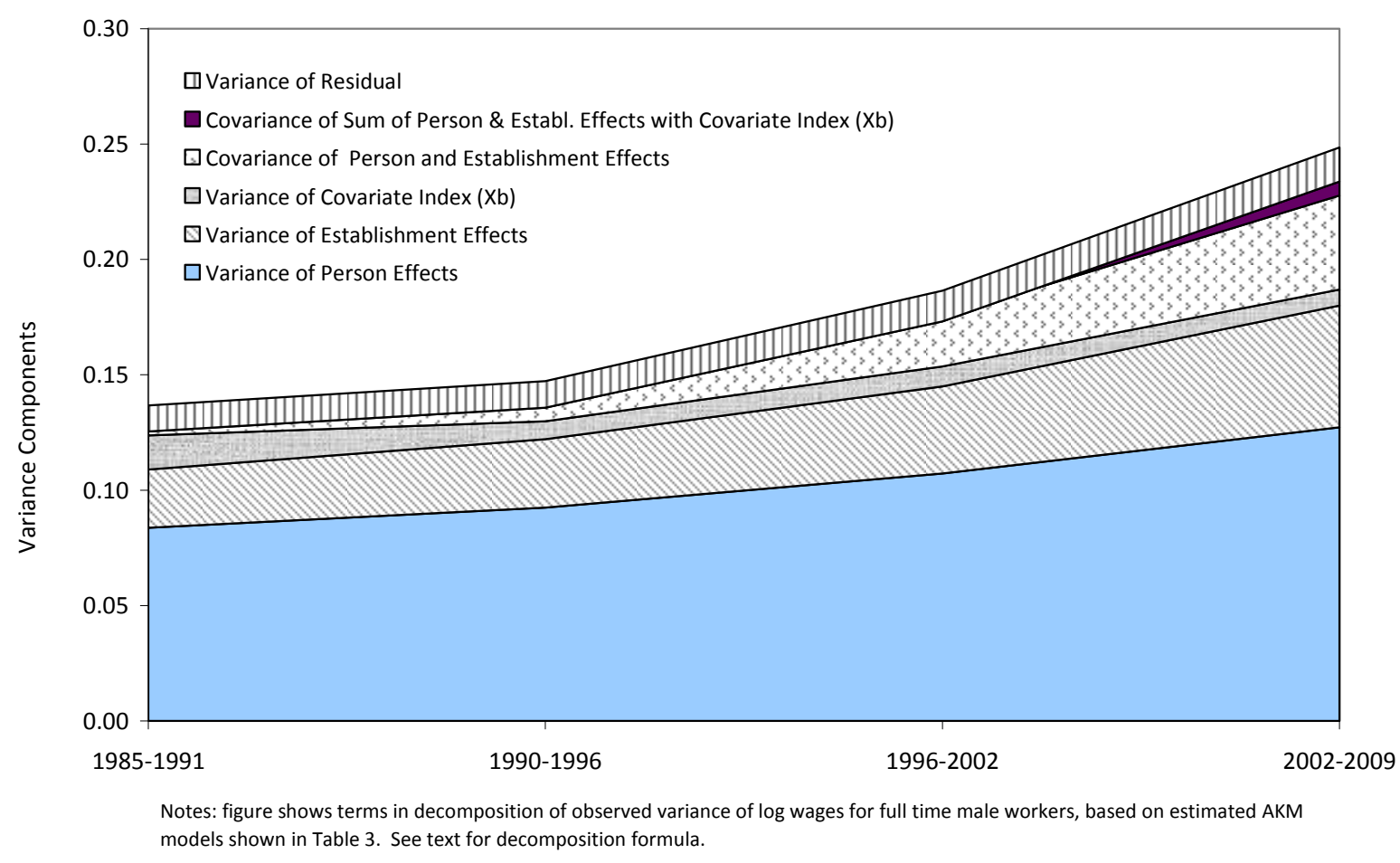


Figure 12: Assignment of Workers to Establishments by Education Group: 1985-91 vs. 2002-09

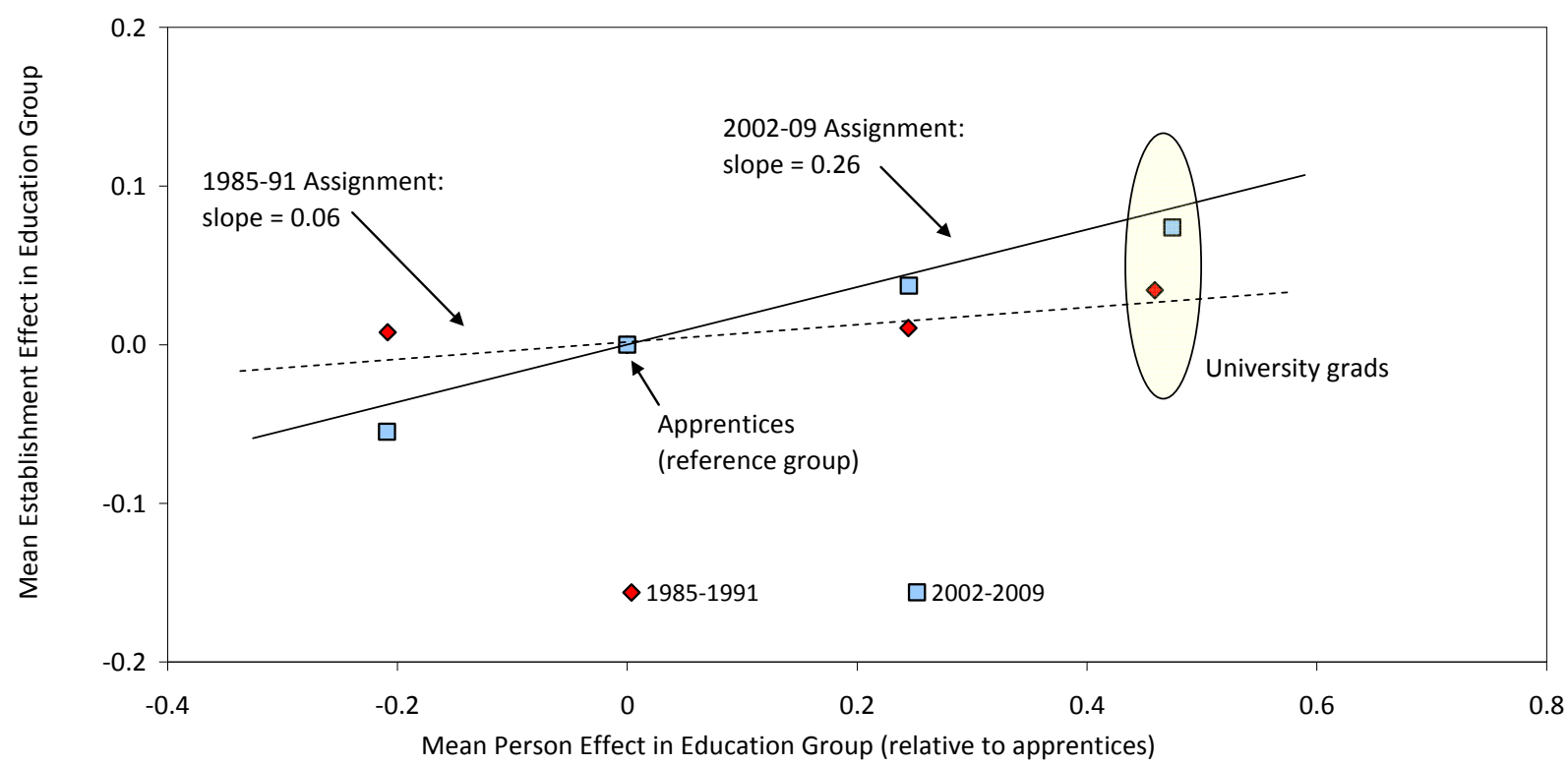

Notes: figure plots estimated mean establishment effects in 1985-1991 (red diamonds) or 2002-2009 (blue squares) for each of 4 major education groups against corresponding estimates of mean person effects in same years. Mean person and establishment effects for each time interval are deviated from mean for "apprentice" education group. Dashed line shows OLS regression of mean establishment effects against mean person effects in 1985-1991. Solid line shows similar regression in 2002-2009. See Table 4 for list of education groups. Note that "missing or none" education group is not included in this Figure.

Figure 13: Mundlak Decomposition of Return to Education

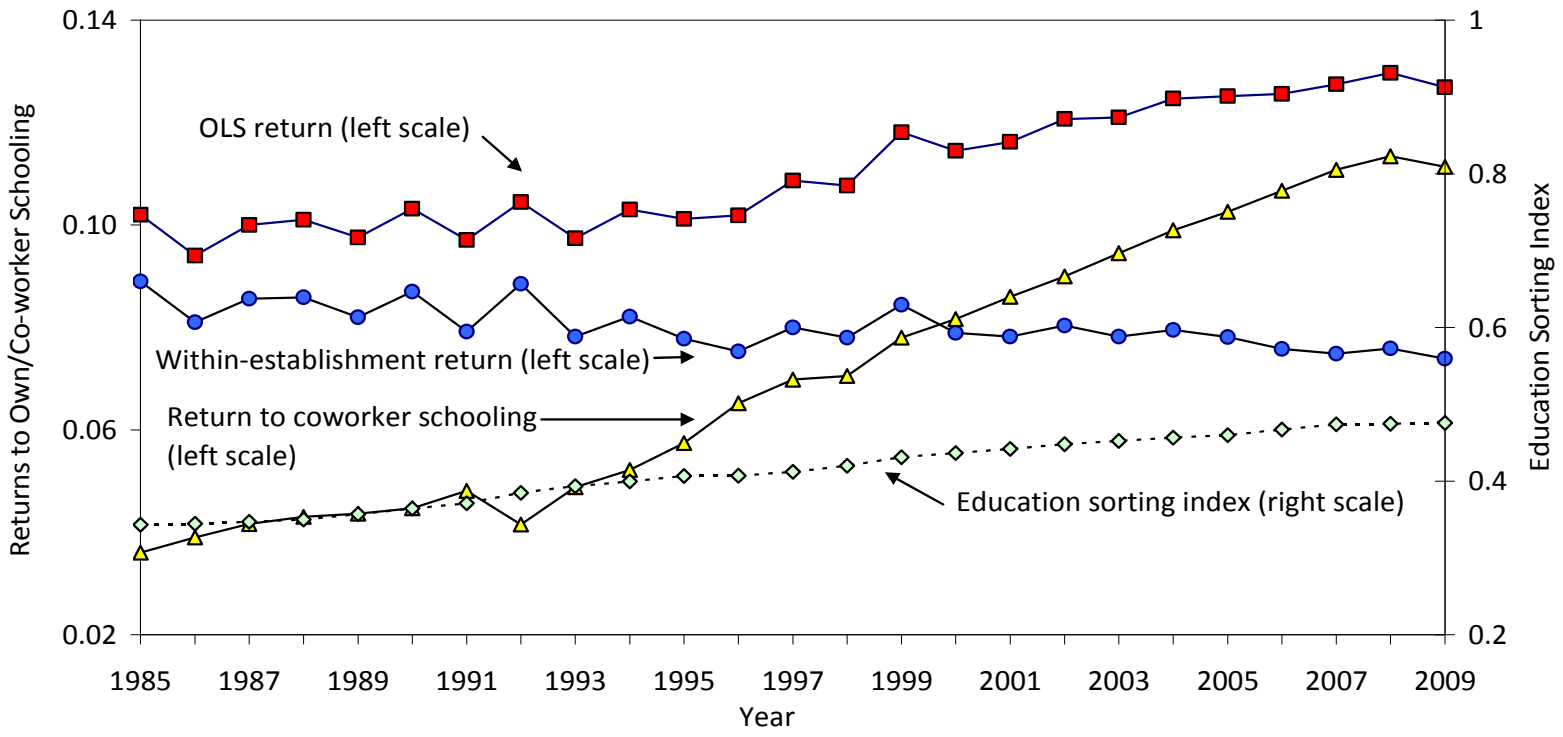

Note: figure shows components of decomposition of conventional (OLS) return to education in each year. The OLS return (plotted with red squares) is the sum of the within-establishment return (plotted with blue circles) and the product of the return to co-worker schooling (plotted with yellow triangles) and the education sorting index (plotted with pale green diamonds). See text for formula, first derived by Mundlak (1978). OLS return is coefficient on years of schooling in regression model for log real daily wages that also controls for cubic in experience. 
Figure 14a: Between-Occupation Wage Inequality: 2002-09 vs. 1985-91

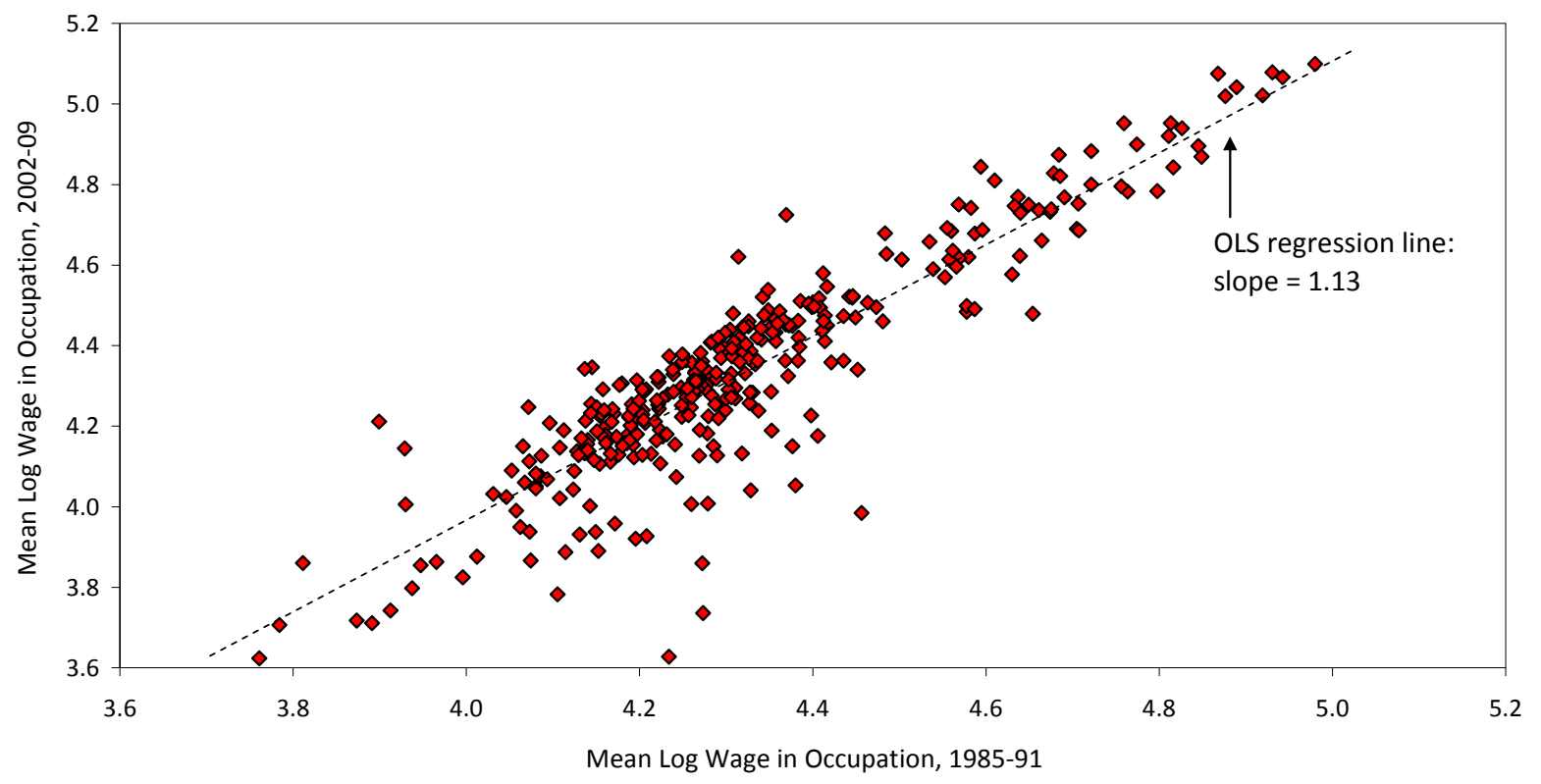

Notes: figure plots mean log real wages of full time male workers in an occupation in 2002-2009 against corresponding mean in 1985-1991. There are 342 3-digit occupations shown. Dashed line is OLS regression fit.

Figure 14b: Rising Correlation Between Mean Worker and Establishment Effects Across Occupations

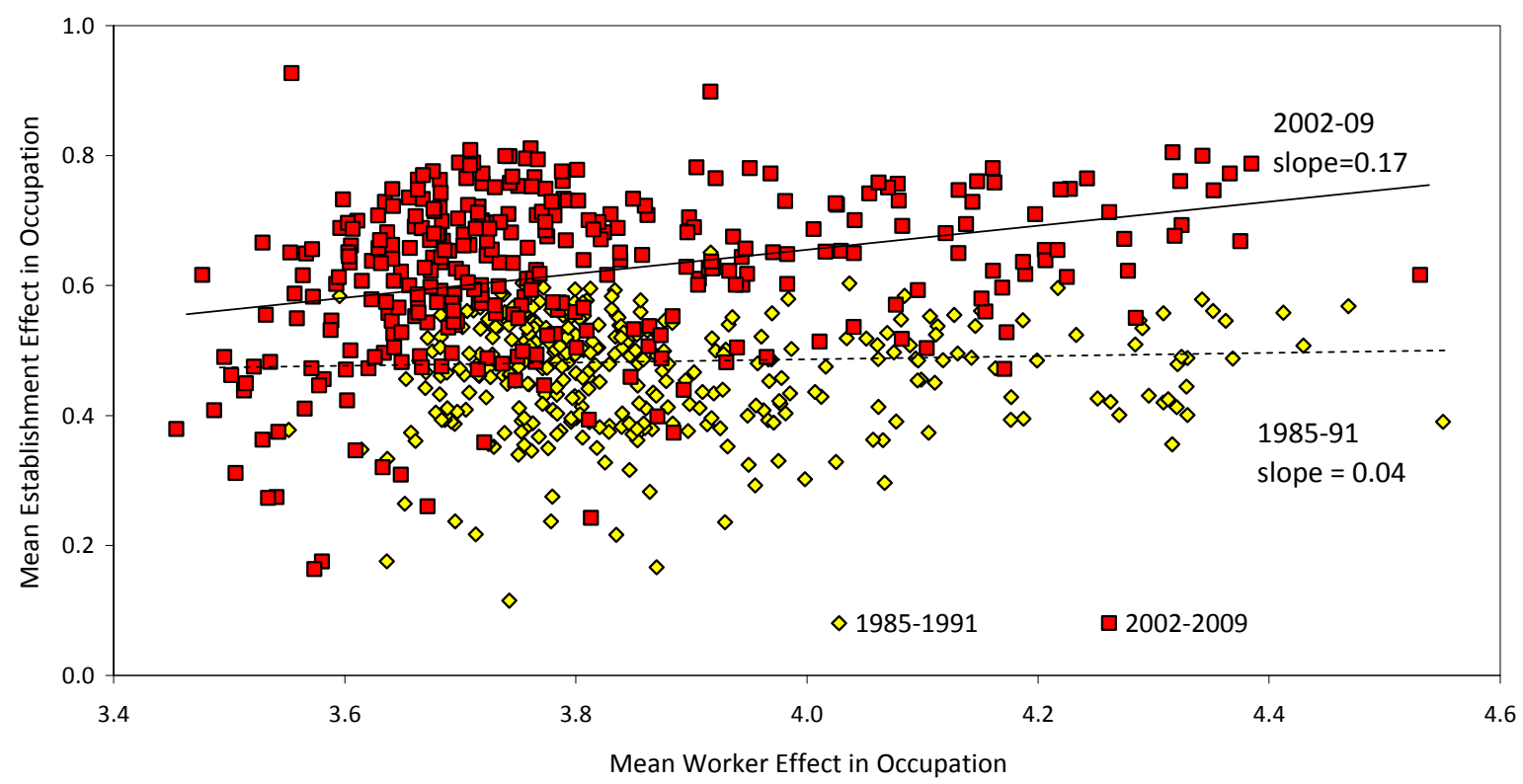

Note: figure plots estimated mean establishment effect in each of 342 occupations in 1985-1991 (yellow diamonds) or 2002-2009 (red squares) against corresponding estimated mean person effect in each occupation. Solid line shows estimated OLS regression relating the mean establishment effect in each occupation in 2002-2009 to the corresponding mean person effect. Dashed line shows corresponding OLS regression for 1985-1991 data. 
Figure 15: Standard Deviation of Establishment Effects and Fraction Covered by Collective Agreements, by Birth Year of Establishment

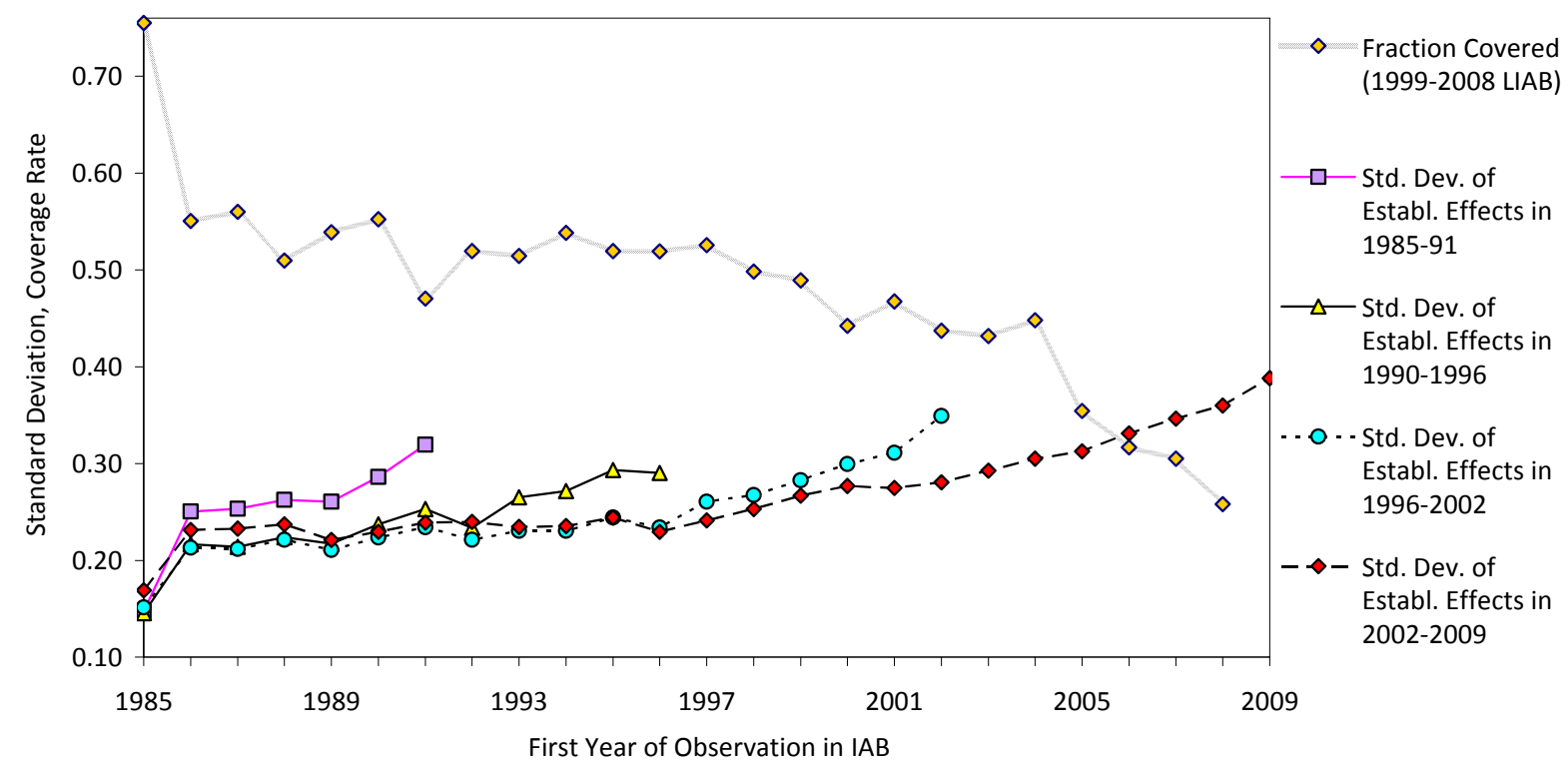

Notes: figure shows standard deviation of estimated establishment effects in a given observation interval (1985- 1991, 1990-1996, 1996-2002, or 2002-2009) for establishments that are present in that interval and first appeared with positive full time male employment in the IEB data in the "birth year" indicated on the $x$-axis. Figure also shows fraction of establishments in a given birth year surveyed in the 1999-2008 LIAB that are covered by collective agreements.

Figure 16: Distribution of Establishment Effects by Collective Bargaining Status (Based on Establishment Effects for 1996-2002, Bargaining Status in 2000 LIAB)

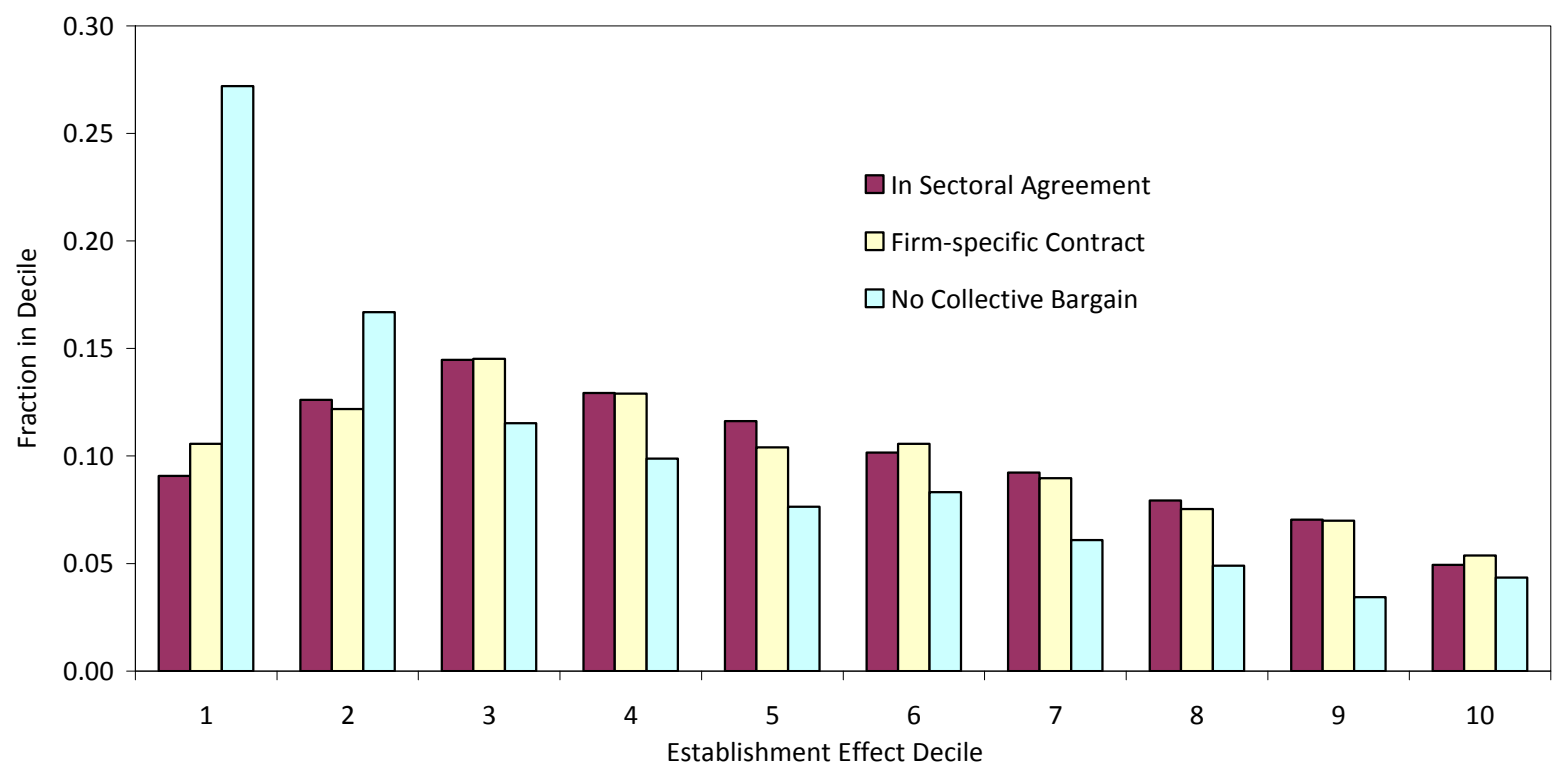

Note: figure shows distribution of collective bargaining coverage status (no collective bargain, covered by firm-specific agreement, or covered by sectoral agreement) for 7,080 establishments in 2000 Wave of LIAB that can be linked to IEB data, and for which estimated establishment effect from AKM model fit to 2002-2009 IEB data is in decile shown on x-axis. 
Figure 17a: Survivor Functions for Establishments First Observed in 1989

By Quartile of Estimated Establishment Effect

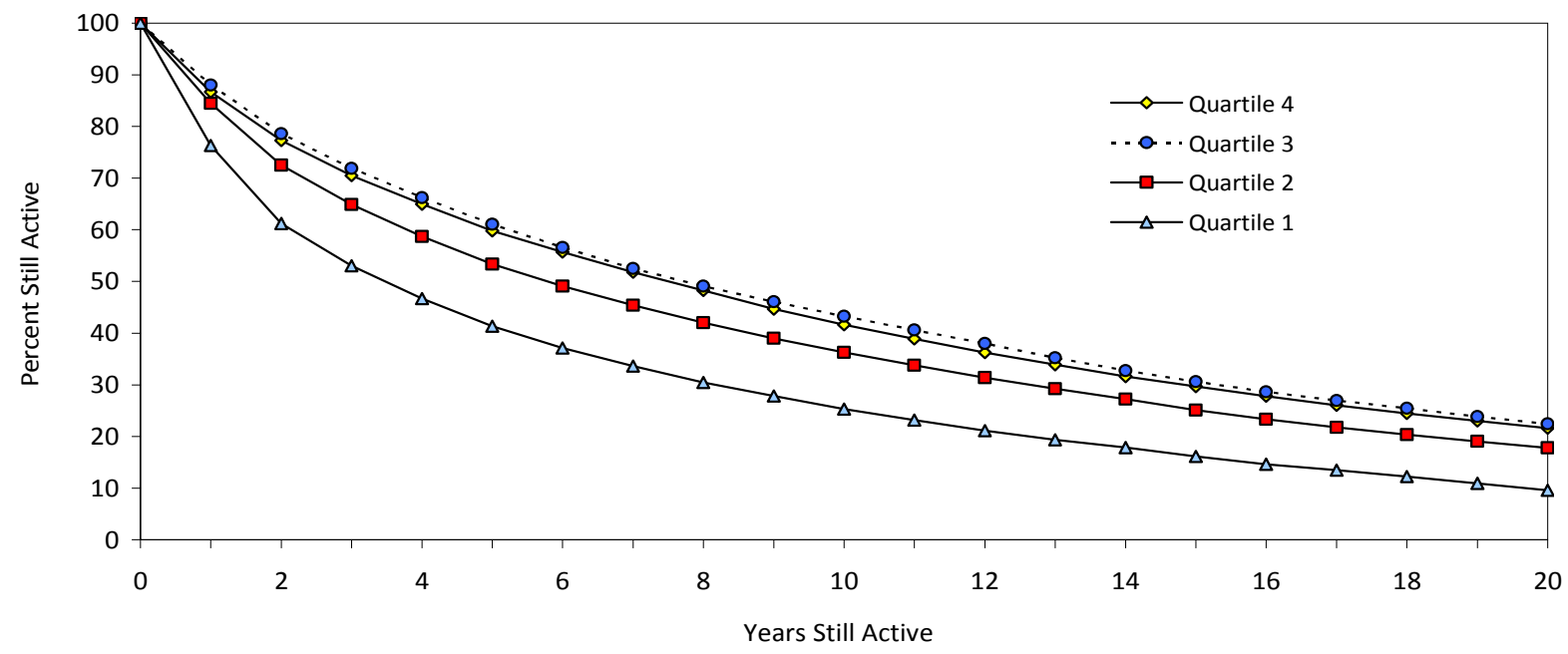

Notes: figure shows fraction of establishments that first appear in IEB data with positive full time male employment in 1989 that are still present after number of years indicated by $\mathrm{x}$-axis. Establishments are divided into quartiles based on their estimated establishment effects from an AKM model fit to data from 1985 to 1991 . Quartile 1 refers to the lowest quartile of estimated establishment effects.

Figure 17b: Survivor Functions for Jobs Initiated in 1989

By Quartile of Estimated Establishment Effect

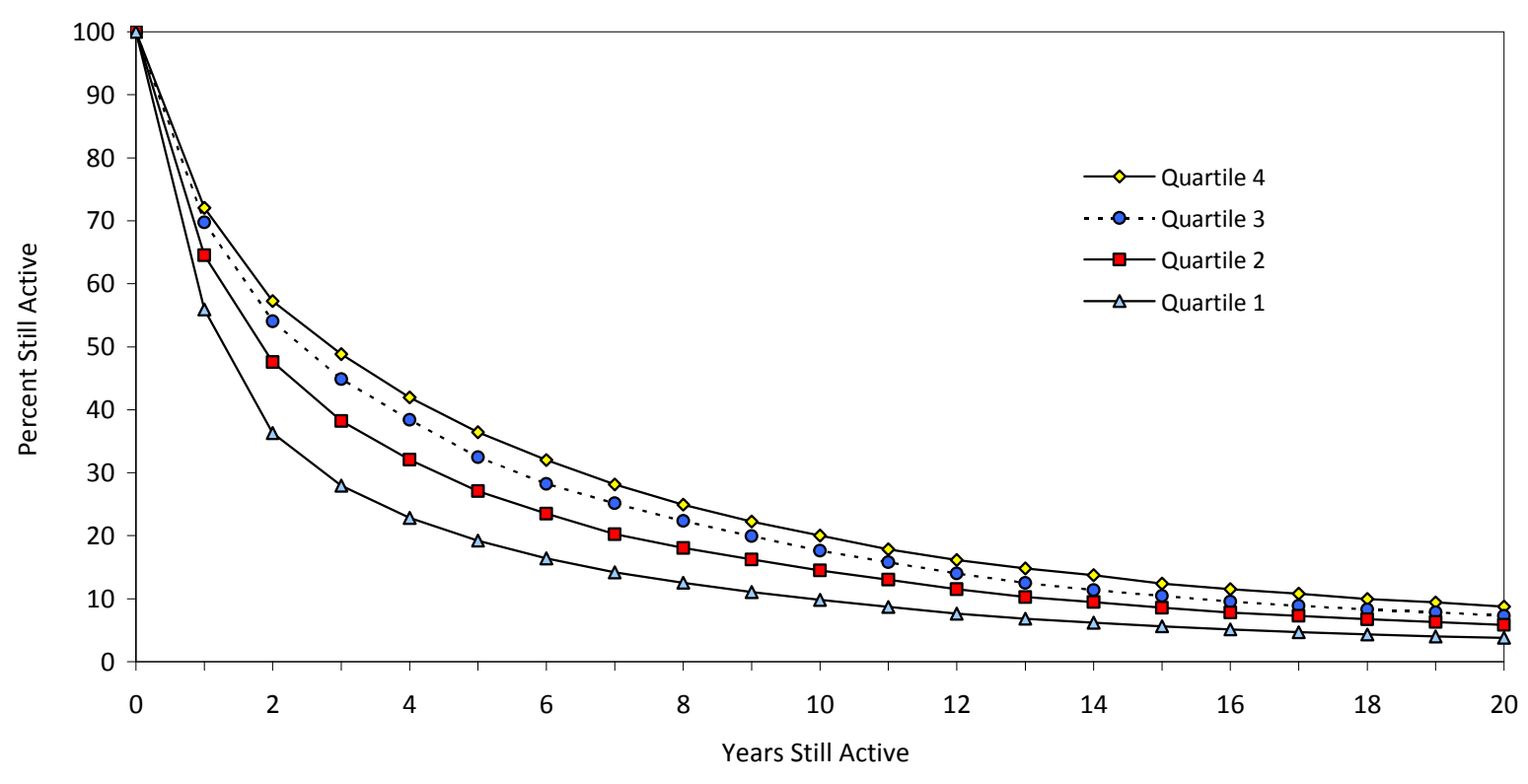

Notes: figure shows fraction of jobs held by full time male workers in IEB that were initiated in 1989 and are still present after number of years indicated by $x$-axis. Establishments are divided into quartiles based on their estimated establishment effects from an AKM model fit to data from 1985 to 1991. Quartile 1 refers to the lowest quartile of estimated establishment effects. 
Table 1: Summary Statistics for Overall Sample and Individuals in Largest Connected Set

\begin{tabular}{|c|c|c|c|c|c|c|c|c|}
\hline \multirow[b]{3}{*}{ Interval } & \multicolumn{4}{|c|}{ All full time men, age $20-60$} & \multicolumn{4}{|c|}{ Individuals in Largest Connected Set } \\
\hline & \multirow{2}{*}{$\begin{array}{c}\text { Number } \\
\text { person/yr. obs. } \\
\text { (1) }\end{array}$} & \multirow{2}{*}{$\begin{array}{c}\text { Number } \\
\text { Individuals } \\
\text { (2) }\end{array}$} & \multicolumn{2}{|c|}{ Log Real Daily Wage } & \multirow{2}{*}{$\begin{array}{c}\text { Number } \\
\text { person/yr. obs. } \\
\text { (5) }\end{array}$} & \multirow{2}{*}{$\begin{array}{c}\text { Number } \\
\text { Individuals } \\
(6) \\
\end{array}$} & \multicolumn{2}{|c|}{ Log Real Daily Wage } \\
\hline & & & $\begin{array}{c}\text { Mean } \\
\text { (3) }\end{array}$ & $\begin{array}{l}\text { Std. Dev. } \\
\text { (4) }\end{array}$ & & & $\begin{array}{c}\text { Mean } \\
(7) \\
\end{array}$ & $\begin{array}{c}\text { Std. Dev. } \\
(8)\end{array}$ \\
\hline 1985-1991 & $86,230,097$ & $17,021,779$ & 4.344 & 0.379 & $84,185,730$ & $16,295,106$ & 4.351 & 0.370 \\
\hline largest connected/all & & & & & 97.6 & 95.7 & 100.2 & 97.7 \\
\hline $1990-1996$ & $90,742,309$ & $17,885,361$ & 4.391 & 0.392 & $88,662,398$ & $17,223,290$ & 4.398 & 0.384 \\
\hline largest connected/all & & & & & 97.7 & 96.3 & 100.2 & 97.9 \\
\hline $1996-2002$ & $85,853,626$ & $17,094,254$ & 4.397 & 0.439 & $83,699,582$ & $16,384,815$ & 4.405 & 0.432 \\
\hline largest connected/all & & & & & 97.5 & 95.8 & 100.2 & 98.3 \\
\hline $2002-2009$ & $93,037,963$ & $16,553,835$ & 4.387 & 0.505 & $90,615,841$ & $15,834,602$ & 4.397 & 0.499 \\
\hline largest connected/all & & & & & 97.4 & 95.7 & 100.2 & 98.8 \\
\hline $\begin{array}{l}\text { Change from first } \\
\text { to last interval }\end{array}$ & & & 0.043 & 0.126 & & & 0.045 & 0.128 \\
\hline
\end{tabular}

Notes: Sample consists of full-time male workers ages 20-60 employed in non-marginal jobs and not currently in training. Daily wage is imputed for censored observations (see Appendix for details). "Connected set" refers to group of firms connected by worker mobility over the sample interval (for details, see Abowd, Creecy, and Kramarz, 2002). 
Table 2: Estimation Results for AKM Model, Fit by Interval

\begin{tabular}{|c|c|c|c|c|}
\hline & $\begin{array}{l}\text { Interval } 1 \\
\text { 1985-1991 } \\
\quad(1)\end{array}$ & $\begin{array}{c}\text { Interval } 2 \\
1990-1996 \\
(2)\end{array}$ & $\begin{array}{c}\text { Interval } 3 \\
1996-2002 \\
(3)\end{array}$ & $\begin{array}{l}\text { Interval } 4 \\
2002-2009 \\
(4)\end{array}$ \\
\hline \multicolumn{5}{|l|}{ Person and Establishment Parameters: } \\
\hline Number person effects & $16,295,106$ & $17,223,290$ & $16,384,815$ & $15,834,602$ \\
\hline Number establishment effects & $1,221,098$ & $1,357,824$ & $1,476,705$ & $1,504,095$ \\
\hline \multicolumn{5}{|l|}{ Summary of Parameter Estimates: } \\
\hline Std. dev. of person effects & 0.289 & 0.304 & 0.327 & 0.357 \\
\hline Std. dev. of establ. effects & 0.159 & 0.172 & 0.194 & 0.230 \\
\hline Std. dev. of Xb & 0.121 & 0.088 & 0.093 & 0.084 \\
\hline $\begin{array}{l}\text { Correlation of person/establ. effects } \\
\text { (across person-year obs.) }\end{array}$ & 0.034 & 0.097 & 0.169 & 0.249 \\
\hline $\begin{array}{l}\text { Correlation of person effects/Xb } \\
\text { (across person-year obs.) }\end{array}$ & -0.051 & -0.102 & -0.063 & 0.029 \\
\hline $\begin{array}{l}\text { Correlation of establ. effects/Xb } \\
\text { (across person-year obs.) }\end{array}$ & 0.057 & 0.039 & 0.050 & 0.112 \\
\hline RMSE of AKM residual & 0.119 & 0.121 & 0.130 & 0.135 \\
\hline Adjusted R-squared & 0.896 & 0.901 & 0.909 & 0.927 \\
\hline \multicolumn{5}{|l|}{ Comparison Match Model } \\
\hline RMSE of Match model & 0.103 & 0.105 & 0.108 & 0.112 \\
\hline Adjusted R-squared & 0.922 & 0.925 & 0.937 & 0.949 \\
\hline Std. Dev. of Match Effect* & 0.060 & 0.060 & 0.072 & 0.075 \\
\hline \multicolumn{5}{|l|}{ Addendum } \\
\hline Std. Dev. Log Wages & 0.370 & 0.384 & 0.432 & 0.499 \\
\hline Sample size & $84,185,730$ & $88,662,398$ & $83,699,582$ & $90,615,841$ \\
\hline \multicolumn{5}{|c|}{$\begin{array}{l}\text { Notes: Results from OLS estimation of equation (1) in text, see computational appendix for details. See notes to } \\
\text { Table } 1 \text { for sample composition. Xb includes year dummies interacted with education dummies, and quadratic and } \\
\text { cubic terms in age interacted with education dummies (total of } 39 \text { parameters in intervals 1-3, } 44 \text { in interval 4). } \\
\text { Match model includes } \mathrm{Xb} \text { and separate dummy for each job (person-establishment pair). }\end{array}$} \\
\hline
\end{tabular}




\begin{tabular}{|c|c|c|c|c|c|c|}
\hline & \multicolumn{2}{|c|}{$\begin{array}{r}\text { Interval } 1 \\
\end{array}$} & \multicolumn{2}{|c|}{ Interval 4} & \multirow{2}{*}{\multicolumn{2}{|c|}{$\begin{array}{c}\text { Change in Variance } \\
\text { (percent of total change) } \\
\text { (5) }\end{array}$}} \\
\hline & $\begin{array}{c}\text { Var. Component } \\
\text { (1) } \\
\end{array}$ & $\begin{array}{c}\text { Share of Total } \\
\text { (2) } \\
\end{array}$ & $\begin{array}{c}\text { Var. Component } \\
\text { (3) } \\
\end{array}$ & $\begin{array}{c}\text { Share of Total } \\
\text { (4) }\end{array}$ & & \\
\hline Total variance of log wages & 0.137 & 100.0 & 0.249 & 100.0 & 0.112 & 100 \\
\hline \multicolumn{7}{|l|}{ Components of Variance: } \\
\hline Variance of person effect & 0.084 & 61.3 & 0.127 & 51.2 & 0.043 & 39 \\
\hline Variance of establ. effect & 0.025 & 18.5 & 0.053 & 21.2 & 0.027 & 25 \\
\hline Variance of $\mathrm{Xb}$ & 0.015 & 10.7 & 0.007 & 2.8 & -0.008 & -7 \\
\hline Variance of residual & 0.011 & 8.2 & 0.015 & 5.9 & 0.003 & 3 \\
\hline 2cov(person, establ.) & 0.003 & 2.3 & 0.041 & 16.4 & 0.038 & 34 \\
\hline $2 \operatorname{cov}(\mathrm{Xb}$, person+establ.) & -0.001 & -1.0 & 0.006 & 2.4 & 0.007 & 7 \\
\hline \multicolumn{7}{|c|}{ Counterfactuals for Variance of log wages in interval $4:^{* *}$} \\
\hline 1. No rise in correl. of person/estab. effects & 0.137 & & 0.213 & & 0.077 & 69 \\
\hline 2. No rise in var. of estab. effect & 0.137 & & 0.209 & & 0.072 & 64 \\
\hline 3. Both 1 and 2 & 0.137 & & 0.184 & & 0.047 & 42 \\
\hline
\end{tabular}

Notes: See notes to Table 1 for sample composition. Calculations based on estimated AKM models summarized in Table 2.

* First entry is change in variance/variance component from interval 1 to interval 4 . Second entry shows ratio of change in the variance component to the total change in variance of wages in row 1 (as a percentage).

${ }^{* *}$ Counterfactual 1 computes the counterfactual rise in variance assuming the correlation between the person and establishment effects remains at its interval 1 value -- i.e. imposing the restriction that $\operatorname{Cov}_{4}$ (person, establ.) $=\rho_{1} \operatorname{Var}_{4}$ (person) ${ }^{1 / 2} \times \operatorname{Var}_{4}(\text { establ. })^{1 / 2}$ where the 4 subscript refers to the interval 4 value of the statistic and $\rho_{1}$ is the correlation between the person and establishment effects in interval 1 . Counterfactual 2 assumes that the variance of establishment effects remains at its interval 1 level. Counterfactual 3 imposes both of these restrictions. 
Table 4: Decomposition of Changes in Relative Wages by Education Level, 1985-1991 vs 2002-2009

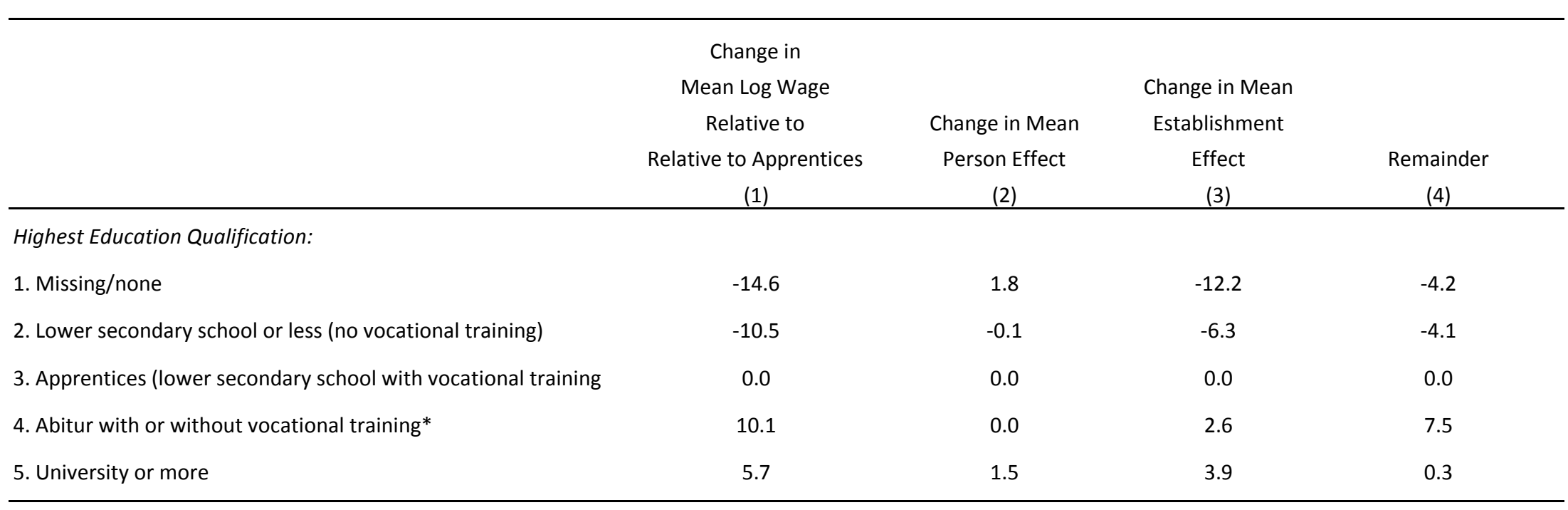

Notes: Wage changes are measured between intervals 1 (1985-1991) and 4 (2002-2009). Remainder (column 4) represents changing relative contribution of Xb component.

*Abitur refers to "Allgemeine Hochshulreife", a certificate of completion of advanced level high school. 
Table 5: Contribution of Person and Establishment Effects to Wage Variation Across Occupations and Industries

\begin{tabular}{|c|c|c|c|c|c|c|}
\hline & \multirow{2}{*}{$\begin{array}{c}\text { Interval } 1 \\
\text { 1985-1991 } \\
(1) \\
\end{array}$} & \multirow{2}{*}{$\begin{array}{c}\text { Interval } 2 \\
1990-1996 \\
(2) \\
\end{array}$} & \multirow{2}{*}{$\begin{array}{c}\text { Interval } 3 \\
1996-2002 \\
(3)\end{array}$} & \multirow{2}{*}{$\begin{array}{c}\text { Interval } 4 \\
2002-2009 \\
(4)\end{array}$} & \multicolumn{2}{|c|}{$\begin{array}{l}\text { Change in } \\
\text { Variance (Int. } 1 \text { to } \operatorname{lnt} 4)^{*}\end{array}$} \\
\hline & & & & & $\begin{array}{c}\text { Change } \\
(5) \\
\end{array}$ & $\begin{array}{c}\text { Share } \\
(6)\end{array}$ \\
\hline \multicolumn{7}{|c|}{ Panel A: Between Occupations (342 3-digit occupations) } \\
\hline Std. dev. of mean log wages & 0.217 & 0.221 & 0.246 & 0.279 & 0.031 & 100 \\
\hline Std. dev. of mean person effects & 0.183 & 0.195 & 0.195 & 0.207 & 0.009 & 31 \\
\hline Std. dev. of mean estbl. effects & 0.089 & 0.094 & 0.102 & 0.126 & 0.008 & 26 \\
\hline $\begin{array}{l}\text { Correlation of mean person effects } \\
\text { and establ. effects }\end{array}$ & 0.082 & 0.111 & 0.284 & 0.296 & 0.013 & 42 \\
\hline \multicolumn{7}{|c|}{ Panel B: Between Industries (96 2-digit industries) } \\
\hline Std. dev. of mean log wages & 0.173 & 0.184 & 0.203 & 0.224 & 0.020 & 100 \\
\hline Std. dev. of mean person effects & 0.103 & 0.114 & 0.128 & 0.140 & 0.009 & 44 \\
\hline Std. dev. of mean estbl. effects & 0.104 & 0.110 & 0.108 & 0.121 & 0.004 & 19 \\
\hline $\begin{array}{l}\text { Correlation of mean person effects } \\
\text { and establ. effects }\end{array}$ & 0.242 & 0.301 & 0.422 & 0.403 & 0.008 & 42 \\
\hline
\end{tabular}

Notes: decompositions based on estimated AKM models summarized in Table 2. Individuals are assigned one occupation per interval; establishments are assigned one industry per interval (see Appendix).

*Entry in column 5 represents change in variance or covariance component. Entry in column 6 is the share of the total change in variance explained. Shares do not add to $100 \%$ because $\mathrm{Xb}$ component and its covariances are omitted. 
Appendix Figure 1: Establishment Size Distributions

Panel A: Overall Distribution

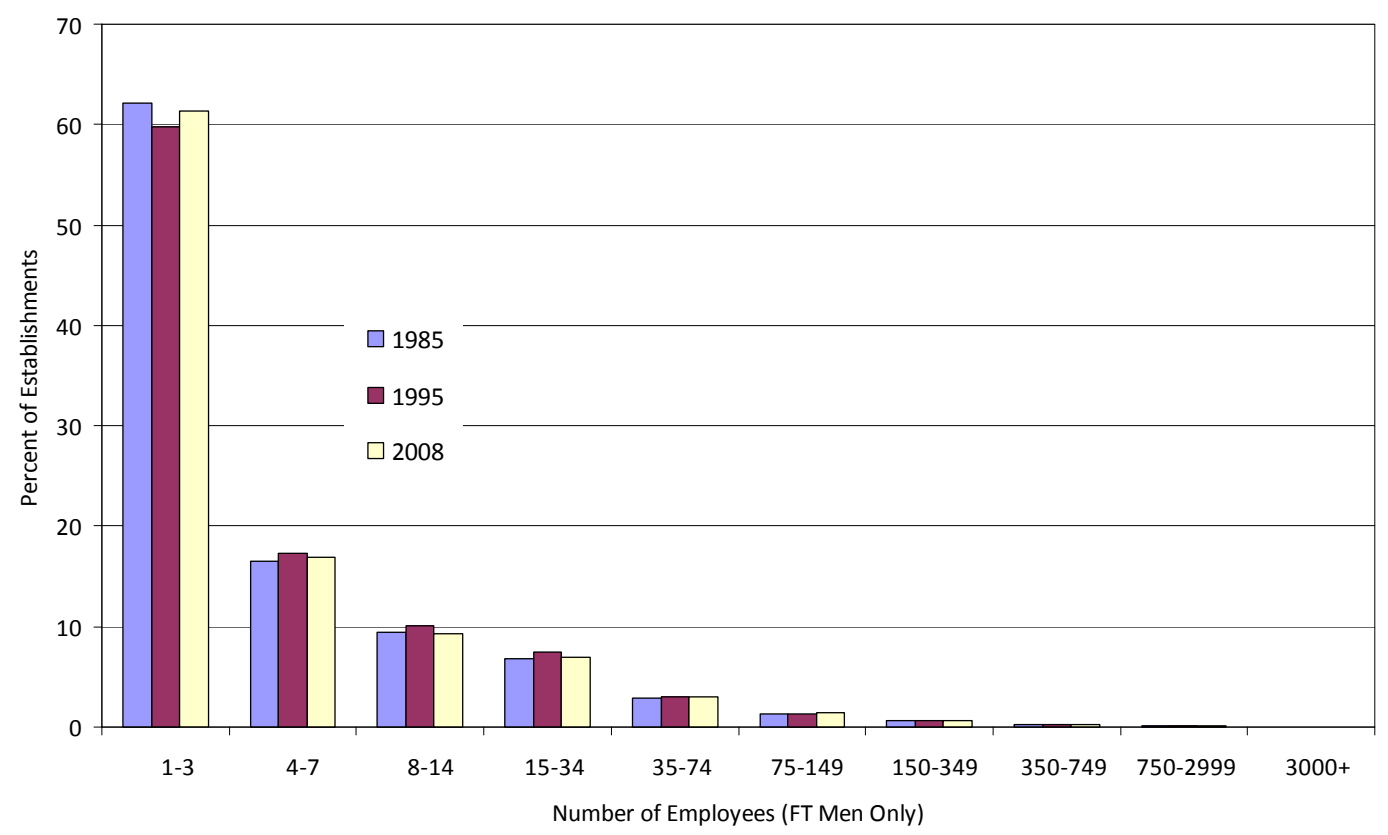

Notes: figure shows size distribution of establishments in years indicated. Employment counts include full time men only.

Panel B: Upper Tail Only

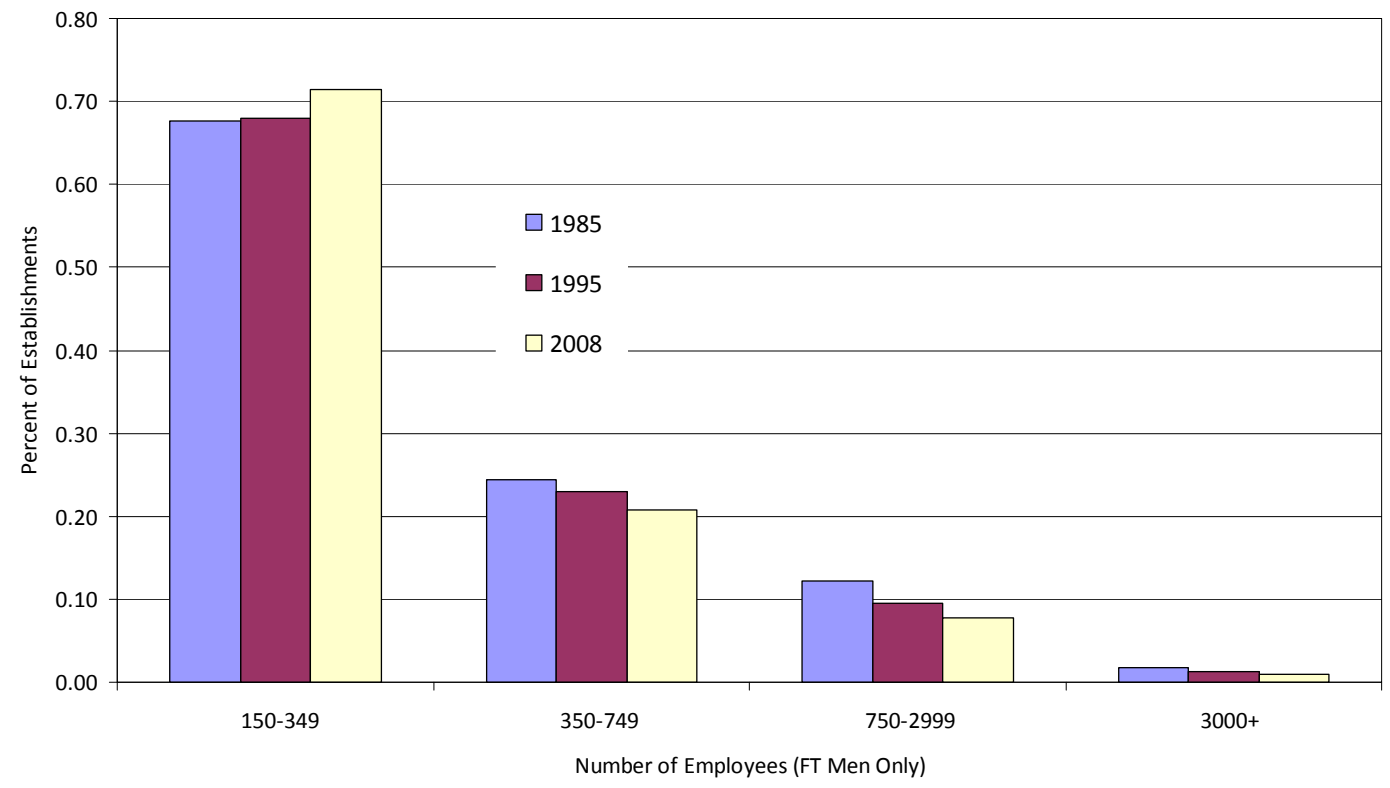

Notes: figure shows conditional size distribution of establishments in years indicated, among establishments with 150 or more full time male workers. Employment counts include full time men only. 
Appendix Figure 2: Censoring of Wages and Gaps Between Imputed and Censored Series

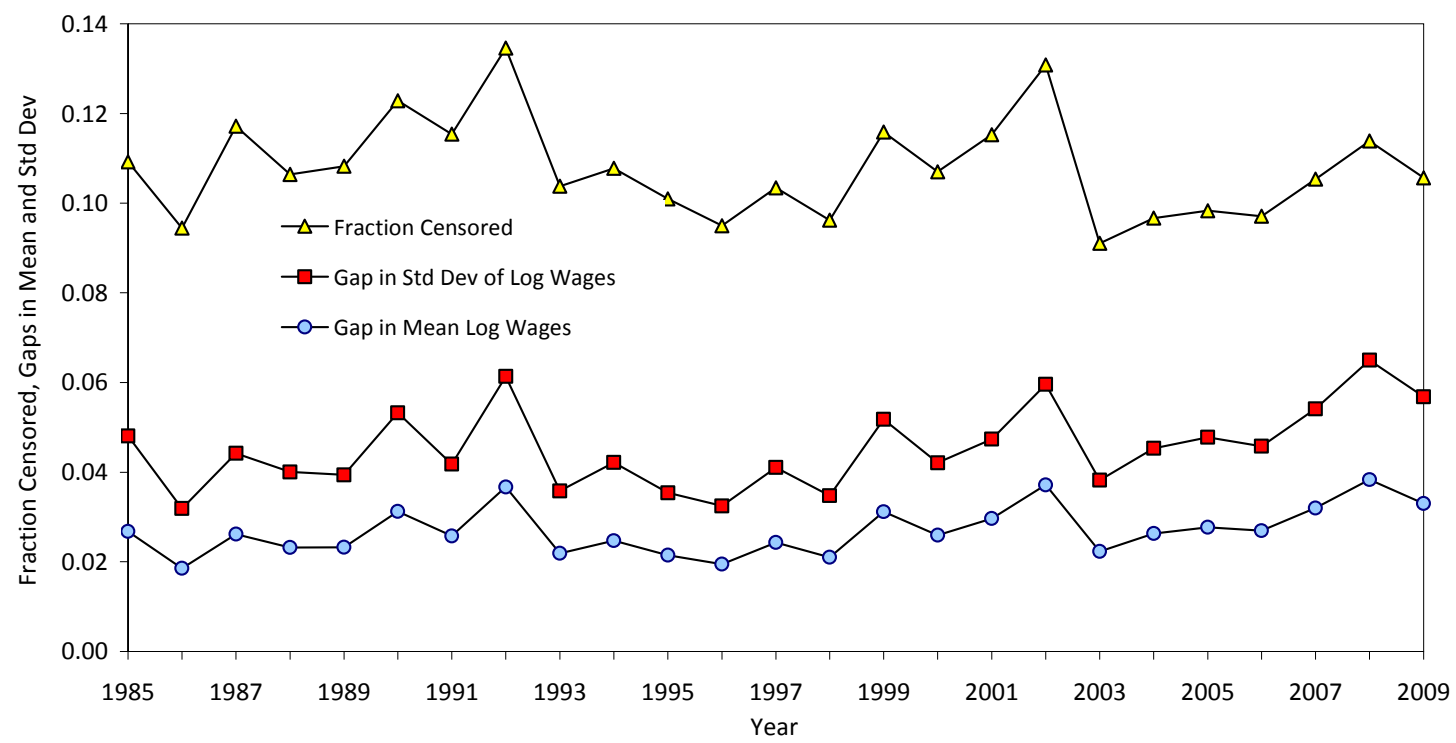

Notes: figure shows fraction of wage observations censored in each year (plotted with yellow triangles) as well as the gap between the standard deviation (red squares) or mean of log real wages (blue circles) between samples in which censored upper tail of wages has been imputed using flexible Tobit models, and sample with no correction for censoring. Wages refer to mean daily wages for full time male workers on the main job in each calendar year.

Appendix Figure 3: Wage Inequality Trends for Males versus Female; Full Time Workers versus All

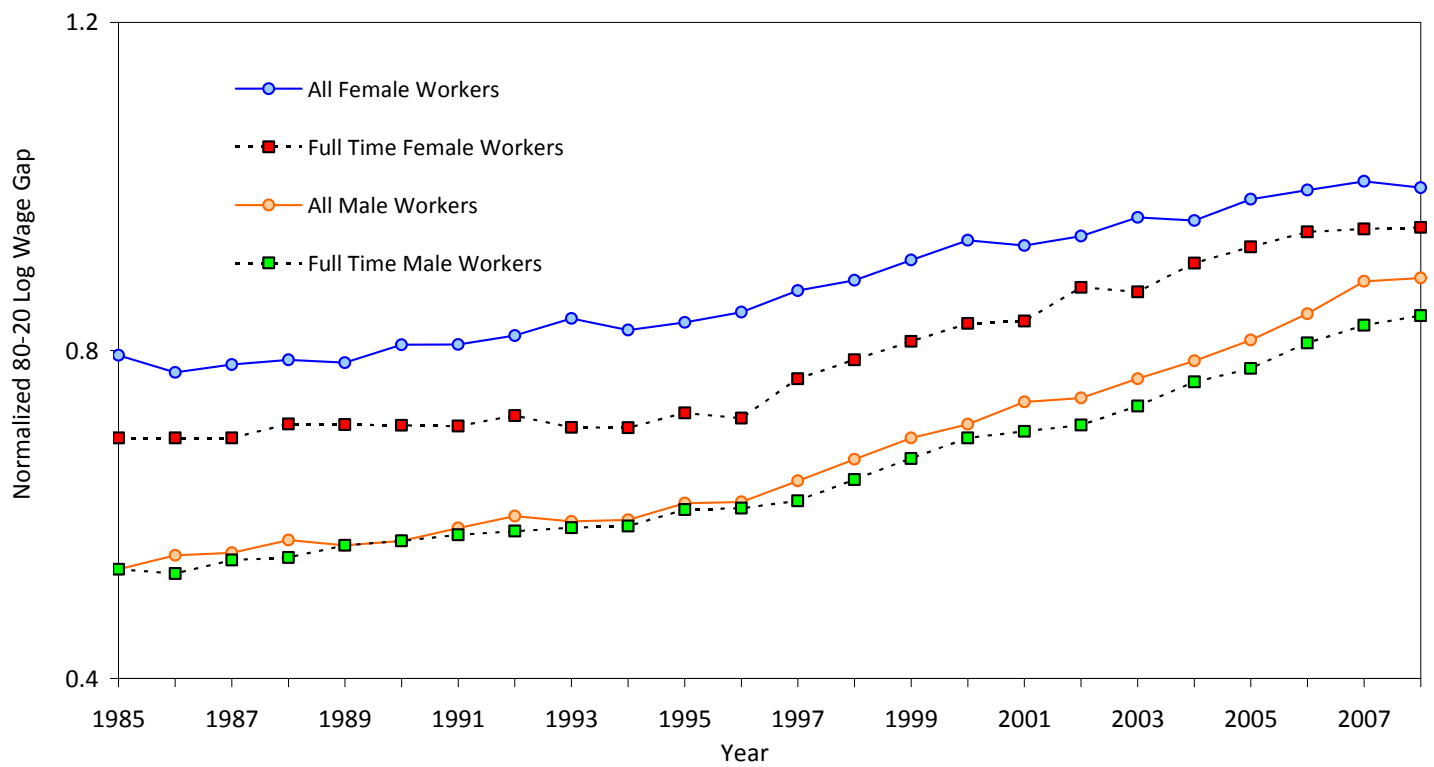

Notes: based on tabulations of SIAB. Measured wage is average daily wage in job with highest total earnings in the year. Wage gap is the difference between the 80th percentile of log real wages and the 20th percentile, divided by 80-20 gap for a standard normal variate. 
Appendix Table 1a: Job Spells and Main Jobs in IEB Data Base

\begin{tabular}{lccc}
\hline & 1985 & 1997 & 2009 \\
\hline $\begin{array}{l}\text { 1. Number of Full Time Job Spells } \\
\text { (men age 20-60, non-marginal jobs) }\end{array}$ & $13,987,548$ & $14,919,079$ & $14,911,559$ \\
$\begin{array}{l}\text { 2. Number of unique person-firm- } \\
\text { year observations }\end{array}$ & $13,181,917$ & $13,968,286$ & $13,456,305$ \\
$\begin{array}{l}\text { 3. Number of person-year observations } \\
\text { (highest-paying job only) }\end{array}$ & $11,980,159$ & $12,661,995$ & $12,104,223$ \\
$\begin{array}{l}\text { 4. Average number of spells per } \\
\text { job in year }\end{array}$ & 1.06 & 1.07 & 1.11 \\
& & & 1.11 \\
\hline
\end{tabular}

Notes: each "job spell" represents a notification of employment in the IEB data base. The entry in row 1 is the number of such notifications for full time, non-marginal jobs held by men age 20-60. Row 2 shows the number of unique person-firm-year observations after collapsing multiple spells at the same employer in the same year. Row 3 shows the number of person observations after selecting the person-firm-year observation with the highest total earnings in the year as the "main job" in a given year. Row 4 gives the ratio of row 1 to row 2 . Row 5 gives the ratio of row 2 to row 3 . 
Appendix Table 1b: Basic Summary Statistics for IAB Sample

\begin{tabular}{|c|c|c|c|c|c|c|}
\hline & \multirow[b]{2}{*}{ Number Observations } & \multirow{2}{*}{$\begin{array}{l}\text { Annual Earnings } \\
\text { (real Euros) }\end{array}$} & \multicolumn{2}{|c|}{ Daily Wage (real Euro/day) } & \multicolumn{2}{|c|}{ Log Real Daily Wage } \\
\hline & & & Mean & Std. Dev & Mean & Std. Dev \\
\hline 1985 & $11,980,159$ & 24,088 & 72.56 & 23.13 & 4.221 & 0.387 \\
\hline 1986 & $12,275,222$ & 25,092 & 75.24 & 24.45 & 4.255 & 0.396 \\
\hline 1987 & $12,360,859$ & 25,793 & 76.92 & 24.89 & 4.277 & 0.398 \\
\hline 1988 & $12,467,192$ & 26,403 & 78.19 & 25.93 & 4.291 & 0.404 \\
\hline 1989 & $12,715,727$ & 26,506 & 78.28 & 25.81 & 4.293 & 0.401 \\
\hline 1990 & $13,289,988$ & 26,967 & 79.72 & 26.02 & 4.312 & 0.398 \\
\hline 1991 & $13,688,681$ & 26,750 & 80.92 & 26.18 & 4.327 & 0.397 \\
\hline 1992 & $13,991,600$ & 27,052 & 81.12 & 26.33 & 4.329 & 0.398 \\
\hline 1993 & $13,643,435$ & 27,481 & 81.41 & 27.26 & 4.330 & 0.405 \\
\hline 1994 & $13,248,077$ & 27,002 & 81.22 & 27.95 & 4.325 & 0.412 \\
\hline 1995 & $13,101,809$ & 27,874 & 82.56 & 28.56 & 4.340 & 0.415 \\
\hline 1996 & $12,813,804$ & 27,251 & 82.42 & 29.02 & 4.335 & 0.423 \\
\hline 1997 & $12,661,995$ & 26,813 & 81.42 & 29.56 & 4.318 & 0.438 \\
\hline 1998 & $12,677,201$ & 27,271 & 82.29 & 30.59 & 4.325 & 0.448 \\
\hline 1999 & $12,719,922$ & 27,259 & 82.94 & 31.26 & 4.329 & 0.458 \\
\hline 2000 & $12,930,046$ & 27,388 & 82.95 & 31.60 & 4.327 & 0.464 \\
\hline 2001 & $12,906,292$ & 27,398 & 82.89 & 31.75 & 4.325 & 0.469 \\
\hline 2002 & $12,610,572$ & 27,425 & 82.86 & 31.89 & 4.323 & 0.475 \\
\hline 2003 & $12,336,685$ & 28,222 & 84.95 & 35.57 & 4.335 & 0.501 \\
\hline 2004 & $12,083,070$ & 28,100 & 84.01 & 35.73 & 4.320 & 0.510 \\
\hline 2005 & $11,857,526$ & 27,960 & 83.47 & 36.07 & 4.310 & 0.519 \\
\hline 2006 & $11,977,347$ & 27,642 & 82.73 & 36.44 & 4.297 & 0.528 \\
\hline 2007 & $12,222,754$ & 27,255 & 81.68 & 36.12 & 4.282 & 0.533 \\
\hline 2008 & $12,323,655$ & 27,169 & 80.99 & 35.72 & 4.274 & 0.533 \\
\hline 2009 & $12,104,223$ & 27,179 & 81.35 & 36.23 & 4.277 & 0.535 \\
\hline
\end{tabular}

Notes: sample includes men in West Germany age 20-60, working full time in non-marginal jobs. Earnings data for each person is based on earnings for the year at the employer who paid the most in that year. Individuals who earned less than 10 euros per day are excluded. Daily wage is censored at Social Security maximum for the corresponding year (total earnings are likewise censored). 
Appendix Table 2: Tobit Models for Apprentices, Age 40-49 in Selected Years

\begin{tabular}{|c|c|c|c|}
\hline & 1985 & 1997 & 2009 \\
\hline \multicolumn{4}{|l|}{ Moments of Unadjusted Log Wage Data: } \\
\hline Mean & 4.382 & 4.4612 & 4.434 \\
\hline Std. Deviation & 0.2677 & 0.3104 & 0.3563 \\
\hline Fraction Censored & 0.155 & 0.107 & 0.0726 \\
\hline \multicolumn{4}{|l|}{ Parameter Estimates from Tobit model: } \\
\hline \multirow[t]{2}{*}{ Intercept } & 0.539 & -0.108 & -0.194 \\
\hline & $(0.030)$ & $(0.020)$ & $(0.003)$ \\
\hline \multirow[t]{2}{*}{ Age/10 } & 0.026 & -0.009 & -0.103 \\
\hline & $(0.002)$ & $(0.002)$ & $(0.003)$ \\
\hline \multirow{2}{*}{$\begin{array}{l}\text { Fraction of person's other wage } \\
\text { observations censored }\end{array}$} & 0.268 & 0.270 & 0.699 \\
\hline & $(0.003)$ & $(0.005)$ & $(0.011)$ \\
\hline \multirow{2}{*}{$\begin{array}{l}\text { Mean of log wage for person } \\
\text { in other years }\end{array}$} & 0.693 & 0.909 & 0.819 \\
\hline & $(0.003)$ & $(0.003)$ & $(0.004)$ \\
\hline \multirow[t]{2}{*}{ Dummy for firm size $>10$} & -0.006 & -0.006 & 0.005 \\
\hline & $(0.002)$ & $(0.002)$ & $(0.002)$ \\
\hline \multirow{2}{*}{$\begin{array}{l}\text { Fraction of workers at firm with } \\
\text { university degree }\end{array}$} & -0.045 & -0.013 & 0.007 \\
\hline & $(0.012)$ & (0.011) & $(0.014)$ \\
\hline \multirow{2}{*}{$\begin{array}{l}\text { Mean years of schooling of workers } \\
\text { at firm }\end{array}$} & -0.014 & -0.010 & -0.007 \\
\hline & $(0.002)$ & (0.002) & (0.002) \\
\hline \multirow{2}{*}{$\begin{array}{l}\text { Fraction of co-workers with } \\
\text { censored wage }^{* *}\end{array}$} & 0.093 & 0.000 & 0.135 \\
\hline & $(0.007)$ & (0.007) & $(0.010)$ \\
\hline \multirow[t]{2}{*}{ Mean log wage of co-workers ${ }^{* *}$} & 0.187 & 0.163 & 0.374 \\
\hline & (0.004) & (0.004) & $(0.004)$ \\
\hline \multirow{2}{*}{$\begin{array}{l}\text { Dummy if person observed in } \\
\text { only } 1 \text { year }\end{array}$} & -0.398 & -0.935 & -0.808 \\
\hline & $(0.005)$ & (0.013) & $(0.016)$ \\
\hline $\begin{array}{l}\text { Dummy if firm has only } 1 \\
\text { worker }\end{array}$ & $\begin{array}{l}-0.223 \\
(0.005)\end{array}$ & $\begin{array}{l}-0.178 \\
(0.005)\end{array}$ & $\begin{array}{c}-0.386 \\
(0.006)\end{array}$ \\
\hline Estimated scale parameter & $\begin{array}{c}0.147 \\
(0.001)\end{array}$ & $\begin{array}{c}0.135 \\
(0.001)\end{array}$ & $\begin{array}{c}0.195 \\
(0.001)\end{array}$ \\
\hline Sample size & 62,889 & 58,392 & 65,904 \\
\hline
\end{tabular}

Notes: standard errors in parentheses. Table entries are coefficient estimates from Tobit models fit to log real daily wages, with censoring at the Social Security maximum contribution rate. Models also include firm size (number of current-year full time male employees) and its square.

${ }^{*}$ Characteristics of full-time male (non-marginal) employees at the same firm.

**Statistic is calculated for full-time male employees at the same firm, excluding the individual of interest. For employers with one firm, statistic is set to mean. 
Appendix Table 3: Mean Log Wages Before and After Job Change, for Movers with Two or More Years of Wage Data Before and After Job Change

\begin{tabular}{|c|c|c|c|c|c|c|c|}
\hline \multirow[b]{3}{*}{$\begin{array}{c}\text { Origin/destination } \\
\text { quartile }^{*}\end{array}$} & \multirow{3}{*}{$\begin{array}{c}\text { Number of } \\
\text { Changes: } \\
(1)\end{array}$} & \multicolumn{4}{|c|}{ Mean Log Wages of Movers } & \multirow{2}{*}{\multicolumn{2}{|c|}{4 Year Change }} \\
\hline & & 2 years & 1 year & 1 year & 2 years & & \\
\hline & & $\begin{array}{c}\text { before } \\
(2)\end{array}$ & $\begin{array}{c}\text { before } \\
\text { (3) }\end{array}$ & $\begin{array}{l}\text { after } \\
(4) \\
\end{array}$ & $\begin{array}{c}\text { after } \\
(5) \\
\end{array}$ & $\begin{array}{l}\text { Raw } \\
(6) \\
\end{array}$ & $\begin{array}{c}\text { Adjusted }^{* *} \\
(7) \\
\end{array}$ \\
\hline \multicolumn{8}{|l|}{ Interval 1: 1985-1991 } \\
\hline 1 to 1 & 333,648 & 4.003 & 4.025 & 4.085 & 4.113 & 0.110 & 0.000 \\
\hline 1 to 2 & 206,251 & 4.063 & 4.085 & 4.207 & 4.248 & 0.185 & 0.075 \\
\hline 1 to 3 & 136,119 & 4.064 & 4.087 & 4.271 & 4.323 & 0.260 & 0.150 \\
\hline 1 to 4 & 82,193 & 4.102 & 4.132 & 4.380 & 4.444 & 0.342 & 0.232 \\
\hline 2 to 1 & 125,376 & 4.160 & 4.178 & 4.144 & 4.175 & 0.015 & -0.072 \\
\hline 2 to 2 & 204,787 & 4.229 & 4.251 & 4.286 & 4.316 & 0.087 & 0.000 \\
\hline 2 to 3 & 158,360 & 4.258 & 4.278 & 4.359 & 4.395 & 0.137 & 0.051 \\
\hline 2 to 4 & 86,038 & 4.298 & 4.324 & 4.474 & 4.529 & 0.231 & 0.144 \\
\hline 3 to 1 & 59,334 & 4.245 & 4.261 & 4.163 & 4.194 & -0.051 & -0.153 \\
\hline 3 to 2 & 91,474 & 4.315 & 4.337 & 4.333 & 4.371 & 0.056 & -0.046 \\
\hline 3 to 3 & 173,160 & 4.384 & 4.409 & 4.452 & 4.486 & 0.102 & 0.000 \\
\hline 3 to 4 & 136,569 & 4.460 & 4.487 & 4.594 & 4.635 & 0.175 & 0.073 \\
\hline 4 to 1 & 30,110 & 4.373 & 4.396 & 4.252 & 4.284 & -0.089 & -0.220 \\
\hline 4 to 2 & 41,079 & 4.459 & 4.488 & 4.447 & 4.487 & 0.028 & -0.103 \\
\hline 4 to 3 & 91,177 & 4.552 & 4.584 & 4.596 & 4.633 & 0.080 & -0.051 \\
\hline 4 to 4 & 290,921 & 4.678 & 4.710 & 4.777 & 4.809 & 0.131 & 0.000 \\
\hline \multicolumn{8}{|l|}{ Interval 4: 2002-2009 } \\
\hline 1 to 1 & 541,307 & 3.880 & 3.873 & 3.867 & 3.875 & -0.005 & 0.000 \\
\hline 1 to 2 & 197,982 & 4.018 & 4.017 & 4.165 & 4.182 & 0.164 & 0.054 \\
\hline 1 to 3 & 88,768 & 3.999 & 4.015 & 4.291 & 4.325 & 0.325 & 0.215 \\
\hline 1 to 4 & 49,167 & 4.056 & 4.083 & 4.468 & 4.521 & 0.465 & 0.355 \\
\hline 2 to 1 & 208,184 & 4.202 & 4.190 & 4.021 & 4.030 & -0.171 & -0.258 \\
\hline 2 to 2 & 333,219 & 4.315 & 4.309 & 4.305 & 4.309 & -0.007 & 0.000 \\
\hline 2 to 3 & 137,528 & 4.381 & 4.377 & 4.437 & 4.456 & 0.075 & -0.012 \\
\hline 2 to 4 & 59,080 & 4.473 & 4.479 & 4.625 & 4.673 & 0.200 & 0.114 \\
\hline 3 to 1 & 73,218 & 4.338 & 4.333 & 4.024 & 4.042 & -0.296 & -0.398 \\
\hline 3 to 2 & 133,606 & 4.456 & 4.458 & 4.390 & 4.401 & -0.055 & -0.157 \\
\hline 3 to 3 & 275,521 & 4.550 & 4.552 & 4.563 & 4.568 & 0.018 & 0.000 \\
\hline 3 to 4 & 150,989 & 4.678 & 4.690 & 4.768 & 4.805 & 0.127 & 0.025 \\
\hline 4 to 1 & 32,664 & 4.518 & 4.526 & 4.139 & 4.167 & -0.351 & -0.482 \\
\hline 4 to 2 & 47,193 & 4.655 & 4.671 & 4.534 & 4.560 & -0.095 & -0.226 \\
\hline 4 to 3 & 127,276 & 4.744 & 4.763 & 4.721 & 4.749 & 0.005 & -0.126 \\
\hline 4 to 4 & 546,855 & 4.937 & 4.957 & 4.973 & 5.021 & 0.083 & 0.000 \\
\hline
\end{tabular}

Notes: entries are mean log real daily wages for job changers who are observed with at least 2 years of data prior to a job change, and two years after.

*Quartiles are based on mean wages of co-workers at old job in year prior to move, and in new job in year after move.

${ }^{* *}$ Four year wage change for origin-destination group minus change for job changers who remain in same quartile. 
Appendix Table 4: Estimation Results for AKM Model, Fit by Interval for Apprentices Only

\begin{tabular}{|c|c|c|c|c|c|}
\hline & $\begin{array}{c}\text { Interval } 1 \\
1985-1991 \\
(1)\end{array}$ & $\begin{array}{c}\text { Interval } 2 \\
1990-1996 \\
(2)\end{array}$ & $\begin{array}{c}\text { Interval } 3 \\
1996-2002 \\
(3)\end{array}$ & $\begin{array}{c}\text { Interval } 4 \\
2002-2009 \\
(4)\end{array}$ & $\begin{array}{c}\text { Ratio: } \\
\text { int. 4/int. } 1 \\
(5)\end{array}$ \\
\hline \multicolumn{6}{|l|}{ Person and Establishment Parameters: } \\
\hline Number person effects & $10,128,342$ & $10,346,742$ & $9,288,956$ & $8,145,059$ & \\
\hline Number establishment effects & $1,008,959$ & $1,078,911$ & $1,093,438$ & 990,608 & \\
\hline \multicolumn{6}{|l|}{ Summary of Parameter Estimates: } \\
\hline Std. dev. of person effects & 0.241 & 0.249 & 0.271 & 0.285 & 1.19 \\
\hline Std. dev. of establ. effects & 0.152 & 0.159 & 0.170 & 0.202 & 1.33 \\
\hline Std. dev. of Xb & 0.121 & 0.080 & 0.073 & 0.064 & 0.53 \\
\hline $\begin{array}{l}\text { Correlation of person/est effects } \\
\text { (across person-year obs.) }\end{array}$ & -0.035 & 0.008 & 0.048 & 0.098 & \\
\hline $\begin{array}{l}\text { Correlation of person effects/Xb } \\
\text { (across person-year obs.) }\end{array}$ & 0.050 & 0.075 & -0.029 & 0.020 & \\
\hline $\begin{array}{l}\text { Correlation of establ. effects/Xb } \\
\text { (across person-year obs.) }\end{array}$ & 0.064 & 0.064 & 0.048 & 0.082 & \\
\hline RMSE of AKM residual & 0.110 & 0.109 & 0.110 & 0.110 & 1.00 \\
\hline Adjusted R-squared & 0.887 & 0.891 & 0.901 & 0.919 & \\
\hline \multicolumn{6}{|l|}{ Comparison Match Model } \\
\hline RMSE of Match model & 0.096 & 0.095 & 0.094 & 0.094 & 0.99 \\
\hline Std. Dev of Match Effect ${ }^{*}$ & 0.054 & 0.052 & 0.056 & 0.057 & 1.04 \\
\hline Std. Dev. Log Wages & 0.328 & 0.329 & 0.349 & 0.388 & 1.18 \\
\hline Sample size & $54,993,845$ & $56,701,812$ & $51,031,280$ & $50,700,611$ & \\
\hline
\end{tabular}

Notes: see notes to Table 2. Models reported here are estimated for subsample of workers with apprenticeship training only. $\mathrm{Xb}$ includes year dummies and quadratic and cubic terms in age (total of 8 parameters in intervals 1-3, 9 in interval 4). Match model includes $\mathrm{Xb}$ and separate dummy for each job (person-establishment pair).

* Standard deviation of match effect estimated as square root of difference in mean squared errors between AKM model and match effect model. 
Appendix Table 5: Decompositions of Rise in Wage Inequality for Apprentices

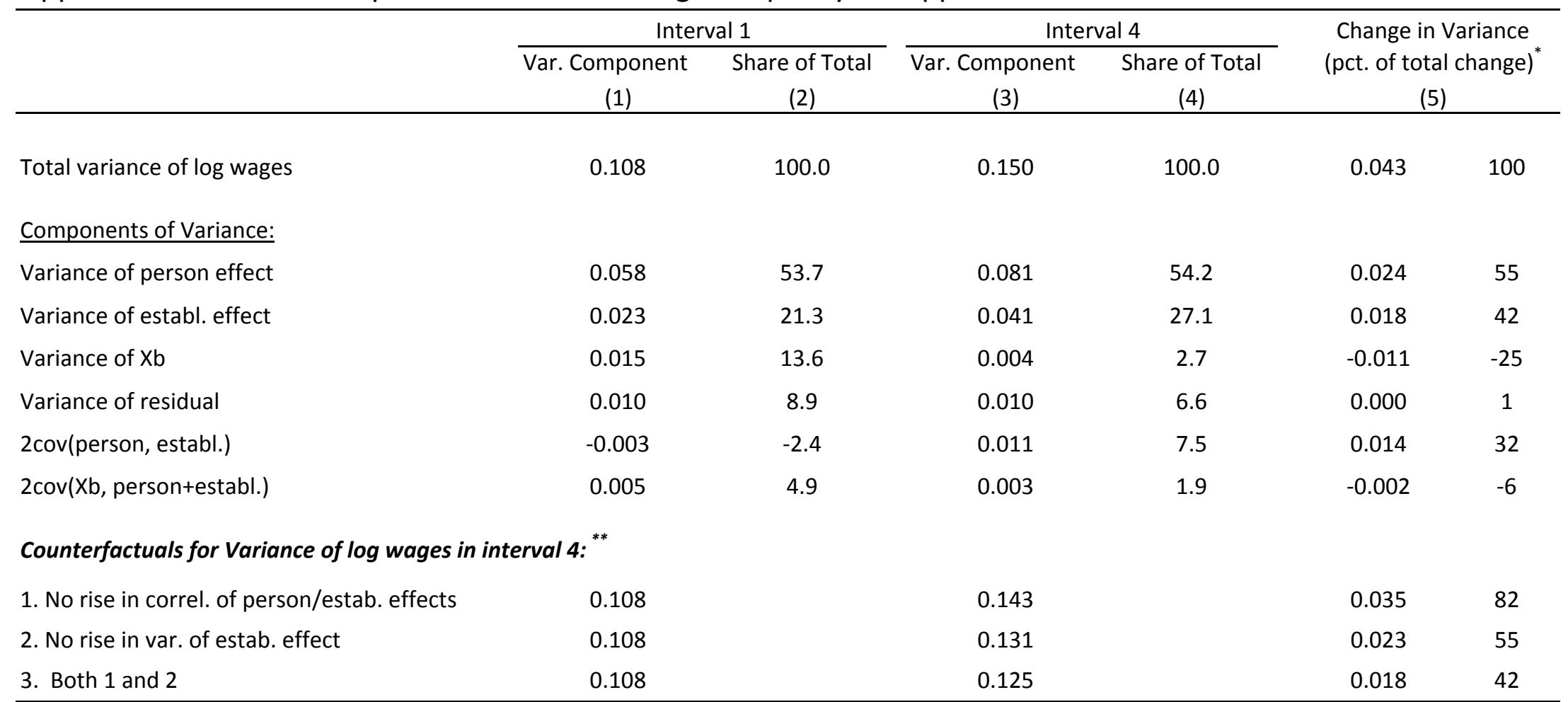

Notes: see notes to Table 3. Calculations based on estimated AKM models summarized in Appendix Table 4.

"First entry is change in variance/variance component from interval 1 to interval 4 . Second entry shows ratio of change in the variance component to the total change in variance of wages in row 1 (as a percent).

${ }^{* *}$ Counterfactual 1 computes the counterfactual rise in variance assuming the correlation between the person and establishment effects remains at its interval 1 value -- i.e. imposing the restriction that $\operatorname{Cov}_{4}$ (person, establ.) $=\rho_{1} \operatorname{Var}_{4}(\text { person })^{1 / 2} \times \operatorname{Var}_{4}(\text { establ. })^{1 / 2}$ where subscript 4 refers to the interval 4 value of the statistic and and $\rho_{1}$ is the correlation between the person and establishment effects in interval 1 . Counterfactual 2 assumes that the variance of establishment effects remains at its interval 1 level. Counterfactual 3 imposes both of these restrictions. 


\section{Appendix Table 6: Number and Chararacteristics of New Establishments}

\begin{tabular}{|c|c|c|c|c|c|c|c|c|c|c|c|}
\hline \multirow{3}{*}{$\begin{array}{c}\text { First Year } \\
\text { in IAB } \\
(1)\end{array}$} & \multirow[b]{3}{*}{$\begin{array}{c}\text { Number } \\
(2)\end{array}$} & \multirow{2}{*}{\multicolumn{2}{|c|}{ Employment (FT Men) }} & \multicolumn{2}{|c|}{ Pct. of Establishments: } & & & & & & \\
\hline & & & & \multirow{2}{*}{$\begin{array}{c}\text { Always } \\
1 \text { worker } \\
(5)\end{array}$} & \multirow{2}{*}{$\begin{array}{c}\text { Always } \\
>3 \text { workers } \\
(6)\end{array}$} & \multicolumn{2}{|c|}{ Log Real Wage } & \multicolumn{2}{|c|}{ Residual Wage } & \multicolumn{2}{|c|}{ Human Capital Index } \\
\hline & & $\begin{array}{c}\text { Mean } \\
(3)\end{array}$ & $\begin{array}{c}\text { Std Dev } \\
(4)\end{array}$ & & & $\begin{array}{c}\text { Mean } \\
(7)\end{array}$ & $\begin{array}{c}\text { Std Dev } \\
(8)\end{array}$ & $\begin{array}{c}\text { Mean } \\
(9)\end{array}$ & $\begin{array}{r}\text { Std Dev } \\
(10)\end{array}$ & $\begin{array}{r}\text { Mean } \\
(11)\end{array}$ & $\begin{array}{r}\text { Std Dev } \\
(12)\end{array}$ \\
\hline 1985 & 951,170 & 12.4 & 123.7 & 22.4 & 26.3 & 4.044 & 0.443 & -0.224 & 0.373 & 1.010 & 0.222 \\
\hline 1986 & 122,770 & 3.3 & 11.7 & 43.7 & 7.4 & 3.848 & 0.539 & -0.370 & 0.454 & 0.998 & 0.302 \\
\hline 1987 & 98,037 & 3.7 & 17.1 & 42.9 & 8.4 & 3.848 & 0.534 & -0.376 & 0.457 & 0.999 & 0.293 \\
\hline 1988 & 95,999 & 3.9 & 20.5 & 42.1 & 9.0 & 3.862 & 0.531 & -0.376 & 0.461 & 1.002 & 0.279 \\
\hline 1989 & 94,434 & 4.2 & 23.7 & 41.0 & 9.8 & 3.900 & 0.526 & -0.355 & 0.456 & 1.007 & 0.271 \\
\hline 1990 & 103,813 & 4.2 & 18.9 & 40.5 & 10.1 & 3.910 & 0.519 & -0.358 & 0.457 & 1.009 & 0.263 \\
\hline 1991 & 105,670 & 4.0 & 19.4 & 41.0 & 10.3 & 3.902 & 0.520 & -0.369 & 0.468 & 1.010 & 0.259 \\
\hline 1992 & 117,003 & 5.0 & 26.2 & 38.3 & 12.8 & 3.917 & 0.500 & -0.366 & 0.443 & 1.013 & 0.265 \\
\hline 1993 & 107,323 & 4.3 & 29.1 & 40.1 & 11.7 & 3.909 & 0.513 & -0.353 & 0.451 & 1.008 & 0.261 \\
\hline 1994 & 107,704 & 4.4 & 20.4 & 40.3 & 12.1 & 3.905 & 0.514 & -0.353 & 0.455 & 1.008 & 0.259 \\
\hline 1995 & 109,800 & 4.5 & 26.3 & 40.4 & 11.9 & 3.898 & 0.520 & -0.359 & 0.462 & 1.008 & 0.259 \\
\hline 1997 & 110,277 & 4.7 & 43.2 & 39.6 & 12.9 & 3.857 & 0.536 & -0.375 & 0.481 & 1.003 & 0.260 \\
\hline 1998 & 116,886 & 4.7 & 26.6 & 40.1 & 12.7 & 3.868 & 0.538 & -0.370 & 0.479 & 1.004 & 0.269 \\
\hline 1999 & 127,818 & 4.6 & 25.5 & 40.1 & 13.1 & 3.854 & 0.547 & -0.371 & 0.491 & 1.002 & 0.273 \\
\hline 2000 & 122,357 & 4.6 & 20.7 & 40.7 & 13.7 & 3.861 & 0.562 & -0.354 & 0.499 & 1.000 & 0.282 \\
\hline 2001 & 117,078 & 4.7 & 26.1 & 42.0 & 14.1 & 3.848 & 0.578 & -0.363 & 0.510 & 0.999 & 0.288 \\
\hline 2002 & 110,888 & 4.6 & 32.5 & 43.5 & 13.9 & 3.818 & 0.580 & -0.378 & 0.513 & 0.996 & 0.290 \\
\hline 2003 & 107,526 & 4.5 & 17.1 & 43.5 & 15.1 & 3.800 & 0.585 & -0.381 & 0.514 & 0.994 & 0.296 \\
\hline 2004 & 107,681 & 4.4 & 22.8 & 44.7 & 14.9 & 3.762 & 0.588 & -0.398 & 0.520 & 0.989 & 0.301 \\
\hline 2005 & 103,718 & 4.2 & 19.8 & 45.7 & 14.9 & 3.745 & 0.591 & -0.404 & 0.524 & 0.987 & 0.310 \\
\hline 2006 & 103,802 & 4.1 & 19.4 & 47.4 & 15.1 & 3.734 & 0.591 & -0.401 & 0.521 & 0.984 & 0.317 \\
\hline 2007 & 106,549 & 4.0 & 17.3 & 50.5 & 15.9 & 3.711 & 0.626 & -0.416 & 0.553 & 0.982 & 0.326 \\
\hline 2008 & 98,890 & 3.6 & 20.5 & 55.0 & 17.1 & 3.730 & 0.620 & -0.392 & 0.538 & 0.981 & 0.341 \\
\hline
\end{tabular}

Notes: employment and wage data pertain to full time non-marginal male workers only. Residual wage (columns 9-10) is wage, deviated from prediction from a standard Mincer-type model fit separately by year. Human capital index (columns 11-12) is predicted wage from a standard Mincer-type model fit to all sample years (index is normalized to have value of 1 across all years). 
Appendix Table 7: Probit, OLS and Tobit Models for Establishment Survival

\begin{tabular}{|c|c|c|c|c|}
\hline & $\begin{array}{c}\text { Probit: } \\
\text { Survive } 5 \text { yrs. } \\
\text { (1) }\end{array}$ & $\begin{array}{c}\text { Probit: } \\
\text { Survive } 10 \text { yrs. } \\
(2)\end{array}$ & $\begin{array}{c}\text { OLS } \\
\text { Survival Time } \\
(3) \\
\end{array}$ & $\begin{array}{c}\text { Tobit } \\
\text { Suvival Time } \\
(4)\end{array}$ \\
\hline \multicolumn{5}{|c|}{ Panel A: Establishments First Observed 1985-1991 $(n=1,221,098)$} \\
\hline $\begin{array}{l}\text { 1. Establishment } \\
\text { Effect (interval 1) }\end{array}$ & $\begin{array}{c}0.256 \\
(0.004)\end{array}$ & $\begin{array}{c}0.265 \\
(0.004)\end{array}$ & $\begin{array}{c}1.782 \\
(0.023)\end{array}$ & $\begin{array}{c}2.004 \\
(0.030)\end{array}$ \\
\hline 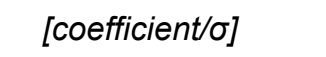 & & & & 0.197 \\
\hline $\begin{array}{l}\text { 2. Mean Person } \\
\text { Effect (interval 1) }\end{array}$ & $\begin{array}{c}0.259 \\
(0.005)\end{array}$ & $\begin{array}{c}0.234 \\
(0.005)\end{array}$ & $\begin{array}{c}1.619 \\
(0.032)\end{array}$ & $\begin{array}{c}1.927 \\
(0.042)\end{array}$ \\
\hline 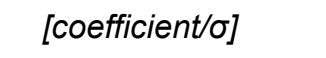 & & & & 0.189 \\
\hline $\begin{array}{l}\text { 3. Standard deviation } \\
\text { of latent time }(\sigma)\end{array}$ & -- & -- & 7.996 & $\begin{array}{l}10.182 \\
(0.008)\end{array}$ \\
\hline Mean of Dep. Var. & 0.674 & 0.521 & & \\
\hline Fraction Censored & -- & -- & & \\
\hline \multicolumn{5}{|c|}{ Panel B: Establishments First Observed 1990-1996 $(n=603,417)$} \\
\hline $\begin{array}{l}\text { 1. Establishment } \\
\text { Effect (interval 2) }\end{array}$ & $\begin{array}{c}0.317 \\
(0.005)\end{array}$ & $\begin{array}{c}0.357 \\
(0.005)\end{array}$ & $\begin{array}{c}1.655 \\
(0.020)\end{array}$ & $\begin{array}{c}2.045 \\
(0.025)\end{array}$ \\
\hline [coefficient/o] & & & & 0.284 \\
\hline $\begin{array}{l}\text { 2. Mean Person } \\
\text { Effect (interval 2) }\end{array}$ & $\begin{array}{c}0.367 \\
(0.006)\end{array}$ & $\begin{array}{c}0.348 \\
(0.007)\end{array}$ & $\begin{array}{c}1.821 \\
(0.029)\end{array}$ & $\begin{array}{c}2.234 \\
(0.036)\end{array}$ \\
\hline 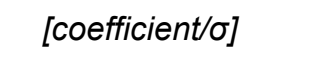 & & & & 0.310 \\
\hline $\begin{array}{l}\text { 3. Standard deviation } \\
\text { of latent time }(\sigma)\end{array}$ & -- & -- & 5.878 & $\begin{array}{c}7.212 \\
(0.008)\end{array}$ \\
\hline Mean of Dep. Var. & 0.495 & 0.326 & & \\
\hline Fraction Censored & -- & -- & & \\
\hline \multicolumn{5}{|c|}{ Panel C: Establishments First Observed 1996-2002 $(n=646,729)$} \\
\hline $\begin{array}{l}\text { 1. Establishment } \\
\text { Effect (interval 3) }\end{array}$ & $\begin{array}{c}0.279 \\
(0.004)\end{array}$ & & $\begin{array}{c}0.895 \\
(0.012)\end{array}$ & $\begin{array}{c}1.245 \\
(0.017)\end{array}$ \\
\hline 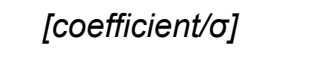 & & & & 0.243 \\
\hline $\begin{array}{l}\text { 2. Mean Person } \\
\text { Effect (interval 3) }\end{array}$ & $\begin{array}{c}0.338 \\
(0.006)\end{array}$ & & $\begin{array}{c}1.126 \\
(0.017)\end{array}$ & $\begin{array}{c}1.543 \\
(0.023)\end{array}$ \\
\hline 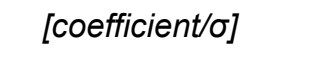 & & & & 0.302 \\
\hline $\begin{array}{l}\text { 3. Standard deviation } \\
\text { of latent time }(\sigma)\end{array}$ & -- & & 3.849 & $\begin{array}{c}5.115 \\
(0.006)\end{array}$ \\
\hline Mean of Dep. Var. & 0.449 & & & \\
\hline Fraction Censored & -- & & & \\
\hline
\end{tabular}

Notes: standard errors in parentheses. All models include additional controls for log of number of employees, mean schooling of employees, and dummies for year first observed in IAB. Sample includes establishments first observed in IEB data with positive male full time employment in years indicated in panel heading. Outcome variable is dummy for surviving 5 or 10 years (columns 1-2), or survival time (columns 3-4). Note that sample in panel $A$ includes 748,192 establishments that were in operation in 1985, and whose duration is left censored. 
Appendix Table 8: Probit, OLS and Tobit Models for Job Survival (Fit to 5\% Sample of Jobs)

\begin{tabular}{|c|c|c|c|c|}
\hline & $\begin{array}{c}\text { Probit: } \\
\text { Survive } 3 \text { yrs. } \\
\text { (1) }\end{array}$ & $\begin{array}{c}\text { Probit: } \\
\text { Survive } 5 \text { yrs. } \\
(2)\end{array}$ & $\begin{array}{c}\text { OLS } \\
\text { Survival Time } \\
(3) \\
\end{array}$ & $\begin{array}{c}\text { Tobit } \\
\text { Suvival Time } \\
(4) \\
\end{array}$ \\
\hline \multicolumn{5}{|c|}{ Panel A: Jobs First Observed 1985-1991 $(n=1,264,498)$} \\
\hline $\begin{array}{l}\text { 1. Establishment } \\
\text { Effect (interval 1) }\end{array}$ & $\begin{array}{c}0.488 \\
(0.008)\end{array}$ & $\begin{array}{c}0.444 \\
(0.008)\end{array}$ & $\begin{array}{c}1.309 \\
(0.034)\end{array}$ & $\begin{array}{l}1.339 \\
(0.037)\end{array}$ \\
\hline 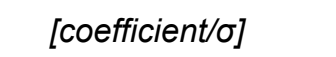 & & & & 0.206 \\
\hline $\begin{array}{l}\text { 2. Person Effect } \\
\text { (interval 1) }\end{array}$ & $\begin{array}{c}0.764 \\
(0.005)\end{array}$ & $\begin{array}{c}0.664 \\
(0.005)\end{array}$ & $\begin{array}{l}2.508 \\
(0.024)\end{array}$ & $\begin{array}{l}2.530 \\
(0.024)\end{array}$ \\
\hline 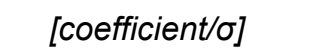 & & & & 0.389 \\
\hline $\begin{array}{l}\text { 3. Standard deviation } \\
\text { of latent time }(\sigma)\end{array}$ & -- & -- & 6.148 & $\begin{array}{l}6.504 \\
(0.004)\end{array}$ \\
\hline Mean of Dep. Var. & 0.505 & 0.389 & & \\
\hline Fraction Censored & -- & -- & & \\
\hline \multicolumn{5}{|c|}{ Panel B: Jobs First Observed 1990-1996 $(n=854,522)$} \\
\hline $\begin{array}{l}\text { 1. Establishment } \\
\text { Effect (interval 2) }\end{array}$ & $\begin{array}{c}0.700 \\
(0.008)\end{array}$ & $\begin{array}{c}0.712 \\
(0.009)\end{array}$ & $\begin{array}{l}1.938 \\
(0.026)\end{array}$ & $\begin{array}{l}2.039 \\
(0.028)\end{array}$ \\
\hline 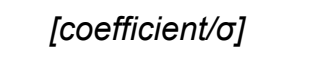 & & & & 0.411 \\
\hline $\begin{array}{l}\text { 2. Person Effect } \\
\text { (interval 2) }\end{array}$ & $\begin{array}{l}0.816 \\
(0.006)\end{array}$ & $\begin{array}{c}0.713 \\
(0.006)\end{array}$ & $\begin{array}{l}2.286 \\
(0.020)\end{array}$ & $\begin{array}{l}2.360 \\
(0.020)\end{array}$ \\
\hline 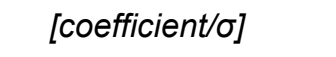 & & & & 0.476 \\
\hline $\begin{array}{l}\text { 3. Standard deviation } \\
\text { of latent time }(\sigma)\end{array}$ & -- & -- & 4.620 & $\begin{array}{l}4.962 \\
(0.004)\end{array}$ \\
\hline Mean of Dep. Var. & 0.358 & 0.247 & & \\
\hline Fraction Censored & -- & -- & & \\
\hline \multicolumn{5}{|c|}{ Panel C: Establishments First Observed 1996-2002 $(n=857,530)$} \\
\hline $\begin{array}{l}\text { 1. Establishment } \\
\text { Effect (interval 3) }\end{array}$ & $\begin{array}{c}0.792 \\
(0.007)\end{array}$ & $\begin{array}{c}0.815 \\
(0.008)\end{array}$ & $\begin{array}{c}1.729 \\
(0.017)\end{array}$ & $\begin{array}{c}1.952 \\
(0.019)\end{array}$ \\
\hline 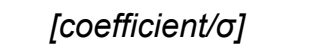 & & & & 0.512 \\
\hline $\begin{array}{l}\text { 2. Person Effect } \\
\text { (interval 2) }\end{array}$ & $\begin{array}{c}0.612 \\
(0.005)\end{array}$ & $\begin{array}{l}0.508 \\
(0.006)\end{array}$ & $\begin{array}{l}1.413 \\
(0.013)\end{array}$ & $\begin{array}{c}1.544 \\
(0.015)\end{array}$ \\
\hline 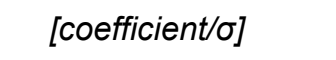 & & & & 0.405 \\
\hline $\begin{array}{l}\text { 3. Standard deviation } \\
\text { of latent time }(\sigma)\end{array}$ & -- & -- & 3.327 & $\begin{array}{l}3.810 \\
(0.003)\end{array}$ \\
\hline Mean of Dep. Var. & 0.344 & 0.241 & & \\
\hline Fraction Censored & -- & -- & & \\
\hline
\end{tabular}

Notes: standard errors in parentheses. All models include additional controls for log of number of employees, dummies for schooling levels of worker, and dummies for job start year. Sample includes jobs first observed in IEB data in years indicated in panel heading. Outcome variable is dummy for job surviving 3 or 5 years (columns 1-2), or survival time (columns 3-4). Note that sample in panel A includes 583,456 jobs that were in progress in 1985 , and whose duration is left censored. 